\title{
LA PUBLICACIÓN DE DATOS DE PROFESORES Y ALUMNOS Y LA PRIVACIDAD PERSONAL. ACERCA DE LA PROTECCIÓN DE DATOS PERSONALES EN LAS UNIVERSIDADES
}

POR

ANTONIO TRONCOSO REIGADA

Profesor titular de Derecho Constitucional

\section{LAS UNIVERSIDADES DESDE LA PERSPECTIVA CONSTITUCIONAL}

El artículo 27.10 de nuestra Constitución «reconoce la autonomía de las Universidades, en los términos que la Ley establezca» ${ }^{1}$. Esta previ-

\footnotetext{
1 Cfr. más ampliamente I. TORRES Muro, La autonomía universitaria. Aspectos constitucionales, CEPC, Madrid, 2005, págs. 29-61; T-R. FERNÁNDEZ, La autonomía universitaria: ámbito y límites, Madrid, Civitas, 1982; A. EMBID IRUJO, "Universidad", Enciclopedia Jurídica Básica, IV, Civitas, Madrid, 1995, págs. 6753-6757; A. FERNÁNDEZMiranda y A. Sánchez Navarro, "Artículo 27. Enseñanza", en O. Alzaga Villamil, Comentarios a la Constitución Española de 1978, Editoriales de Derecho ReunidasCortes Generales, Madrid, 1996, págs. 263-272; J. LEGUINA VILLA, «La autonomía universitaria en la jurisprudencia del Tribunal Constitucional", Estudios sobre la Constitución Española. Homenaje al Profesor E. García de Enterría, II, Civitas, Madrid, 1991, págs. 1199-1212; A. DE AsIs RoIG, "La autonomía universitaria y derechos fundamentales", Anuario de Derechos Humanos, núm. 7, 1990; J. Oliver Araujo, «Alcance y significado de la autonomía universitaria según la doctrina del Tribunal Constitucional», RDP, núm. 33, 1991; J. M. SOUVIRón MorenilLA, La Universidad es-
} 
sión constitucional fue desarrollada inicialmente por la Ley Orgánica 11/1983, de 25 de agosto, de Reforma Universitaria, y en la actualidad por la Ley Orgánica 6/2001, de 21 de diciembre, de Universidades - LOU_ ${ }^{2}$. Las Universidades Públicas son instituciones creadas por los órganos legislativos para desarrollar el servicio público de la educación superior mediante la investigación, la docencia y el estudio. Las Universidades privadas son instituciones creadas por las personas físicas o jurídicas privadas para cumplir esas mismas funciones. Todas las Universidades se rigen por la Ley Orgánica 6/2001, de 21 de diciembre, de Universidades y por las normas que dicten el Estado y las Comunidades Autónomas en el ejercicio de sus competencias. Las Universidades Públicas se rigen, además, por su Ley de creación y por sus Estatutos, aprobados por Decreto del Consejo de Gobierno de la Comunidad Autónoma. Las Universidades Privadas se rigen también por las propias normas de organización y funcionamiento, así como por las normas correspondientes a la personalidad jurídica que adopten -arts. 3 y 6 LOU-.

La legislación ha definido a las Universidades Públicas como Administraciones, de manera que gozan de todas las prerrogativas y potestades de éstas y sus actos son susceptibles de recurso en vía contencioso-administrativa ${ }^{3}$. Los Estatutos de las Universidades Públicas reconocen esta naturaleza jurídico-pública ${ }^{4}$. Así, por ejemplo, el artículo 1 de los Estatutos de la Universidad Complutense de Madrid, aprobados por el Decreto 58/2003, de 8 de mayo, del Consejo de Gobierno de la Comunidad de Madrid define a la Universidad Complutense como «una institución de Derecho Público con personalidad jurídica y patrimonio propio" y señala que "[c]omo Administración Pública vinculada a la de la Comunidad de Madrid, la Universidad Complutense de Madrid goza de todas las prerrogativas y potestades propias de aquéIlas $»^{5}$. En cambio, las Universidades Privadas no tienen el carácter de

pañola. Claves de su definición y régimen jurídico institucional, Universidad de Valladolid, Valladolid, 1988.

2 El Gobierno ha enviado a las Cortes Generales un proyecto de ley de reforma de la Ley Orgánica 6/2001, de 21 de diciembre, de Universidades.

${ }^{3}$ Cfr. también SSTS de 26 de octubre de 2000 y de 22 de octubre de 1999.

${ }^{4}$ Cfr. STC 75/1997, de 21 de marzo, sobre el carácter de los Estatutos de las Universidades.

${ }^{5}$ Los Estatutos de la Universidad Autónoma de Madrid, aprobados por el Decreto 214/2003, de 16 de octubre, del Consejo de Gobierno de la Comunidad de Madrid, señalan en su artículo 1 al definir su naturaleza que "[l]a Universidad Autónoma de Madrid es una Entidad de Derecho Público a la que corresponde, en el ámbito de sus competencias, el servicio público de la educación superior mediante 
Administración Pública, sin perjuicio de las facultades de control que corresponden en este ámbito a las Comunidades Autónomas.

Las Universidades son entidades que tienen como rasgo constitucional su autonomía ${ }^{6}$. La Sentencia del Tribunal Constitucional 26/1987, de 27 de febrero, define la autonomía universitaria como un derecho fundamental de la comunidad universitaria - frente a la posición tal vez más adecuada que la consideraba una garantía institucional ${ }^{7}$-, en virtud de su ubicación en la Sección Primera del Capítulo II del Título I de la Constitución, del sentido gramatical —su "reconocimiento"- y desde la posición teleológica de entender que ésta tendría su fundamento en la libertad académica de la que la autonomía universitaria sería su vertiente objetiva o institucional ${ }^{8}$. En todo caso, la autonomía universitaria, entendida como parte del contenido esencial de la libertad aca-

la investigación, la docencia y el estudio". Igualmente, el artículo 126 señala que "[l]a Universidad Autónoma de Madrid, en su calidad de Administración Pública y dentro de la esfera de sus competencias, ostenta las prerrogativas y potestades propias de la Administración". Los Estatutos de la Universidad Politécnica de Madrid, aprobados por el Decreto 215/2003, de 16 de octubre, del Consejo de Gobierno de la Comunidad de Madrid, señalan en su artículo 1 que "[l]a Universidad Politécnica de Madrid es una Entidad de Derecho Público que goza de plena personalidad jurídica y patrimonio propio para la consecución de sus fines y el desarrollo de sus funciones». Las prerrogativas de la Universidad Politécnica de Madrid se encuentran en el artículo 4 que analiza su régimen jurídico.

${ }^{6}$ La autonomía es un principio básico del sistema educativo español y de toda la acción educativa. La Ley Orgánica 1/1990, de 3 de octubre, de Ordenación General del Sistema Educativo reconoce autonomía pedagógica, autonomía organizativa y autonomía económica a los centros, dentro del marco establecido por las Leyes. Cfr. M. SATRÚStegul, "Los derechos de ámbito educativo", en L. LóPez GueRRA y otros, Derecho Constitucional I, Tirant lo blanch, $6 .^{\circ}$ ed. Valencia, 2003, pág. 398. Cfr. A. FeRNÁNDEZ-MIRANDA y A. SánChez NAVARRO, "Artículo 27. Enseñanza", en O. Alzaga VILLAMIL, Comentarios a la Constitución Española de 1978, cit. págs. 159-272; F. J. DíAz REVORIO, Los derechos fundamentales de ámbito educativo en el ordenamiento estatal y autonómico de Castilla La Mancha, Toledo, 2002.

7 Cfr. más ampliamente cfr. J. M. BAÑo LEÓN, "La distinción entre derecho fundamental y garantía institucional en la Constitución española", REDC núm. 24, 1988, págs. 155-179; F. RUBIo LLORENTE, "La constitución como fuente del Derecho", en La forma del poder. Estudios sobre la Constitución, CEC, Madrid, 1993, págs. 93-95; A. Gallego ANABITARTE, Derechos fundamentales y garantías institucionales, CivitasUAM, Madrid, 1994; L. LóPEZ GUERRA, Introducción al Derecho Constitucional, Tirant lo blanch, Valencia, 1994, págs. 116-117; L. PAREJo Alfonso, Garantía institucional y autonomías locales, IEAL, Madrid, 1981, págs. 11-56.

$8 \mathrm{Cfr}$. J. Leguina VILLA, "La autonomía universitaria en la jurisprudencia del Tribunal Constitucional», cit. págs. 1199-1204. 
démica o como garantía institucional, es de configuración legal9 ${ }^{9}$. El legislador debe respetar el contenido esencial del derecho o los rasgos principales de la garantía institucional, pero tiene libertad para establecer elementos organizativos y funcionales comunes a todas las Universidades, como el sistema para resolver los concursos de provisión de plazas, para establecer normas básicas de creación, supresión o modificación de Departamentos, para fijar módulos objetivos de capacidad de los centros, para la programación general de la enseñanza universitaria, etc. La autonomía en las Universidades Públicas se materializa especialmente a través del procedimiento democrático para elegir a sus órganos de gobierno. Las Universidades Privadas son también autónomas frente a la Administración Pública — dependen de sus consejos de administración-, sin perjuicio de la función de control que ejercen las Comunidades Autónomas. Tienen que respetar el principio de libertad académica manifestada en las libertades de cátedra, de investigación y de estudio, así como la participación adecuada de la comunidad universitaria —art. 6 LOU—. La Ley Orgánica 6/2001, de 21 de diciembre, de Universidades ha regulado, como veremos más adelante, la articulación de las competencias del Estado y de las Comunidades Autónomas sobre las Universidades.

\section{LA PROTECCIÓN DE DATOS PERSONALES EN LA UNIVERSIDADES}

a) Las tecnologías de la información y los tratamientos de datos personales en las Universidades. Las Universidades ante la legislación de protección de datos personales.

La introducción de las tecnologías de la información y la comunicación ha sido y es de gran importancia en las Administraciones Públicas en general y en las Universidades en particular ${ }^{10}$. Los modernos sistemas de información se han convertido en imprescindibles en las Universidades, aportando indudables ventajas a las que ya no es posible ni deseable renunciar. Las tecnologías de la información y las comunicaciones, especialmente Internet, permiten que las Universidades suministren una información actualizada a los alumnos, a los profesores y a la sociedad en general sobre los servicios que prestan. Igualmente faci-

9 Cfr. también SSTC 58/1989, de 23 de febrero, 106/1990, de 6 de junio, y 130/1991, de 6 de junio, sobre autonomía universitaria.

10 Cfr. A. Troncoso Reigada, "Presentación» en Manual de Protección de Datos para las Administraciones Públicas, Civitas-APDCM, Madrid, págs. 5-9. 
litan la relación entre profesores y alumnos, que se puede desarrollar ahora también a través de medios electrónicos, como el correo electrónico o chats, y permite la tramitación de muchos procedimientos administrativos como la matriculación en la Universidad, la calificación de los profesores y su notificación a los alumnos, todo ello a través de Internet. Por tanto, como ocurre con toda la Administración Pública, las Universidades no sólo pueden sino deben recurrir a las nuevas tecnologías para ser más eficaces en el servicio al interés general -art. $103 \mathrm{CE}-{ }^{11}$.

Las Universidades siempre han desarrollado tratamientos de datos personales. Obviamente, las Universidades no registran datos personales de manera caprichosa sino para cumplir una actividad administrativa. Es decir, se recogen datos de personas para cumplir unas funciones que la sociedad demanda de la Administración y que están previstas en la legislación. Estas funciones requieren la recogida y almacenamiento de datos personales. Los principales colectivos afectados por estos tratamientos son alumnos, profesorado y personal de administración y servicios. También se almacenan datos de padres o tutores, de pacientes en el caso de hospitales universitarios o de personas ajenas a la Universidad pero vinculadas a ésta por proyectos de investigación o por su condición de proveedores de servicios.

Progresivamente se han incrementado los tratamientos de datos personales por las Administraciones Públicas y por las empresas privadas. Al principio, las Universidades almacenaban datos personales únicamente mediante papel. Durante las décadas del setenta y ochenta, las Universidades empezaron a utilizar herramientas informáticas para la gestión de sus procesos administrativos ${ }^{12}$. Así, la informática ha fa-

11 Así, hay que destacar a la Universidad Carlos III de Madrid, que recibió el III Premio a la Excelencia y Calidad del Servicio Público de la Comunidad de Madrid por sus mejoras en la simplificación de los procesos, a través del recurso a las nuevas tecnologías. Cfr. Memoria del III Premio a la excelencia y calidad del servicio público, Comunidad de Madrid, 2000, págs. 18-21.

${ }^{12}$ Se han determinado tres grandes etapas en la historia de la informática: la de la macro-informática, la de la micro-informática y la de las redes mundiales y de internet. La primera etapa, que se corresponde con las primeras aportaciones de la llamada cibernética, dio lugar a los primeros computadores, de gran tamaño pero con una capacidad limitada en comparación con los ordenadores actuales. La segunda etapa nace con la aparición del ordenador personal, con una mayor capacidad de los procesadores y una importante reducción de tamaño, y con la revolución del software y la aparición de entornos amigables, que permite la utilización de los sistemas operativos por todas las personas sin necesidad de conocer complejos lenguajes de programación. La última etapa se caracteriza por la interconexión de los ordenadores a través de redes de comunicaciones, especialmente a través de in-

(C) UNED. Revista de Derecho Político 
vorecido que se inicien nuevos tratamientos de datos personales y que se amplía el número de ficheros informatizados. Al mismo tiempo que se incrementaba el recurso a la informática por los poderes públicos y por los particulares, se ha producido un cambio en la percepción social. Ha aumentado la preocupación de los ciudadanos por el uso de su información personal, que ha llevado a que lo que antes se admitía, ahora es ya inadmisible, con lo que se han incrementado el número de denuncias de los ciudadanos, también en el ámbito universitario. Existe la percepción de que los tratamientos abusivos de datos personales menoscaban una parte importante de nuestra vida. Los ciudadanos empiezan a exigir el control sobre sus datos de carácter personal, lo que obliga a las Universidades a adecuar sus tratamientos de datos personales a la legislación.

De esta manera, el derecho fundamental a la protección de los datos personales reconocido en el art. 18.4 CE, desarrollado por el legislador a través de la Ley Orgánica 15/1999, de 13 de diciembre, de Protección de Datos de Carácter Personal _LOPD_ y definido por el Tribunal Constitucional en la Sentencia 292/2000, de 30 de noviembre, cobra gran actualidad $^{13}$. No se trata de limitar la utilización de las tecnologías de la información por parte de las Universidades sino de hacer compatible el desarrollo de la informática con los derechos de los ciudadanos. La legislación de protección de datos personales recoge un conjunto de garantías para los ciudadanos y obliga a todas las Administraciones, entre ellas a las Universidades, a respetar unos principios de protección de datos - calidad, información, consentimiento, datos especialmente protegidos, seguridad informática, deber de se-

ternet. Hoy en día se plantea la creación de una nueva red más rápida y fiable - Internet 2- por parte de las Universidades americanas y el sector privado. Cfr. R. MARTÍNEZ, Una aproximación crítica a la autodeterminación informativa, Civitas, Madrid, 2004, págs. 21-27. Cfr. S. GAUTHRONET y F. NATHAN, Les services en ligne et la protection des donées et de la vie privée, Etude pour la Comission des Communautés Européennes, ARETE, Coopérative Informatique, 1998. No obstante, según E. Fernández, la situación de las tecnologías de la información en las Universidades se encuentra entre cinco y diez años atrás que en las entidades empresariales. Estaría todavía en una etapa de gestión de infraestructuras cuando debería estar en la gestión de servicios y en el gobierno de las tics. Este autor propone en su tesis doctoral un modelo para el gobierno y gestión de las tics sencillo y práctico, adaptado a las Universidades Públicas. E. Fernández VICENTE, UNiTIL: Modelo de Gobierno y Gestión de las TIC para Universidades, Universidad Rey Juan Carlos, Dpto. de Estadística e Investigación Operativa, julio, 2006.

${ }^{13}$ Cfr. A. Troncoso ReIGADA, "La protección de datos personales. Una reflexión crítica de la jurisprudencia constitucional», Cuadernos de Derecho Público 19-20, 2003, págs. 231-334. 
creto-y unos derechos relativos a la protección de datos personales impugnación de valoraciones, acceso, rectificación, cancelación, indemnización-14. Con el cumplimiento de la legislación, las Universidades pueden alcanzar un equilibrio que permita aprovechar la informática en la gestión universitaria sin menoscabar los derechos de las personas.

En esta dirección hay que señalar que el Grupo Parlamentario Socialista en el Senado ha presentado una enmienda al Proyecto de Ley Orgánica por la que se modifica la Ley Orgánica 6/2001, de 21 de diciembre, de Universidades, para añadir una Disposición adicional vigésimo primera titulada "Protección de datos de carácter personal». En ella se afirma que "[l]o establecido en la Ley Orgánica 15/1999, de 13 de diciembre, de Protección de Datos de Carácter Personal, será de aplicación al tratamiento y cesión de datos derivados de lo dispuesto en esta Ley Orgánica. Las universidades deberán adoptar las medidas de índole técnica y organizativa necesarias que garanticen la seguridad de los datos de carácter personal y eviten su alteración, tratamiento o acceso no autorizados ${ }^{15}$. Esta enmienda tiene la virtualidad de recordar —no olvidemos la función pedagógica de las normas- que las Universidades llevan a cabo tratamientos de datos personales y tienen que respetar el derecho fundamental a la protección de datos personales. En todo caso, como veremos más adelante, esta enmienda va encaminada principalmente a cumplir la exigencia de la LOPD de que toda cesión de datos personales - de alumnos y profesores-que se vaya a hacer sin consentimiento del interesado disponga de una adecuada habilitación legal —art. 11-.

Hay que reconocer que no hay mucha sensibilidad hacia la protección de datos en el entorno universitario ${ }^{16}$. Existe un cierto retraso de las Universidades en el cumplimiento de la LOPD. Entre las principales causas se podrían destacar ${ }^{17}$ : la falta de implicación de los órganos di-

${ }^{14}$ Cfr. Guía de protección de datos personales para Universidades, CivitasAPDCM, 2004.

${ }^{15}$ La enmienda se encuentra recogida en el BOCG, Senado, Serie II, 19 de febrero de 2007. El Proyecto de Ley está publicado en el BOCG, Congreso, Serie A, núm. 101-1, 8 de septiembre de 2006.

16 E. FERNÁNDEZ -op. cit.- considera que en el ámbito de las Universidades las normas rígidas y sancionadoras generan un rechazo frontal, por lo que pone el énfasis en el cumplimiento de la legislación a través de una actividad de sensibilización y educación. En este ámbito hay que destacar la aprobación de un Código Tipo en la Universidad de Castila la Mancha.

${ }_{17}$ Cfr. E. FernándeZ, op. cit. - 
rectivos y la carencia de definición de un responsable, lo que conlleva su delegación a los servicios de informática ${ }^{18}$; la necesidad de modificar hábitos arraigados en el contexto universitario - como la forma de publicación de notas-; la descentralización universitaria en órganos con competencias propias - campus, escuelas o facultades, departamentos, áreas, institutos, fundaciones, centros- que hace que exista una fuerte tendencia a la replicación de datos; las dificultades de control sobre tratamientos que desarrollan los profesores y que permanecen al margen de la infraestructura organizativa y tecnológica de la Universidad $^{19}$; y los déficits administrativos de las Universidades ${ }^{20}$.

\section{b) La identificación de los tratamientos de datos personales y la declaración de ficheros por las Universidades}

A la hora de empezar a desarrollar una política universitaria orientada al cumplimiento de la legislación de protección de datos personales y al respeto a este derecho fundamental, un elemento obligado es la declaración de los ficheros y su inscripción en el Registro General de Protección de Datos. Estamos hablando, por tanto, de regularizar los tratamientos de datos personales de las Universidades. Para ello, es necesario, en primer lugar, identificar e inventariar los ficheros de datos personales de una Universidad. Si lo que justifica los tratamientos de datos personales por las Universidades son las funciones que cumplen, la mejor manera de identificar los ficheros es analizar las funciones genéricas de las instituciones universitarias. Es decir, son los procesos de gestión de las Universidades los que justifican y los que permiten analizar sus tratamientos de datos personales.

18 No está claro qué área o departamento debe encargarse de velar por el cumplimiento interno de la legislación de protección de datos, lo que hace que el tema se derive frecuentemente a los servicios de informática, en la creencia de que sólo existen implicaciones técnicas y de seguridad. Además, existe un modelo reactivo: sólo se reacciona ante un problema determinado.

19 Existen ficheros de alumnos de prácticas que recopilan directamente los profesores por cuenta propia; ficheros de investigadores que mantienen los departamentos y grupos de investigación; ficheros de asistentes a cursos, jornadas que no pertenecen a enseñanzas regladas y que no suelen pasar por los órganos de gestión habituales; etc. Todo ello consecuencia de una cierta anarquía intrínseca a la Universidad.

${ }^{20}$ La verdad es que la Universidad no ha sido tradicionalmente la Administración que mejor funciona. La propia autonomía universitaria, si bien ha potenciado la democracia interna al ser elegidos los órganos de gobierno, no ha profesionalizado en exceso los cargos académicos que no tienen porqué saber mucho de gestión pública. 
Es de especial importancia la delimitación de los tratamientos informatizados de las Universidades. En estos ficheros deben implantarse las medidas de seguridad adecuadas al tipo de datos de carácter personal objeto de tratamiento, como consecuencia, como veremos después, del principio de seguridad de los datos - art. 9 LOPD—. Todos los ficheros informatizados deben tener implantadas las medidas de seguridad de nivel básico, ya que son aplicables para todos los ficheros que contengan datos de carácter personal; se deben implantar medidas de nivel medio, para todos los ficheros que traten datos sobre infracciones administrativas, infracciones penales, datos tributarios o de solvencia patrimonial o de crédito, o donde la acumulación de datos de nivel básico pueda configurar un perfil de una persona; de nivel alto las medidas son aplicables a los ficheros que contengan información sobre ideología, religión, creencias, origen racial, raza o vida sexual. Normalmente los datos personales que se recogen en las Universidades son datos identificativos de las personas como el nombre, domicilio, teléfono o dirección de correo electrónico. Pero también las Universidades manejan datos de infracciones administrativas o una información que lleva a determinar perfiles de las personas; por último, los ficheros de las Universidades contienen también datos especialmente protegidos como los datos de ideología, afiliación sindical, salud, que obligan a implantar medidas de seguridad de nivel alto.

Así, en relación con los alumnos, las Universidades mantienen el fichero de pruebas de acceso, donde se almacenan datos personales -incluso de minusvalías - , direcciones e historial académico de alumnos, incluso de alumnos no admitidos, que quedan almacenados en archivos históricos; el fichero de inscripción y matriculación de alumnos, donde se almacenan direcciones y datos bancarios de alumnos, y donde frecuentemente hay empresas colaboradoras - Bancos- que conocen estos datos y que actúan como auténticos encargados del tratamiento. Este fichero puede ser considerado de nivel medio cuando las asignaturas de libre elección puedan llegar a configurar perfiles de las personas y de nivel alto cuando para la matriculación se tiene en cuenta un dato de salud como es la discapacidad. También hay que destacar el fichero de gestión de becas y ayudas, donde se almacenan datos económicos de los padres y donde se puede llegar a incluir circunstancias sociales o datos de salud - discapacidad-, lo que exige un nivel alto de protección. Hay que destacar también el fichero de expediente académico o de calificaciones de alumnos, con datos de su rendimiento escolar por asignaturas, que permite la gestión académica, traslados de expedientes, actas de examen, gestión de títulos, etc; el fichero de estudios de tercer ciclo — postgrado, doctorado-y proyectos 
de fin de carrera, donde se almacenan en muchas ocasiones datos de inscripción y matriculación de alumnos, y donde hay direcciones, datos laborales y bancarios de licenciados, diplomados y alumnos. Hay que mencionar también el fichero de asociaciones de alumnos, que si contiene datos de alumnos asociados deberá disponer de un nivel de seguridad alto ya que alberga datos de ideología; el fichero de bolsa de empleo, para la gestión y búsqueda de empleo, donde se almacenan direcciones y datos laborales de licenciados y diplomados; o el fichero de tarjeta universitaria, que contiene datos identificativos, dirección, teléfono, incluso la imagen y que es necesario para la emisión del carné o la tarjeta universitaria.

En relación con los tratamientos de datos personales de profesores, hay que destacar el fichero de evaluación de la docencia del profesorado, con calificaciones y comentarios de los alumnos sobre los profesores y que permite valorar la calidad de la enseñanza. Por último, en relación con el funcionamiento de la Universidad, hay que mencionar el fichero de nómina o de recursos humanos, con datos económicos, pero también con datos de minusvalías, de cuota sindical, de circunstancias familiares o de número de días de baja por enfermedad común o profesional, por lo que debe tener un nivel de seguridad alto ${ }^{21}$; el fichero de miembros de órganos de gobierno de la Universidad —como el fichero del claustro- que debe tener un nivel alto al recogerse la orientación ideológica de sus miembros; el fichero de biblioteca y servicios, que puede incluir la sanción administrativa por infracciones y que puede servir para elaborar perfiles de las personas por los libros pedidos, por lo que debe tener un nivel medio (este fichero puede incluso calificarse como de nivel alto si de los libros pedidos puede determinarse la ideología, la religión o la orientación sexual de los usuarios); el fichero de tarjeta universitaria, para la identificación y el control

21 No obstante, hay que señalar que el Proyecto de Real Decreto por el que se aprueba el Reglamento de Desarrollo de la LOPD señala en su art.78.4 que podrán adoptar las medidas de seguridad de nivel básico "[I]os ficheros o tratamientos automatizados que contengan datos relativos a la ideología, afiliación sindical, religión o creencias, así como a la salud, cuya finalidad sea únicamente la gestión de obligaciones por el retenedor o la transferencia dineraria a las entidades de las que los afectados sean asociados o miembros" y "[I]os ficheros o tratamientos automatizados que contengan datos relativos a la salud, cuando, con motivo del cumplimiento de deberes públicos, deban tratarse datos que no incluyan ninguna referencia a una enfermedad concreta o al historial clínico del paciente, como el porcentaje de discapacidad o la simple declaración de la condición de discapacidad o invalidez del titular de los datos". 
de accesos, que facilita el uso de instalaciones; el fichero de registro general con datos de entrada y salida de documentos; el fichero del servicio médico, para la asistencia sanitaria y prevención de la salud laboral del personal de la Universidad y que debe tener medidas de seguridad de nivel alto ${ }^{22}$; el fichero con la lista de distribución de correo electrónico, al ser éste un dato de carácter personal; el fichero del control horario, con datos de cumplimiento horario del personal; el fichero de suscriptores de revistas o del servicio de publicaciones de la Universidad; el fichero de mailing o listado comercial para la comunicación de iniciativas y masters ${ }^{23}$; el fichero de pacientes o de prácticas clínicas en el caso de Universidades que tengan Facultades de Medicina y Hospitales Universitarios, y que al recoger datos de salud de pacientes requieren un nivel alto de protección, o el fichero de expedientes de personal, que si incluye las infracciones y las sanciones debe tener un nivel medio.

En lo relativo a la declaración de los ficheros, existe también una gran diferencia entre las Universidades Públicas y las Universidades Privadas. Así, hay que destacar que la declaración de ficheros de las Universidades Públicas tiene que respetar el procedimiento para la creación, modificación y supresión de ficheros públicos establecido en la LOPD. Así, la declaración de los ficheros públicos sólo podrá hacerse a través de una disposición de carácter general que tiene que ser publicada en un diario oficial —art. 20 LOPD—, a diferencia de los ficheros privados que se crean a través de una notificación a la Agencia Española de Protección de Datos. Corresponde ahora precisar qué se entiende por una disposición de carácter general en el ámbito de las Universidades Públicas.

Como hemos señalado antes, el art. 27.6 de la Constitución reconoce la autonomía universitaria. Igualmente, la Ley Orgánica 6/2001, de 21 de

${ }^{22}$ En relación con los reconocimientos médicos que se realicen a cualquier trabajador por parte de la Universidad como consecuencia de la actividad de vigilancia de la salud que el empresario debe hacer en cumplimiento de la Ley 31/1995, de 8 de noviembre, de Prevención de Riesgos Laborales, hay que señalar que la Universidad no puede tener acceso a la información médica resultante del reconocimiento sin el consentimiento del trabajador. El acceso a dicha información de salud se limitará al personal médico y a las autoridades sanitarias que lleven a cabo la vigilancia de la salud. El empresario únicamente puede conocer si el trabajador es o no apto para el trabajo - art. 22-.

${ }^{23}$ A partir de la Ley 34/2002, de 11 de julio, de Servicios de la Sociedad de la Información y de Comercio Electrónico es necesario un consentimiento expreso para estar en ese listado comercial, estando obligados los envíos comerciales a identificarse como tales. 
diciembre, de Universidades (LOU) establece en su art. 2.1 que "las Universidades están dotadas de personalidad jurídica y desarrollan sus funciones en régimen de autonomía y de coordinación entre todas ellas». La autonomía de las Universidades equivale, en este caso, a una suerte de autonormación, de manera que tienen capacidad para aprobar no sólo normas de organización interna sino también normas vinculantes para los miembros de la comunidad universitaria. Por tanto, las disposiciones de carácter general que declaran los ficheros tienen que ser aprobadas por las propias Universidades Públicas y no por su Administración de tutela - por ejemplo, por orden de la Consejería de Educación-. No obstante, la LOU, a pesar de reconocer la autonomía de las Universidades, sólo atribuye a éstas la capacidad de elaboración de sus Estatutos, siendo éstos aprobados por Decreto del Consejo de Gobierno de cada Comunidad Autónoma previo control de legalidad. -art. 6 LOU-.

No es fácil determinar a qué órgano le corresponde aprobar la disposición de carácter general que declara el fichero. Como señala el art. 13 de la LOU, los Estatutos de las Universidades Públicas establecerán como mínimo un conjunto de órganos colegiados y unipersonales. Entre los órganos colegiados estarían el Consejo Social, el Consejo de Gobierno, el Claustro Universitario, la Junta Consultiva, las Juntas de Facultad, de Escuela Técnica o Politécnica Superior y de Escuela Universitaria o de Escuela Universitaria Politécnica, y Consejos de Departamento. Entre los órganos unipersonales se encuentran los siguientes: Rector, Vicerrectores, Secretario General, Gerente, Decanos de Facultades, Directores de Escuelas Técnicas o Politécnicas Superiores, de Escuelas Universitarias o Escuelas Universitarias Politécnicas y Directores de Departamentos y de Institutos Universitarios de Investigación.

En la determinación de la capacidad para elaborar disposiciones de carácter general habrá que estar también a lo que determinen los respectivos Estatutos ${ }^{24}$. Ahora bien, si el responsable del fichero puede ser cualquier órgano de la Universidad, que decide la finalidad, contenido

24 La Comunidad de Madrid aprobó el Decreto 99/2002, de 13 de junio, del Gobierno de la Comunidad de Madrid que regula el procedimiento de elaboración de disposiciones de carácter general de creación, modificación y supresión de ficheros que contienen datos de carácter personal, así como su inscripción en el Registro de Ficheros de Datos Personales de la Comunidad de Madrid. Este Decreto 99/2002 establece que "[I]as Universidades Públicas, en los términos señalados en el art. 2 de la Ley Orgánica 6/2001, de 21 de diciembre, de Universidades, crearan, modificaran y suprimirán sus ficheros mediante disposición de carácter general, de acuerdo con lo establecido por sus respectivos Estatutos». 
y uso del tratamiento de datos de carácter personal —art. 3.d) LOPD, parece apropiado que la disposición de carácter general que declare los ficheros sea aprobada por el Rector de la Universidad, por su Consejo de Gobierno o por el Claustro ${ }^{25}$. Así, tienen el valor de disposición de carácter general los acuerdos del Consejo de Gobierno de una Universidad Pública o las órdenes o resoluciones de su Rector. En cambio, un Acuerdo de un Consejo de Departamento no sería una disposición de carácter general.

Por último, los ficheros de las Universidades Públicas deben ser inscritos en el Registro General de Protección de Datos y en el Registro autonómico correspondiente. Así, las leyes de creación de Agencias Autonómicas de Protección de Datos Personales han establecido que los tratamientos de datos personales de las Administraciones públicas que están dentro de su ámbito competencial tienen que ser inscritos en los Registros autonómicos de datos de carácter personal ${ }^{26}$.

La declaración de ficheros por parte de las Universidades Privadas es claramente distinta al de las Universidades Públicas. Si éstas son Administraciones Públicas y siguen por ello el régimen jurídico de creación de ficheros públicos, los tratamientos de datos personales por parte de las Universidades Privadas tienen la consideración de ficheros privados y no son creados a través de disposición de carácter general sino mediante una notificación al Registro General de Protección de Datos de la Agencia Española - art. 25 LOPD_, un régimen semejante al de las empresas privadas.

${ }^{25}$ Así, la Universidad Autónoma de Madrid ha declarado sus ficheros por Orden del Rector, como por ejemplo, la Orden de 17 de abril de 2002, que crea el fichero que contiene datos de carácter personal del estudio epidemiológico «Envejecer en Leganés". La Universidad Carlos III de Madrid ha declarado sus ficheros por Resolución de la Universidad - por ejemplo, las Resoluciones de 20 de mayo de 2004 y de 26 de noviembre de 1998 por las que se regulan los ficheros de tratamiento automatizado de datos de carácter personal de dicha Universidad.-Con anterioridad la Universidad Carlos III aprobó la Resolución de 20 de julio de 1994. Recientemente la Universidad Complutense aprobó la Resolución Rectoral de 4 de septiembre de 2006, por la que se publica el Acuerdo del Consejo de Gobierno de la Universidad Complutense de Madrid de 10 de marzo de 2006 por el que se aprueba la creación, modificación y supresión de los ficheros de datos de carácter personal de esta Universidad.

${ }^{26}$ Cfr. art. 18 de la Ley $8 / 2001$, de 13 de julio, de Protección de Datos de Carácter Personal en la Comunidad de Madrid; art. 15.2 de la Ley 5/2002, de 19 de abril, de creación de la Agencia Catalana de Protección de Datos; art. 18.1 de la ley 2/2004, de 25 de febrero, de Ficheros de Datos de Caracter Personal de Titularidad Pública y de creación de la Agencia Vasca de Prortección de Datos. 
A la hora de proceder a la declaración del fichero por parte de las Universidades, es necesario establecer quién será su responsable. Como hemos indicado, la LOPD señala que el responsable del fichero es la persona física o jurídica que decide sobre la finalidad, contenido y uso del tratamiento. En las Universidades Públicas, normalmente, el responsable del fichero es el órgano administrativo que tiene la competencia para la cual el fichero es instrumental ${ }^{27}$. Realmente existen dos opciones. Una sería establecer como responsable de los ficheros a órganos centralizados, que podría ser la Secretaría General de la Universidad, la Gerencia o los Vicerrectores. Esta opción presenta la ventaja de que, al tratarse de un órgano central y elevado jerárquicamente, se pueden implantar más fácilmente las medidas de seguridad, el documento de seguridad o desarrollar una política homogénea de formación y concienciación del personal que trata los datos personales que facilite el respeto a los principios y a los derechos de los titulares de los datos. La segunda opción es descentralizar en los distintos órganos de la Universidad la figura del responsable del fichero, responsabilidad que podría recaer, por ejemplo, en un Director de Área. Esta segunda opción tiene la ventaja de que suele ser el órgano inferior quién decide sobre finalidad, contenido y usos de los ficheros. El problema de esta segunda opción estriba en que estas personas suelen estar más implicadas en la gestión administrativa que justifica la creación del fichero pero menos formadas y menos sensibilizadas con la protección de datos personales. Además, es difícil articular una política de protección de datos y de seguridad homogénea y garantista al mismo tiempo si la figura del responsable del fichero está muy descentralizada ya que la adecuación de los tratamientos a la legislación se lleva a efecto más fácilmente a través de órganos horizontales y de jerarquía superior ${ }^{28}$. En todo caso, la determinación del responsable del fichero también de-

27 La Ley 8/2001, de 13 de julio, de Protección de Datos de Carácter Personal en la Comunidad de Madrid señala que el responsable del fichero es el órgano que ostenta la representación legal de las funciones a las que el fichero da apoyo, en el caso de que el fichero se comparta entre varios órganos y responsables.

28 Así, por ejemplo, a la hora de establecer el responsable de un fichero de suscriptores de revistas especializadas, puede atribuirse esta responsabilidad a un órgano centralizado como la Secretaría General o a un órgano descentralizado como la Dirección del Departamento que edite la Revista. En el primer supuesto, el Secretario o la Gerencia de la Universidad sería el responsable de un único fichero de suscriptores de Revistas y podría impulsar los principios, los derechos y la implantación de unas medidas de seguridad comunes. En el segundo supuesto, tendríamos tantos responsables de ficheros como revistas hubiera en la Universidad, lógicamente, todas ellas con su documento de seguridad. 
pende de la existencia de un modelo centralizado o descentralizado de aplicativos informáticos.

c) Los principios y derechos de protección de datos aplicados a las Universidades. Los ficheros de las Universidades públicas como ficheros públicos y su regulación específica. El ejemplo de las encuestas académicas.

En los tratamientos de datos por las Universidades, éstas deben garantizar los principios de protección de datos y los derechos de las personas en este ámbito. Es primordial cumplir el principio de calidad que prohíbe recoger datos excesivos o innecesarios para el fin que se persigue y que obliga a que los datos sean exactos y puestos al día de forma que respondan con veracidad a la situación del afectado - art. 4 LOPD- Igualmente es muy importante, especialmente después del reforzamiento que ha supuesto la STC 292/2000, de 30 de noviembre, garantizar el principio de información a los interesados en el momento de la recogida de los datos sobre la existencia de un fichero, su finalidad, los destinatarios de la información, el carácter obligatorio o facultativo de su respuesta y de las consecuencias de la obtención de los datos y de la negativa a suministrarlos, de la posibilidad de ejercitar los derechos de acceso, rectificación, cancelación y oposición y de la identidad y dirección del responsable del tratamiento - art. 5 LOPD -29 . La normativa de protección de datos exige como regla general el consentimiento del interesado para el tratamiento de sus datos personales. No obstante, las Universidades pueden tratar información de sus alumnos sin su consentimiento ya que los datos se refieran a las partes de un contrato o precontrato de una relación negocial y son necesarios para su mantenimiento y cumplimiento -art. 6.2-30. Las Universidades públicas lo ha-

29 La Agencia de Protección de Datos de la Comunidad de Madrid ha propuesto un texto de leyenda informativa: "Los datos personales recogidos serán incorporados y tratados en el fichero (indicar nombre), cuya finalidad es (describirla), y podrán ser cedidos a (indicar), además de otras cesiones previstas en la Ley. El órgano responsable del fichero es (indicarlo), y la dirección donde el interesado podrá ejercer los derechos de acceso, rectificación, cancelación y oposición ante el mismo es (indicarla), todo lo cual se informa en cumplimiento del artículo 5 de la Ley Orgánica 15/1999, de 13 de diciembre, de Protección de Datos de Carácter Personal.»

30 Las Universidades solo mantienen una relación jurídica con los alumnos pero no con los antiguos alumnos, por lo que cualquier tratamiento de información de antiguos alumnos con finalidad de comunicación comercial requiere el consentimiento del afectado. No obstante, es razonable la solicitud de información dirigida a 
cen, además, para el cumplimiento de funciones administrativas, lo que también excepciona el consentimiento del interesado.

Es también de especial importancia, como hemos señalado antes, el principio de seguridad de los datos - art. 9 LOPD-. Este principio obliga al responsable del fichero $y$, en su caso, al encargado del tratamiento, a adoptar las medidas técnicas y organizativas necesarias que garanticen la seguridad de los datos personales y eviten su alteración, pérdida, tratamiento o acceso no autorizado, teniendo en cuenta el estado de la tecnología, la naturaleza de los datos y los riesgos a los que éstos están expuestos, prohibiendo que se registren datos de carácter personal en ficheros que no reúnan las condiciones que se han establecido en el Real Decreto 994/1999, de 11 de junio, por el que se aprueba el Reglamento de Medidas de Seguridad de los ficheros automatizados que contengan datos de carácter personal ${ }^{31}$. Las medidas de seguridad de los ficheros pueden ser de nivel básico, medio o alto, dependiendo, como hemos señalado, del tipo de datos personales incluidos en el fichero. En todo caso, además de la importancia de la implantación de las medidas de seguridad como garantía de la confidencialidad, es necesario tener en cuenta la importancia de la seguridad informática como garantía de la integridad y de la disponibilidad de la información. Así, por ejemplo, es indispensable que en las Universida-

los antiguos alumnos de la Universidad acerca del grado de inserción laboral. Dentro de la relación académica que una Universidad mantiene con los alumnos y dentro de las funciones propias de ésta se encuentra la evaluación constante de la enseñanza para lo cual son relevantes los datos relativos a inserción laboral.

${ }^{31}$ Buena muestra de que la seguridad informática es un tema importante es que uno de los procedimientos de infracción administrativa que se han iniciado en el ámbito de las Universidades Públicas se ha producido por infracción del art. 9 LOPD. Así, la Resolución de la Agencia Española de Protección de Datos de infracción administrativa contra la Universidad de Castilla La Mancha se produjo por un fallo de seguridad que permitió acceder por internet a información sobre las páginas web a las que accedían el personal de la Universidad. La Resolución de la Agencia Española declaró una infracción grave por poner a disposición del público un fichero con datos de acceso a direcciones de intenet de los trabajadores de la Universidad: "Volcaron en una página web de acceso público la relación de datos personales de aquellos empleados que accedieron a sitios de Internet junto con la identificación de dichas páginas". Esto permite configurar un retrato personal de los miembros de esa Universidad: "La inexistencia de seguridad tras el volcado de ficheros conteniendo datos personales a un sitio de acceso público es manifiesta y se corre el peligro de que se siga el rastro que van dejando quienes acceden a distintas páginas de internet $y$, a partir de las preferencias, aficiones o intereses que de este itinerario quepa deducir, se acabe elaborando un perfil sobre la personalidad de esos usuarios en la Red". 
des haya entornos seguros que eviten no sólo un acceso indebido a las actas y expedientes informatizados de los alumnos sino también su pérdida o su falsificación. Hemos hecho únicamente referencia a los principios de calidad, información, consentimiento y seguridad. Obviamente, las Universidades se encuentran sometidas a otros principios como el deber de secreto y a los derechos de acceso, oposición, rectificación y cancelación ${ }^{32}$.

Los ficheros de las Universidades públicas y privadas tienen un régimen jurídico distinto. Conviene mencionar que los ficheros públicos disponen de un régimen específico previsto en la LOPD y en la Directiva 95/46 CE. Todos los ficheros de las Universidades públicas tienen el carácter de ficheros públicos. No se da aquí la dualidad que se produce en los tratamientos de datos de los Colegios Profesionales, que pueden ser públicos o privados dependiendo de si las funciones que justifican la creación del fichero son funciones administrativas que suponen el ejercicio de potestades públicas o funciones privadas de estos Colegios como asociaciones de particulares. Es decir, las Universidades Públicas, a diferencia de las Corporaciones de Derecho Público, no tienen ficheros públicos y privados sino que sólo tienen ficheros públicos ${ }^{33}$.

Por tanto, le es de aplicación a todos los ficheros de las Universidades públicas la especial regulación de los ficheros públicos configurada a partir de excepciones al régimen general previsto en la LOPD ${ }^{34}$. Así, no es preciso el consentimiento para el tratamiento de los datos personales por parte de las Universidades Públicas al existir una excepción a este principio general de consentimiento para el ejercicio de funciones administrativas - art. 6.2 LOPD— ${ }^{35}$. De esta forma, no es necesario pedir el consentimiento de los profesores para desarrollar una encuesta o evaluación académica de la docencia ya que, como veremos después, ésta es una función administrativa de la Universidad. No es necesario que los alumnos den su consentimiento, por ejemplo, a que se digitalice su fotografía para el carné del estudiante. La fotografía es, sin

32 Nos remitimos para su exposición al Manual de Protección de Datos para las Administraciones Públicas, Cívitas-APDCM, Madrid, 2003, págs. 19-83.

${ }^{33} \mathrm{La}$ diferencia entre los ficheros públicos y los ficheros privados de los Colegios Profesionales se puede ver en la Guía de Protección de Datos para los Colegios Profesionales, Civitas-APDCM, Madrid, 2004.

34 Arts. 6, 11, 20-21 y 46 LOPD.

$35 \mathrm{Si}$ bien los datos personales que recogen las Universidades en el ejercicio de sus competencias administrativas no requieren el consentimiento de los interesados, sí es preciso el consentimiento expreso y escrito para tratar datos especialmente protegidos como la afiliación sindical, religión o creencias —art. 7.2 LOPD—. 
duda, un dato de carácter personal necesario para el desarrollo de muchas actividades universitarias que requieren la identificación de la persona, lo que justifica su tratamiento para la emisión de la tarjeta de identificación de cada alumno ${ }^{36}$.

Existen también límites al ejercicio del derecho de cancelación en relación con tratamientos efectuados por las Universidades Públicas, ya que muchos datos personales en manos de éstas siguen siendo necesarios y pertinentes para el interés público, manteniéndose la finalidad para la que han sido recabados —art. 4.5 LOPD— ${ }^{37}$. Así, por ejemplo, no se pueden cancelar los datos personales de los expedientes académicos. Además, hay un régimen sancionador de los ficheros públicos distinto al de los ficheros privados ${ }^{38}$, no existiendo sanciones económicas impuestas por la autoridad de control, sino que en el supuesto de que se desee un resarcimiento económico, es necesario ejercitar el derecho a la indemnización del art. 19 LOPD ante la jurisdicción contencioso-administrativa. Así, las infracciones de protección de datos cometidas por un responsable de un fichero de una Universidad Pública pueden tener como consecuencia una resolución de la autoridad de control que declara la infracción administrativa, la comunicación de la resolución al defensor del pueblo y al superior jerárquico de la persona que ha cometido la infracción y la propuesta de apertura del procedimiento disciplinario - art. 46 LOPD-.

No es nuestro propósito analizar las peculiaridades de la vigencia de los principios y de los derechos de protección de datos en las Universidades privadas. Las Universidades privadas, al no tener el carácter de Administración Pública, no se benefician del régimen jurídico de los ficheros públicos, especialmente en lo relativo al régimen sancionador. No obstante sí está presente en estas Universidades privadas la excepción al consentimiento del interesado cuando el tratamiento de da-

36 En todo caso, la digitalización de la fotografía, es decir, su traslado de un tratamiento manual a un tratamiento informático afecta especialmente a la aplicación de las medidas de seguridad previstas en el Real Decreto 994/1999, de 11 de junio, que aprueba el Reglamento de Medidas de Seguridad de los ficheros automatizados que contengan datos de carácter personal.

37 Le sería de aplicación a muchos ficheros de las Universidades la previsión del tercer párrafo del art. 4.5 LOPD donde se indica que "[r]eglamentariamente se determinará el procedimiento por el que, por excepción, atendidos los valores históricos, estadísticos o científicos de acuerdo con la legislación específica, se decida el mantenimiento íntegro de los datos".

38 Cfr. más ampliamente el Manual de Protección de Datos para las Administraciones Públicas, cit. págs. 95-99. 
tos se refiera a las partes de un contrato o precontrato de una relación negocial o laboral -art. 6.2 LOPD—. Así, no será necesario recabar el consentimiento de profesores y alumnos en ficheros de personal o de expedientes académicos. Será posible la comunicación de datos de estas Universidades a la Administración Educativa sin consentimiento del interesado ya que frecuentemente existe una habilitación legal -art. 11.2.a) LOPD-. Lo mismo puede decirse en relación con los límites al derecho de cancelación de los datos personales.

Un ejemplo de tratamiento de datos personales que se produce en el ámbito universitario es el derivado de las encuestas académicas de los profesores, donde constan las calificaciones y comentarios de los alumnos y que permite evaluar la calidad de la enseñanza. Para poder desarrollar estas encuestas, en primer lugar, hay que proceder a declarar el fichero de evaluación de la docencia del profesorado, a través de la aprobación de una disposición de carácter general que debe ser publicada y a la inscripción en el Registro. En aplicación del principio de calidad, sólo se pueden incluir en el cuestionario dirigido a los alumnos preguntas orientadas a conocer la calidad de la docencia ya que cualquier otra cuestión supondría un tratamiento de datos excesivo y contravendría este principio. Es importante garantizar la información a los profesores sobre el tratamiento de sus datos personales -art. 5 LOPD-. No hay que olvidar que el principio de información no puede cumplirse en el momento de la recogida de datos ya que se toman de los alumnos - a los que no se les informa porque son anónimas-. Por tanto, la información debe realizarse en otro momento, por ejemplo, en la comunicación dirigida a cada profesor de los resultados de las encuestas.

No es necesario el consentimiento del profesor para el tratamiento de sus datos ya que éste se produce en relación a las partes de una relación laboral o administrativa y los datos personales son necesarios para el mantenimiento y cumplimiento de ésta. Así, la evaluación de la docencia forma parte de la medición del desempeño y de los programas de calidad de una Universidad pública y privada. Además, en el caso de las Universidades públicas existe otra excepción del consentimiento ya que el tratamiento se produce para el desarrollo de funciones administrativas -art. 6.2 LOPD—. Hay también una habilitación legal y normativa que exceptúa del consentimiento ya que las encuestas de evaluación del profesorado se encuentran amparadas en la LOU y en los Estatutos de la Universidad como una función propia de éstas. Es imprescindible que los resultados de las encuestas se mantengan en entornos seguros, de manera que quede garantizada la confidencialidad, esto es, que el acceso a las mismas sólo sea realizado por personal au- 
torizado y no por terceras personas. Si bien los resultados de las encuestas son datos personales de nivel básico, éstas contienen una información comprometedora en un ámbito como el universitario en el que la autoridad y el prestigio científico y docente tienen una especial relevancia. Por tanto, es muy importante implantar las adecuadas medidas de seguridad, tanto informáticas como organizativas o funcionales.

Uno de los aspectos más polémicos de estas encuestas es quién va a tener acceso a los resultados de las mismas. La definición de los usos y del nivel de acceso debe estar presente en la declaración del fichero y en el documento de seguridad. Es el principio de calidad el relevante a la hora de determinar que órganos de la Universidad pueden acceder a estos resultados ya que este acceso no debe entenderse como cesión al producirse dentro del ámbito del mismo responsable del fichero. En la Administración Pública, el principio de calidad está muy vinculado al principio de competencia, de modo que puede acceder a una información quién tenga competencia para ello, es decir, los órganos encargados de la evaluación del profesorado y de velar por el control de calidad de las enseñanzas impartidas en la Universidad. Por tanto, hay que estar a las competencias establecidas en los Estatutos de cada Universidad. Podrán acceder a los resultados los Directores de Departamento o las comisiones de docencia, pero no todos los Vicerrectorados, Decanos de Facultad o Directores de Escuela. Es decir, no puede haber un acceso indiscriminado a los resultados de las encuestas por parte de personas que, a pesar de tener atribuidas funciones de coordinación de las enseñanzas o de programación docente, no tengan la función específica de velar por la calidad de la docencia.

Hemos señalado que si la comunicación de datos se produce a órganos intrauniversitarios no estaríamos hablando de cesión sino de acceso dentro del principio de calidad. No obstante, un caso específico sería el del Defensor Universitario que, si bien forma parte de la Universidad, al disponer de una autonomía organizativa y funcional, no se encuentra bajo las instrucciones del responsable del fichero ${ }^{39}$, por lo que este acceso también pudiera ser considerado una comunicación de datos. No obstante, nos encontraríamos aquí con una habilitación

39 La Disposición Adicional Decimocuarta de la Ley Orgánica 6/2001, de 21 de diciembre, de Universidades establece que el Defensor Universitario no estará sometido a mandato imperativo de ninguna instancia universitaria y su ejercicio vendrá regido por los principios de independencia y autonomía. Corresponde a los Estatutos de las Universidades establecer el procedimiento para su elección o designación, duración de su mandato y dedicación, así como su régimen de funcionamiento. 
legal específica para la cesión que se encontraría en la Disposición Adicional Decimocuarta de la LOU donde se establece que el Defensor Universitario tiene unas funciones dirigidas hacia la mejora de la calidad universitaria y para velar por los derechos de las personas en ese ámbito $^{40}$. Estas funciones justifican el acceso a los resultados de las encuestas para desarrollar una actividad de supervisión de la labor docente. Además, su función de garantía de los derechos y deberes de los miembros de la comunidad universitaria implica una actividad de investigación y una obligación de todos los órganos de remisión de información.

d) La comunicación de datos desde las Universidades a la Administración Pública -a la Policía-y a las empresas privadas. La comunicación de datos a las Universidades con la finalidad de investigación

La normativa de protección de datos exige el consentimiento del interesado para la comunicación de datos a terceras personas. No obstante, existe también un conjunto de excepciones en el ámbito de las Administraciones Públicas. Por ello, las Universidades públicas y las Universidades privadas tienen un régimen diferenciado en relación con las cesiones de datos. Esto es debido a que las Universidades públicas, como ya hemos comentado, tienen el carácter de Administración. No es lo mismo que la comunicación de datos tenga como cedente o como destinataria a una Administración Pública - una Universidad pública - que a un sujeto privado - una Universidad privada-.

Así, es posible la comunicación de datos entre Administraciones Públicas sin consentimiento del interesado para el ejercicio de competencias homogéneas o que versen sobre las mismas materias -art. 21.1 LOPD-. Este precepto exige, en primer lugar, que la comunicación se produzca entre Administraciones Públicas. Así, por ejemplo, puede haber comunicación de datos entre una Universidad pública, la Consejería de Educación de la Comunidad Autónoma respectiva, el Mi-

40 Las Disposición Adicional Decimocuarta de la Ley Orgánica 6/2001, de 21 de diciembre, de Universidades, establece que para velar por el respeto a los derechos y las libertades de los profesores, estudiantes y personal de administración y servicios, ante las actuaciones de los diferentes órganos y servicios universitarios, las Universidades establecerán en su estructura organizativa la figura del Defensor Universitario. Sus actuaciones estarán dirigidas hacia la mejora de la calidad universitaria en todos sus ámbitos. 
nisterio de Educación o la Secretaría de Estado de Universidades ${ }^{41}$. En segundo lugar es necesario que la comunicación se produzca para las mismas materias o las mismas competencias. Es legítima la cesión de datos relativos a la concesión o denegación de becas desde la Universidad pública a la Administración educativa o la cesión de datos entre Universidades públicas. El art. 21.1 LOPD establece que "los datos de carácter personal recogidos o elaborados por las Administraciones Públicas para el desempeño de sus atribuciones no serán comunicados a otras Administraciones Públicas para el ejercicio de competencias diferentes o de competencias que versen sobre materias distintas". No sería posible la comunicación de datos de estudiantes desde una Universidad pública a los servicios administrativos de empleo para un estudio de situación laboral. Al no tratarse de materias comunes, esto requeriría una habilitación legal o el consentimiento del interesado. Para hacer efectivo esto último, la Universidad debe dirigirse a los alumnos, indicando con claridad y precisión la cesión que va a ser realizada, así como la finalidad de la misma, y pidiendo el consentimiento, que podrá ser tácito.

También es posible la cesión de datos entre Administraciones Públicas sin consentimiento del interesado cuando una Administración recabe los datos con destino a otra. Así, una Universidad pública puede enviar a la Administración aquellas solicitudes que ha recogido del interesado para su envío a la Administración. Además, es legítima la cesión de datos entre Administraciones públicas sin consentimiento del interesado cuando tenga por objeto el tratamiento posterior de los datos con fines históricos, estadísticos o científicos" -arts. 11.2.e) y 21.1 LOPD-. Para que sea posible la cesión con una finalidad estadística, la comunicación tiene que ser dirigida a un servicio de estadística y el estudio debe estar previsto en los planes estadísticos correspondientes. Muchas veces no es necesaria la cesión de información personal ya que bastaría la información disociada ${ }^{42}$. Las cesiones de datos a otros paí-

41 Así, sería legítima la cesión de datos personales de profesores desde la Universidad pública a las Agencias Nacionales o Autonómicas de Evaluación de la Calidad. En cambio, las cesiones de datos personales desde las Universidades públicas a las Fundaciones Universidad-Empresa requieren como regla general el consentimiento del interesado al ser privada - y no pública - la naturaleza de estas entidades y no existir previsión legal.

42 Muchos estudios sobre inserción laboral de los titulados universitarios que desea hacer una Administración Autonómica no requieren la identificación de las personas a las que se refieren y, por tanto, no precisan la cesión de datos personales desde las Universidades. 
ses, aunque se realicen a instituciones universitarias, deben respetar la normativa de transferencia internacional de datos ${ }^{43}$.

Las Universidades privadas no se encuentran con el mismo régimen de cesiones de datos a las Administraciones Públicas al no tratarse de una cesión entre Administraciones Públicas. Para que la comunicación de datos desde una Universidad privada a una Administración Pública sea posible sin necesidad de obtener el consentimiento del interesado es necesario que exista una habilitación legal o que se realice dentro de la función estadística en el Plan Nacional o Autonómico correspondiente ${ }^{44}$. En todo caso, no hay que olvidar la habilitación del art. 11.2 c) LOPD que establece la legitimidad de la cesión de datos sin consentimiento del interesado "cuando el tratamiento responda a la libre y legítima aceptación de una relación jurídica cuyo desarrollo, cumplimiento y control implique necesariamente la conexión de dicho tratamiento con ficheros de terceros". Esta previsión daría cobertura a muchas de las comunicaciones de datos que tengan que hacer las Universidades privadas a la Administración educativa cuando no exista una previsión legal específica.

Tanto las Universidades públicas como las privadas tienen que ceder datos sin consentimiento del interesado cuando exista una previsión legal. Esta habilitación permite, por ejemplo, la comunicación de algunos datos de los trabajadores de la Universidad al comité de empresa $^{45}$. También se debe comunicar datos de estudiantes, profesores y

43 Las cesiones de datos de alumnos entre Universidades de distintos países, muy de actualidad a partir del programa Erasmus y de los proyectos de investigación internacionales, se rige por la normativa de transferencia internacional de datos —arts. 33 y 34 LOPD_ y por la Instrucción 1/2000, de 1 de diciembre, de la Agencia de Protección de Datos, relativa a las normas por las que se rigen los Movimientos Internacionales de Datos. Esta cesión es más sencilla dentro del ámbito de la Unión Europea o a un Estado respecto del cual la Comisión de las Comunidades Europeas, en el ejercicio de sus competencias, haya declarado que garantiza un nivel de protección adecuado", sin perjuicio de las obligaciones de notificación de dicha transferencia al Registro Nacional de Protección de Datos.

44 Este sería el marco jurídico para la comunicación de datos de estudiantes desde una Universidad privada a una Administración Autonómica, con la finalidad de conocer, por ejemplo, la tasa de paro por titulación o el tiempo medio en encontrar empleo.

45 En este caso, la Universidad no se encuentra en un supuesto especial sino que se rige por el art. 64.1 del Estatuto de los Trabajadores que prevé esta cesión de datos. Lógicamente, el Comité de Empresa tiene una competencia reglada o taxativa, $\mathrm{y}$, por tanto, no está habilitado para solicitar o recibir información diferente a la señalada en la ley. Por ejemplo, el comité de empresa sí debe tener acceso a la información relativa a la copia básica de los contratos. En todo caso, los miembros del co- 
PAS a las Fuerzas y Cuerpos de Seguridad del Estado cuando éstas los requieran para la prevención de un peligro real para la seguridad pública o para la persecución de delitos - art. 22 LOPD—. Igualmente, las Universidades públicas y privadas deben ceder a la policía datos de estudiantes extranjeros no comunitarios matriculados, a los efectos de obtención y regularización de los permisos de residencia por estudios, en virtud de la Disposición adicional quinta de la Ley Orgánica 4/2000, de 11 de enero, reguladora de los derechos y libertades de los extranjeros en España y su integración social, a partir de la reforma establecida por el art. 1.40 de la Ley Orgánica 14/2003, de 20 de noviembre, relativa al acceso a la información y colaboración entre Administraciones públicas ${ }^{46}$.

Hay que analizar la posibilidad de que las Universidades públicas y privadas sean destinatarias -en este caso, no cedentes- de datos de carácter personal. El ejemplo más claro son las cesiones de datos desde las Administraciones Públicas a las Universidades con la finalidad de investigación. Ya hemos señalado que es legítima la cesión de datos entre Administraciones Públicas sin consentimiento del interesado cuando tenga por objeto el tratamiento posterior de los datos con fines históricos, estadísticos o científicos" - arts. 11.2.e) y 21.1 LOPD—, aunque esta información debe remitirse de una manera preferentemente disociada, como exigencia del principio de calidad y proporcionalidad. Por tanto, las Universidades públicas están habilitadas por la LOPD para obtener datos de las Administraciones Públicas con la finalidad de investigación. Como ya hemos señalado, la Ley Orgánica 6/2001, de 21 de diciembre, de Universidades establece que la investigación científica es

mité de empresa se encuentran obligados por el deber de secreto. Así, además del art. 10 LOPD, hay que recordar también que el art. 65.2 del Estatuto de los Trabajadores señala que los miembros del Comité de Empresa tienen un deber de sigilo.

46 "1. En el cumplimiento de los fines que tienen encomendadas, y con pleno respeto a la legalidad vigente, las Administraciones públicas, dentro de su ámbito competencial, colaborarán en la cesión de datos relativos a las personas que sean consideradas interesados en los procedimientos regulados en esta Ley Orgánica y sus normas de desarrollo. 2. Para la exclusiva finalidad de cumplimentar las actuaciones que los órganos de la Administración General del Estado competentes en los procedimientos regulados en esta Ley Orgánica y sus normas de desarrollo tienen encomendadas, la Agencia Estatal de Administración Tributaria, la Tesorería General de la Seguridad Social y el Instituto Nacional de Estadística, este último en lo relativo al Padrón Municipal de Habitantes, facilitarán a aquellos el acceso directo a los ficheros en los que obren datos que hayan de constar en dichos expedientes, y sin que sea preciso el consentimiento de los interesados, de acuerdo con la legislación sobre protección de datos." 
uno de los fines propios de la Universidad. Esta investigación puede ser realizada tanto de manera institucional - a través grupos de investigación, Departamentos e Institutos Universitarios de Investigacióncomo por los profesores de manera individual —art. 40-. La investigación es un derecho y un deber del personal docente. Sin embargo, sólo la cesión de datos desde la Administración Pública a Departamentos, Institutos Universitarios y Grupos de Investigación tiene el carácter de comunicación entre Administraciones Públicas y puede hacerse sin consentimiento del interesado. Esto no ocurre cuando un profesor o grupo de profesores desarrollen una actividad de investigación que no se enmarque en ningún proyecto institucional ni en un Plan de Investigación. El derecho no puede tratar de manera semejante la actividad investigadora de la que es responsable la propia Universidad Pública - serían ficheros públicos - de la actividad de investigación desarrollada de manera individual por profesores, que debe producirse sin menoscabo de la libertad individual, pero que tiene el carácter de fichero privado.

Este mismo criterio puede ser utilizado para el acceso a datos personales de los estudiantes - nombre y apellidos, titulación-con finalidad de investigación desde la propia Universidad. Es legítimo este acceso sin consentimiento del interesado cuando el estudio lo elabore un Departamento, Instituto o grupo de investigación de la propia Universidad y tenga esa finalidad. En este caso no estaríamos hablando de una cesión de datos ya que se trata de una misma Universidad. Estaríamos en el marco del cumplimiento del principio de calidad. El art. 4.2 LOPD señala que los datos de carácter personal objeto de tratamiento no podrán usarse "para finalidades incompatibles con aquellas para las que los datos hubieran sido recogidos. No se considerará incompatible el tratamiento posterior de éstos con fines históricos, estadísticos o científicos". Si bien un tratamiento de datos para la investigación podría ser diferente de la finalidad de gestión académica para la cual se recogieron los datos, no tendría sentido que la investigación sea una finalidad legítima para la cesión entre distintas Administraciones Públicas y no lo sea para justificar el acceso dentro del ámbito del mismo responsable del fichero. En todo caso, los estudios científicos y de investigación deben tratar preferentemente información disociada.

Analizada ya la comunicación de datos desde las Universidades públicas y privadas a las Administraciones Públicas, nos corresponde estudiar ahora la comunicación de datos que tenga como destinatarios a las empresas privadas. Esta comunicación sólo es posible si existe un consentimiento del interesado, siempre que éste se encuentre informado y conozca la identidad de la empresa destinataria de la informa- 
ción y la finalidad a la que se destinarán los datos. En caso contrario, existiría un vicio de consentimiento - art. 11.3 LOPD-. Así, por ejemplo, la Universidad no puede comunicar a empresas privadas información de los títulos obtenidos por estudiantes de la Universidad rango de los títulos, fecha, domicilio de los estudiantes- si no es con el consentimiento informado de éstos ${ }^{47}$. En este ámbito hay que mencionar la infracción muy grave declarada a la Universidad de Zaragoza por proporcionar a entidades privadas, a cambio de una compensación económica, datos personales de estudiantes matriculados y de titulados en los diferentes estudios académicos, sin el consentimiento informado de los interesados ${ }^{48}$.

e) La aplicación de la normativa de protección de datos personales a los ficheros en soporte papel de las Universidades.

Las Universidades no sólo tienen almacenada información personal en soportes informatizados sino también en papel. Así, los expedientes académicos tradicionalmente se confeccionaban en papel. Inicialmente la normativa de protección de datos no se había extendido a los ficheros manual-estructurados o ficheros en papel sino sólo a los ficheros informáticos. La persona era protegida únicamente frente a los almacenamientos de sus datos personales en soporte informático pero no en papel. Esto es debido a que la percepción de la existencia de una amenaza al derecho a la privacidad personal viene de la mano de la extensión de la informática y de los tratamientos automatizados de datos personales y no tanto a través de los tratamientos manuales. De hecho, cuando se habla de ficheros de datos personales, se piensa inmediatamente en tratamientos de datos informatizados. A pesar de que un acceso indebido a un fichero en papel puede llegar a ser escandaloso - pensemos en una historia clínica abandonada en la calle-, las tecnologías de la información pueden provocar mayores vulneraciones de los derechos, ya que la informática permite una gran capacidad para recoger datos personales, grabarlos y ponerlos en comunicación, facilitando perfiles de las personas. Por ello, el Convenio 108 del Consejo de Europa, de 28 de enero de 1981, se aprobó para la protección de las personas en lo que respecta al tratamiento automatizado de los datos personales.

47 Si bien existe un registro nacional de títulos universitarios, éstos no son fuentes accesibles al público. El acceso a estos registros requiere la condición de interesado. Cfr. Real Decreto 1496/1997, de 6 de noviembre

48 Cfr. más ampliamente infra apdo. 4. c). 
En España, se tardó aún varios años en aprobar la primera Ley, que estuvo destinada también únicamente a los tratamientos automatizados de datos personales. Esta fue, como ya se sabe, la Ley Orgánica 5/1992, de 29 de octubre, de regulación del tratamiento automatizado de los datos de carácter personal. Como la realidad no cambia inmediatamente porque cambien las normas jurídicas, el Reglamento de Medidas de Seguridad de los Ficheros Automatizados se aprobó por el Real Decreto 994/1999, de 11 de junio, a pesar de que el primer borrador era de 1994. Además, la entrada en vigor de las medidas de seguridad básicas, medias y altas fue sucesivamente prorrogada ${ }^{49}$.

Sin embargo, la Ley Orgánica 15/1999, de 13 de noviembre, de Protección de Datos de Carácter Personal, a diferencia de la Ley Orgánica 5/1992, de 29 de octubre, de Regulación del Tratamiento Automatizado de los Datos de Carácter Personal, no se extiende únicamente a la regulación de los ficheros informatizados sino también a los tratamientos de datos personales no automatizados, es decir, en soporte papel. Son los Ilamados ficheros manual-estructurados. El art. 2 LOPD establece como ámbito de aplicación «los datos de carácter personal registrados en soporte físico, que los haga susceptibles de tratamiento, y toda modalidad de uso posterior de estos datos por los sectores público y privado". Además, el art. 3.c) LOPD define como tratamiento de datos las «operaciones y procedimientos técnicos de carácter automatizado $o$ no, que permitan la recogida, grabación, conservación, elaboración, modificación, bloqueo y cancelación, así como las cesiones de datos que resulten de comunicaciones, consultas, interconexiones y transferencias $1{ }^{50}$. Por tanto, todos los tratamientos de datos personales reali-

49 El plazo para las medidas de nivel básico fue ampliado por el Real Decreto 195/2000, de 11 de febrero, desde el 26 de diciembre de 1999 al 26 de marzo de 2000. Las medidas de seguridad de nivel alto fueron también prorrogadas del 26 de junio de 2001 al 26 de junio de 2002, por la Resolución de la Subsecretaría del Ministerio de Justicia de 22 de junio de 2001 -BOE de 25 de junio de 2001-.

${ }^{50} \mathrm{El}$ art. 2.b) de la Directiva define como tratamiento de datos personales "cualquier operación o conjunto de operaciones, efectuadas o no mediante procedimientos automatizados». La Directiva señala que la protección de las personas debe aplicarse tanto al tratamiento automático de datos como al manual, ya que el alcance de la protección no debe depender de las técnicas utilizadas. Así, se indica que los tratamientos amparados por la Directiva son tanto los automatizados como aquellos en los que los datos están contenidos en un archivo estructurado. Ahora bien, la Directiva sólo abarca a los ficheros estructurados y no a las carpetas que no estén estructuradas. Para que pueda hablarse de un fichero manual, éste debe estructurarse conforme a criterios específicos relativos a las personas que faciliten el acceso de forma sencilla a los datos, sin bien corresponde a los Estados la definición de los crite-

(C) UNED. Revista de Derecho Político 
zados en las Universidades, tanto aquellos realizados en soporte electrónico como en papel entrarían dentro del ámbito de aplicación de la Ley Orgánica 15/1999, de 13 de diciembre, de Protección de Datos de Carácter Personal.

La modificación de la LORTAD y la aprobación de la LOPD es una exigencia de la Directiva 95/46/CE del Parlamento y del Consejo, relativa a la protección de las personas físicas con respecto al tratamiento de los datos personales y a la libre circulación de esos datos, que extendía su ámbito de aplicación a los ficheros no automatizados. El art. 2.b) de la Directiva define como tratamiento de datos personales «cualquier operación o conjunto de operaciones, efectuadas o no mediante procedimientos automatizados». La Directiva señala que la protección de las personas debe aplicarse tanto al tratamiento automático de datos como al manual, ya que el alcance de la protección no debe depender de las técnicas utilizadas. Así, se indica que los tratamientos afectados por la Directiva son tanto los automatizados como aquéllos en los que los datos están contenidos en un archivo estructurado. Ahora bien, la Directiva sólo abarca a los ficheros estructurados y no a las carpetas que no estén estructuradas. Para que pueda hablarse de un fichero manual, éste debe estructurarse conforme a criterios específicos relativos a las personas que faciliten el acceso fácil a los datos, sin bien corresponde a los Estados la definición de los criterios que permitan determinar los elementos de un conjunto estructurado de datos de carácter personal. Las carpetas y conjunto de carpetas que no estén estructuradas conforme a estos criterios no estarán comprendidas en ningún caso en el ámbito de aplicación de la Directiva ${ }^{51}$.

Ahora bien, si el legislador ha regulado los ficheros informatizados, tratando de actuar con cautela y previendo los necesarios periodos transitorios, se comprende también la prudencia de éste a la hora de establecer la regulación efectiva del ordenamiento jurídico de protección de datos personales para los ficheros manual-estructurados en nuestro país. Así, la Disposición Adicional Primera de la LOPD relativa a

rios que permitan determinar los elementos de un conjunto estructurado de datos de carácter personal. Las carpetas y conjunto de carpetas que no estén estructuradas conforme a estos criterios no estarán comprendidas en ningún caso en el ámbito de aplicación de la Directiva. Considerandos 15 y 27 de la Directiva 95/46/CE del Parlamento y del Consejo relativa a la protección de las personas físicas con respecto al tratamiento de los datos personales y a la libre circulación de esos datos.

51 Considerandos 15 y 27 de la Directiva 95/46/CE del Parlamento y del Consejo relativa a la protección de las personas físicas con respecto al tratamiento de los datos personales y a la libre circulación de esos datos. 
los ficheros preexistentes señala que «[e]n el supuesto de ficheros y tratamientos no automatizados, su adecuación a la presente Ley Orgánica, y la obligación prevista en el párrafo anterior deberán cumplimentarse en el plazo de doce años a contar desde el 24 de octubre de 2005, sin perjuicio del ejercicio de los derechos de acceso, rectificación y cancelación por parte de los afectados". Por tanto, la vigencia de la legislación de protección de datos sobre los ficheros manuales es más confusa y exige una interpretación compleja.

Así, en relación con los ficheros manuales posteriores a la $L O P D$, se puede afirmar que les es de aplicación esta legislación en su totalidad, tanto en lo relativo a los principios de protección de datos - calidad, información, consentimiento, datos especialmente protegidos, deber de secreto- como a los derechos - acceso, rectificación, cancelación, oposición e indemnización-. Más difícil parece afirmar la vigencia de la normativa de seguridad de los datos, que se refiere a las "medidas de índole técnica y organizativas necesarias que garanticen la seguridad de los datos de carácter personal y eviten su alteración, pérdida, tratamiento o acceso no autorizado, habida cuenta del estado de la tecnología, la naturaleza de los datos almacenados y los riesgos a que están expuestos, ya provengan de la acción humana o del medio físico o natural» - art. 9.1 LOPD - Este precepto hace referencia a medidas organizativas pero también a las de tipo técnico, mencionando el estado de la tecnología, por lo que parece más orientado este principio a los ficheros informatizados, a los que le son de aplicación tanto medidas organizativas o funcionales como medidas técnicas. Esta misma conclusión se puede extraer de la lectura del art. 9.2 LOPD en el que se prohíbe que se registren datos de carácter personal «en ficheros que no reúnan la condiciones que se determinen por vía reglamentaria con respecto a su integridad y seguridad y a las de los centros de tratamiento, locales, equipos, sistemas y programas». Igualmente el art. 9.3 LOPD señala que reglamentariamente se establecerán los requisitos y condiciones "que deban reunir los ficheros y las personas que intervengan en el tratamiento de los datos a que se refiere el art. 7 de esta Ley".

Pues bien, este desarrollo reglamentario se ha efectuado, como ya hemos señalado, a través del Real Decreto 994/1999, de 11 de junio, por el que se aprueba el Reglamento de Medidas de Seguridad de los Ficheros Automatizados que contengan Datos de Carácter Personal. Si bien este Reglamento contiene tanto medidas organizativas y funcionales como medidas técnicas ${ }^{52}$, difícilmente se les pueden exigir

${ }^{52}$ Arts. 8-26 del Real Decreto 994/1999, de 11 de junio. 
jurídicamente a los ficheros manuales la incorporación de unas medidas contenidas en un Reglamento de Medidas de Seguridad para Ficheros Automatizados, y mucho menos que el incumplimiento de estas medidas pueda ser considerado una infracción grave -art. 44.3.h) LOPD-. Una resolución de infracción en este caso podría suponer una vulneración del principio de legalidad en el procedimiento administrativo sancionador que exige que nadie sea sancionado por acciones $u$ omisiones que en el momento de producirse no constituyan infracción administrativa, según la legislación vigente en aquel momento -art. 25.1 CE- Una cosa es que la vigencia de unas medidas de seguridad organizativas previstas en el Reglamento de Medidas de Seguridad pueda recomendarse también en el ámbito de los ficheros manuales, y otra que se pueda exigir jurídicamente y que pueda sustanciar esta inobservancia una resolución de infracción. No olvidemos que están presentes en el procedimiento administrativo sancionador muchos de los principios del derecho penal, entre ellos, el principio de tipicidad -nulla crimen sine legge-. Además de que la analogía está prohibida en el procedimiento administrativo sancionador, la aplicación de un Reglamento de Medidas de Seguridad, que se proclama expresamente para ficheros automatizados, a los ficheros manuales representa un supuesto claro de interpretación extensiva del tipo in malam partem, lo que es incompatible con el principio de legalidad administrativa proclamado en el art. 25.1 CE. La mejor manera para exigir la vigencia de una normativa de seguridad para los ficheros manuales posteriores a la LOPD es, sencillamente, aprobar por Real Decreto un Reglamento de Medidas de Seguridad para los ficheros manual-estructurados ${ }^{53}$. En la actualidad se está elaborando un borrador de Reglamento de desarrollo de la LOPD que tiene entre sus principales novedades el establecimiento de medidas de seguridad para los ficheros manuales.

Ha existido siempre una cierta incertidumbre acerca de la obligación de declarar los ficheros públicos en soporte papel a través de una disposición de carácter general, publicada en el Diario Oficial —art. 20 LOPD - y la de inscribirlos en el Registro General de Protección de Datos, así como sobre la obligación de notificar previamente los ficheros privados manuales a la Agencia Española de Protección de Datos

53 No obstante, a partir de marzo de 2003 la Agencia Española considera que sí es de aplicación el Reglamento de Medidas de Seguridad de los ficheros automatizados a los ficheros manuales. Así, por ejemplo, el Registro General no procede a la inscripción de ficheros manuales que no declaren las medidas de seguridad aplicables —básica, media o alta-. 
—art. 26 LOPD—. La Administración de la Comunidad de Madrid ha optado por declarar sus tratamientos de datos personales en soporte papel mediante disposiciones de carácter general publicadas en el Boletín Oficial de la Comunidad de Madrid, e inscribir estos ficheros manuales en el Registro de Ficheros de Datos Personales de la APDCM. Sin embargo, no existía hasta hace poco tiempo ningún fichero manualestructurado ni público ni privado inscrito en el Registro General de Protección de Datos ${ }^{54}$. Difícilmente puede afirmarse como claramente obligatorio algo que hasta ahora sólo cumple básicamente la Administración de la Comunidad de Madrid. No obstante, nosotros consideramos preceptiva la declaración de los ficheros de datos personales en soporte papel a través de disposiciones de carácter general publicadas en un diario oficial ${ }^{55}$.

En relación con los ficheros y tratamientos no automatizados anteriores a la $\angle O P D$, se puede afirmar que les sería de aplicación estrictamente la Disposición Adicional Primera — segundo párrafo- de esta ley, por lo que su adecuación a la LOPD deberá cumplirse el 24 de octubre de 2007. Las obligaciones mencionadas expresamente en esta Disposición Adicional Primera son las referidas a la declaración del fichero, a través de la disposición de carácter general o de la adaptación de la existente y su comunicación a la Agencia Española de Protección de Datos. Las medidas de seguridad a implantar en estos ficheros deben ser establecidas por un reglamento de medidas de seguridad para los ficheros manuales, que debe ser aprobado por el Gobierno y que les será de aplicación a partir de esa fecha. Los derechos de acceso, rectificación y cancelación por parte de los afectados pueden ser ejercidos sin esperar a esa fecha, ya que ese plazo es "sin perjuicio" del ejercicio de estos derechos. No dice nada en relación con la vigencia de los principios de calidad, información, consentimiento, datos especialmente protegidos, deber de secreto y comunicación de datos. La lógica implicaría que deberían aplicarse a partir de la aprobación de la LOPD sin esperar a la finalización del plazo, dado su vinculación íntima con los derechos de acceso, rectificación y cancelación. No tiene sentido afirmar el derecho de rectificación y cancelación si no se admite el

54 Así, de los 11.311 ficheros declarados por la Administración de la Comunidad de Madrid, 5.246 corresponden a ficheros manuales. Cfr. Memoria de la Agencia de Protección de Datos de la Comunidad de Madrid 2005. Se ha solicitado la inscripción de los ficheros manuales de la Administración de la Comunidad de Madrid en el Registro General de Protección de Datos.

${ }_{55}$ Cfr. Manual de Protección de Datos para las Administraciones Públicas, Civitas-APDCM, Madrid, 2003, págs. 84-89. 
principio de consentimiento o el principio de calidad. Tampoco parece posible separar el derecho de acceso del principio de información acerca del tratamiento de datos personales ${ }^{56}$.

De lo dicho se podrían sacar las siguientes conclusiones en relación con la vigencia de la normativa de protección de datos personales a los ficheros manual-estructurados, a partir de criterios de hermenéutica constitucional. La zona de certeza sería la vigencia para los tratamientos de datos personales en soporte papel de los principios de protección de datos y de los derechos de acceso, rectificación y cancelación. La zona de certeza negativa estaría formada por la normativa de seguridad, que no sería de aplicación a los ficheros manuales, bien por inexistencia de esa normativa en el caso de los ficheros manuales posteriores a la LOPD, bien por imposibilidad de aprobar ésta hasta el 2007 en el caso de los ficheros manuales preexistentes a la LOPD. Ha existido una zona de incertidumbre acerca de la obligación de declaración de los ficheros manuales y de inscribirlos en los Registros de Protección de Datos Personales. No obstante, nosotros consideramos la obligación de declaración y de inscripción de los ficheros manual-estructurados, tanto de aquellos posteriores a la LOPD como de los preexistentes, éstos últimos a partir del 24 de octubre de 2007.

Analizada esta realidad, es necesario manifestar una preocupación por la seguridad de los ficheros manuales - por ejemplo, de expedientes académicos- de los centros universitarios, la mayoría de ellos anteriores a la entrada en vigor de la LOPD. Lógicamente, como ya hemos señalado en alguna otra ocasión, la mejor manera de velar por la seguridad de los tratamientos de datos personales en soporte papel es su migración a soporte informático, ya que la informática permite la adopción de un conjunto de medidas de seguridad previstas en el Real Decreto 994/1999, de 11 de junio, que aprueba el Reglamento de Medidas de Seguridad de los ficheros automatizados que contengan datos de carácter personal, además de facilitar la rapidez y la eficiencia en la gestión. Por eso, parece lo más conveniente que los centros universitarios utilicen el periodo transitorio para migrar la información de los ficheros manuales a ficheros automatizados dentro de un proceso más amplio de implantación de la Administración electrónica. Mientras tanto, es necesario ir implantando protocolos de custodia de los ficheros

56 No obstante, también se puede afirmar que los principios de protección de datos son distintos a los derechos y la vigencia de los primeros se encuentra diferida en virtud de la referencia en la Disposición Adicional Primera - «su adecuación a la presente Ley Orgánica»- al año 2007. 
manual-estructurados en los centros universitarios. Así, por ejemplo, los expedientes académicos en papel se deben encontrar bajo llave y no todo el personal de secretaría debe tener acceso a ellos. En todo caso, una falta de custodia de información personal almacenada en papel puede suponer también una vulneración del deber de secreto, principio de protección de datos recogido en el art. 10 LOPD ${ }^{57}$. Por ello, los responsables de fichero deben conservar la información personal con unos criterios de custodia y archivo que permitan la confidencialidad de estos datos personales ${ }^{58}$.

\section{f) La autoridad de control competente sobre los tratamientos de datos personales de las Universidades}

La distribución de competencias entre la autoridad estatal de control y las autoridades de las comunidades autónomas se encuentra descrita en el art. 41 LOPD. Este artículo señala que "[I]as funciones de la Agencia de Protección de Datos reguladas en el art. 37 [...] serán ejercidas, cuando afecten a los ficheros de datos de carácter personal creados o gestionados por las Comunidades Autónomas y por la Administración Local de su ámbito territorial, por los órganos correspondientes de cada Comunidad, que tendrán la consideración de autori-

57 El derecho fundamental a la protección de datos no solo puede ser tutelado a través del procedimiento administrativo previsto en la Ley 15/1999, de 13 de diciembre. También cabe instar la garantía jurisdiccional civil prevista en la Ley Orgánica 1/1982, de 5 de mayo, de protección civil del derecho al honor, a la intimidad personal y familiar y a la propia imagen o la protección penal prevista en el Título $X$ del Código Penal «Delitos contra la intimidad, el derecho a la propia imagen y la inviolabilidad del domicilio». No obstante, en este último supuesto hay que valorar también la falta de tipicidad.

58 Esta preocupación se encuentra también extendida en el ámbito sanitario y en los servicios sociales donde se generan y conservan historias clínicas e historias sociales en soporte papel. La aparición de estas historias en algunas ocasiones abandonadas ha generado alarma social que se ha trasladado a los medios de comunicación. Por ello, la Agencia de Protección de Datos de la Comunidad de Madrid aprobó la Recomendación 2/2004, de 30 de julio, sobre custodia, archivo y seguridad de los datos de carácter personal de las historias clínicas no informatizadas. Esta Recomendación aborda cuestiones tales como el archivo y custodia del fichero de historias clínicas, su seguridad, la conservación y expurgo de la historia clínica y las cesiones de datos de la historia clínica. También se aprobó la Recomendación 1/2005, de 5 de agosto, sobre Archivo, Uso y Custodia de la Documentación que compone la Historia Social no informatizada por parte de los Centros Públicos de Servicios Sociales de la Comunidad de Madrid. 
dades de control, a los que garantizarán plena independencia y objetividad en el ejercicio de su cometido". A tenor del art. 41 LOPD se desprende que el alcance de las competencias de las autoridades de control de las Comunidades Autónomas se extiende, además de a los ficheros de las Entidades Locales, a los ficheros que reúnan una doble condición de ser ficheros de titularidad pública y tener como responsable de esa competencia a una Comunidad Autónoma ${ }^{59}$.

En primer lugar, no hay duda de que los ficheros de las Universidades públicas tienen el carácter de ficheros públicos. La delimitación del carácter público de los tratamientos de datos personales de estas Universidades se deduce de la consideración de Administración Pública de su responsable, sin perjuicio de que no todos sus actos estén sometidos al Derecho Administrativo y sean ejercicio de potestades de Derecho Público. Los ficheros que tengan como titulares a las Universidades Públicas tienen la consideración de ficheros públicos y no de ficheros privados $^{60}$. Las Universidades Públicas no son asociaciones de particulares que desempeñen funciones privadas. Por tanto, todos sus ficheros, también aquellos que se sustancian sobre actividades que no son ejercicio de potestades de Derecho Público, tienen el carácter de ficheros públicos.

Además, para que los ficheros de las Universidades públicas sean competencia de la autoridad autonómica, es necesario que la Universidad pública esté vinculada a una Comunidad Autónoma, es decir, que desarrolle competencias reconocidas para esa Comunidad en su Estatuto de Autonomía y que hayan sido debidamente transferidas a aquélla. Así, se puede afirmar la existencia de una relación de tutela entre la Administración de la Comunidad Autónoma y las Universidades

59 La Agencia de Protección de Datos de la Comunidad de Madrid hizo una consulta a la Agencia Española de Protección de Datos acerca de la posibilidad de que el art. 2.1 del Anteproyecto de Ley de Protección de Datos de la Comunidad de Madrid afirmara que las funciones de la Agencia de Protección de Datos de la Comunidad de Madrid se ejercerán sobre los ficheros «creados o gestionados por las Universidades Públicas. El Informe, de 21 de mayo de 2001, de la Agencia Española de Protección de Datos fue afirmativo.

60 Como hemos señalado anteriormente, no nos encontramos, en este caso, con la necesidad de distinguir entre actividad administrativa y actividad privada para delimitar entre ficheros públicos y ficheros privados. Este supuesto se produce en las Corporaciones de Derecho Público ya que, por su carácter mixto o bifronte, son a la vez Administración Pública que desempeña funciones administrativas a través de ficheros públicos y asociación de particulares que desarrolla funciones privadas a través de ficheros privados. Cfr. Guía de Protección de Datos para Colegios Profesionales, Civitas, Madrid, 2004, págs. 11-14. 
públicas de su territorio. La Ley Orgánica 11/1983, de 25 de agosto, de Reforma Universitaria estableció en su momento los supuestos en los que la actuación de las Universidades quedaría sujeta al control de las Comunidades Autónomas. Así, el art. 3.3 atribuía a cada Comunidad Autónoma la tarea de coordinación de las Universidades de su competencia. De esta forma, la Universidades públicas y privadas se creaban modificaban o suprimían por normas de las propias Comunidades Autónomas - arts. 9 y 10 -. Este criterio ha sido mantenido por la Ley Orgánica 6/2001, de 21 de diciembre, de Universidades que atribuye a las Comunidades Autónomas la coordinación de las Universidades de su competencia, sin perjuicio de las funciones del Consejo de Coordinación Universitaria - art. 2.5 LOU-. Así, la LOU ha incrementado las facultades autonómicas de coordinación y gestión, al añadir a las competencias originarias otras facultades como la regulación del régimen jurídico y retributivo del profesorado contratado ${ }^{61}$, la capacidad para establecer retribuciones adicionales para el profesorado, la aprobación de programas de financiación plurianual conducentes a contratos programa y la evaluación de la calidad de las Universidades en el ámbito de su responsabilidad.

Un ejemplo a este respecto puede ser el de la propia Comunidad de Madrid. El apartado B del Acuerdo de traspaso de funciones y servicios de la Administración del Estado a la Comunidad de Madrid en materia de Universidades, aprobado por Real Decreto 942/1995, de 9 de junio, prevé en su número primero que "se traspasan a la Comunidad de Madrid las Universidades Complutense, Politécnica, Autónoma, Alcalá de Henares y Carlos III", habiendo sido creada por la Ley 7/1996, de 8 de julio, de la Asamblea de Madrid, la Universidad Rey Juan Carlos ${ }^{62}$. Esta transferencia se efectúa en desarrollo de lo establecido en el artículo 29.1 del Estatuto de Autonomía de la Comunidad de Madrid, según el cual "[c]orresponde a dicha Comunidad Autónoma la competencia de desarrollo legislativo y ejecución de la enseñanza en toda su extensión, niveles y grados, modalidades y especialidades, de acuerdo con lo dispuesto en el artículo 27 de la Constitución y leyes orgánicas

61 Así, por ejemplo, el Decreto 153/2002, de 12 de septiembre, del Consejo de Gobierno de la Comunidad de Madrid regula el régimen del personal docente e investigador contratado por las Universidades Públicas de Madrid y su régimen retributivo.

62 Con anterioridad, el Real Decreto 557/1991, de 12 de abril, traspasó a las Comunidades Autónomas las competencias de creación, supresión, adscripción e integración de Facultades, Escuelas Universitarias y demás centros universitarios cuya creación no corresponda a la Universidades. 
que conforme al apartado 1 del artículo 81 de la misma lo desarrollen, y sin perjuicio de las facultades que atribuye al Estado el número $30 \mathrm{del}$ apartado 1 del artículo 149 y de la Alta Inspección para su cumplimiento y garantía» ${ }^{63}$.

El Acuerdo de Transferencia dispone además que «corresponde a la Comunidad Autónoma las funciones y competencias derivadas de su Estatuto de Autonomía y las que, en materia de enseñanza superior atribuye a las Comunidades Autónomas la Ley Orgánica 11/1983, de 25 de agosto, de Reforma Universitaria y, en particular, las siguientes: a) La creación, supresión, adscripción e integración, según corresponda, de Facultades, Escuelas Técnicas Superiores, Escuelas Universitarias, Institutos Universitarios, Colegios Universitarios, así como aquellos otros centros universitarios cuya creación no corresponda a la Universidad; b) La gestión, de acuerdo con los criterios establecidos por la Administración del Estado, de las becas y ayudas al estudio universitario correspondientes a las convocatorias del Ministerio de Educación y Ciencia; c) La gestión de las exenciones parciales o totales del pago de las tasas académicas acordadas por el Estado".

Así, las facultades de tutela sobre las Universidades Públicas del territorio de la Comunidad de Madrid le corresponden a la Administración Autonómica, sin perjuicio de la autonomía reconocida por la Ley Orgánica de Reforma Universitaria ${ }^{64}$. De hecho, existe una Ley 4/1998, de 8 de abril, de Coordinación Universitaria de la Comunidad de Madrid. Y, recientemente se ha aprobado la Ley 12/2002, de 18 de diciembre, que regula los Consejos Sociales de las Universidades Públicas de Madrid.

Por ello, la Agencia Española de Protección de Datos ha señalado que "las Universidades Públicas situadas en el territorio de la Comunidad de Madrid son Administraciones Públicas cuya tutela y control corresponde a la propia Comunidad, pudiendo considerar a las mismas comprendidas en el art. 41.1 de la Ley Orgánica 15/1999, ejerciendo las

63 El Estatuto de la Comunidad de Madrid no contenía inicialmente ninguna referencia competencial singular a las Universidades. Sobre la base de la Ley Orgánica de Transferencia a las Comunidades Autónomas de 1992, se incluyó esta competencia en virtud de la reforma del Estatuto de Autonomía de la Comunidad de Madrid efectuado a través de la Ley Orgánica 10/1994, de 24 de marzo.

${ }^{64}$ Cfr. J. LóPEZ-MEdel BÁsCONES, "Las competencias en materia de cultura, educación y deporte", en E. ARNALDo, Comentarios al Estatuto de Autonomía de la Comunidad de Madrid, Consejería de Justicia y Administraciones Públicas, 2003, págs. 858-860. 
potestades de control sobre sus ficheros la Agencia de Protección de Datos de la Comunidad de Madrid sin perjuicio de las competencias que el art. 41.1 de la Ley Orgánica reserva a esta Agencia de Protección de Datos" ${ }^{65}$.

Por tanto, si la delimitación competencial entre la Agencia Española de Protección de Datos y las Agencias Autonómicas está en la frontera entre lo público y lo privado ${ }^{66}$, se puede afirmar que los ficheros con datos personales de las Universidades Públicas son competencias de las Agencias Autonómicas —en el supuesto de que lo prevea su Ley de creación- al ser Entidades de Derecho Público con personalidad jurídica propia vinculadas o dependientes de una Administración territorial y que desarrollan competencias transferidas a una Comunidad Autónoma. En cambio, los ficheros de las Universidades Privadas son competencia inicialmente de la Agencia Española de Protección de Datos. Esto es así porque éstas son entidades privadas — no tienen el carácter de Administraciones Públicas-, sus ficheros no son públicos sino privados y todos los ficheros privados son competencia de la Autoridad Estatal de control. Así, como hemos señalado, sus ficheros no son creados a través de disposiciones de carácter general sino que son notificados a la Agencia Española. Esta es la distribución competencial que se refleja en la Ley 8/2001, de 13 de julio, de Protección de Datos Personales de la Comunidad de Madrid - art. 2.1- y en la Ley Vasca 2/2004, de 25 de febrero, de Ficheros de Datos de Carácter Personal de Titularidad Pública y de Creación de la Agencia Vasca de Protección de Datos.

Esta delimitación competencial no está exenta de problemas. Es verdad que la Administración de cada Comunidad Autónoma ejerce una función de control sobre las Universidades Privadas de su ámbito territorial, en virtud de las previsiones de los distintos Estatutos de Autonomía y de la legislación ${ }^{67}$. Así, las Universidades Privadas han

65 Informe de 21 de mayo de 2001, ya citado.

${ }^{66}$ A excepción del control de los ficheros de la Administración General del Estado, que, a pesar de tener el carácter de ficheros públicos, son competencia de la Agencia Española de Protección de Datos, lógicamente al no ser competencia transferida a las Comunidades Autónomas.

${ }^{67}$ Además, la LOU ha atribuido a las CCAA una función de control y supervisión sobre los actos y negocios jurídicos que modifiquen la personalidad jurídica o la estructura de una Universidad privada o que impliquen la transmisión o cesión, intervivos, total o parcial, a título oneroso o gratuito, de la titularidad directa o indirecta de las personas físicas o jurídicas ostenten sobre las universidades privadas 0 centros universitarios privados adscritos a Universidades públicas -art. 5-. 
sido reguladas por Ley ${ }^{68}$. Por ese motivo, la Ley 5/2002, de 19 de abril, de la Agencia Catalana de Protección de Datos ha incluido dentro de las competencias de esa Agencia Autonómica el control de los ficheros de las Universidades "del ámbito territorial de Cataluña" -art. 3.1-, sin distinguir entre Universidades Públicas y Privadas ${ }^{69}$. Lo mismo hace el Estatuto de Autonomía de Cataluña que en su art. 156 atribuye a la Generalitat todos los ficheros y tratamientos creados o gestionados por las Universidades que integran el sistema universitario catalán. Realmente, como hemos podido señalar en otra ocasión, la diferenciación entre lo público y lo privado no es a simple vista evidente ${ }^{70}$. En esa dirección la Ley 5/2002, de 19 de abril, y el Estatuto de Cataluña han dado un paso más, extendiendo la competencia de esa Agencia $-y$, lógicamente, restándosela a la Agencia Española- a algunos ámbitos de frontera. Así, si la legislación de la Comunidad de Madrid y del País Vasco han extendido la competencia de las Agencias Autonómicas únicamente a las personas jurídicas públicas ${ }^{71}$, la Ley 5/2002, de 19 de abril -art. 3.2 - establece que "[l]a Agencia Catalana de Protección de Datos también ejerce sus competencias con relación a los ficheros creados por las administraciones, los organismos y las entidades a que se refiere el apartado 1 cuando sean gestionados por entidades públicas o

68 Para el ámbito de la Comunidad de Madrid, hay que señalar las leyes 23 y 24/1995, de 17 de julio, de reconocimiento de la Universidad Antonio de Lebrija y la Universidad Europea de Madrid, la Ley 18/1998, de 20 de noviembre, de reconocimiento de la Universidad Camilo José Cela, la Ley 7/2001, de 3 de julio, de reconocimiento de la Universidad Francisco de Vitoria y la ley 1/2006, de 14 de junio, de $R e-$ conocimiento de la Universidad Privada "Universidad a Distancia de Madrid». En todo caso, la Ley 8/2001, de 13 de julio, de Protección de Datos de Carácter Personal de la Comunidad de Madrid ha optado por considerar estos ficheros como privados, y, por tanto, sometidos a control por la Agencia Española de Protección de Datos.

69 Una de las principales razones para esta delimitación competencial es atribuir a la Agencia Catalana de Protección de Datos el control sobre la Universidad Abierta de Cataluña, una Fundación privada de iniciativa pública. Otras Universidades Privadas de Cataluña que controlaría la Agencia Catalana son la Universidad de Vic, la Universidad Ramón LLull, la Universidad Abad Oliva y la Universidad Internacional de Cataluña.

70 Cfr. A. Troncoso Reigada, Privatización, Empresa Pública y Constitución, Marcial Pons, Madrid, 1997, págs. 37-42.

71 La Ley 8/2001, de 13 de julio, ha diferenciado los sujetos públicos de los sujetos privados a partir de la forma jurídica de personificación —art. 2-. Así, sólo serán Administraciones Públicas las Administraciones territoriales -autonómica y local-, la Administración Corporativa y la Administración Institucional, incluyendo en ésta sólo a los Entes públicos - forma jurídica pública-y excluyendo de ésta a las sociedades mercantiles públicas — forma jurídica privada—. 
privadas en la prestación de servicios públicos, sean o no concesionarias de éstos, o por asociaciones o fundaciones, o por las sociedades civiles o mercantiles en las cuales la Generalidad o los entes locales tengan la participación mayoritaria del capital, cuando llevan a cabo actividades por cuenta de una administración pública». Esto significa que la Agencia Catalana extiende su ámbito de control también a entidades privadas que presten servicios públicos aunque no sean concesionarios de éstos, y a las sociedades civiles o mercantiles de participación pública mayoritaria, cuando éstas lleven a cabo una actividad por cuenta de una Administración Pública y gestionen ficheros creados por las Administraciones Públicas catalanas. Estas entidades, que podrían ser consideradas encargadas del tratamiento de ficheros públicos, serían controladas por la Agencia Catalana ${ }^{72}$.

La atribución del control de los ficheros de las Universidades Privadas a las Agencias Autonómicas plantea algunos problemas. Así, si bien estos ficheros son objeto de control por la Agencia Catalana, al tener el carácter de privados, tienen que ser creados a través de una notificación a la Agencia Española de Protección de Datos -art. 25 LOPD-. La Agencia Española ejerce un control material en el procedimiento de inscripción de los ficheros privados, no ocurriendo lo mismo con los ficheros públicos ${ }^{73}$. Podría existir, por tanto, una doble instancia de control sobre los ficheros de las Universidades Privadas, y una divergencia de criterios que puede ocasionar conflictos en la práctica ${ }^{74}$. Igualmente, como ya hemos señalado, al existir diferencias en el régimen de infracciones y sanciones entre las Universidades Públicas -los ficheros públicos- y las Universidades Privadas - los ficheros priva-

72 El Estatuto de Cataluña amplia el techo competencial. Su análisis lo dejamos para otro estudio específico.

${ }^{73}$ El Real Decreto 1332/1994, de 20 de junio, por el que se desarrollan determinados aspectos de la Ley Orgánica 5/1992, de 29 de octubre, de regulación del tratamiento automatizado de los datos de carácter personal —en vigor- establece que la persona o entidad que pretenda crear un fichero de datos de carácter personal lo notificará previamente a la Agencia de Protección de Datos. El Director de la Agencia Española, a propuesta del Registro General de Protección de Datos, acordará la inscripción de los ficheros de titularidad privada «si la notificación contuviera la información preceptiva y se cumplen las restantes exigencias legales, requiriendo, en caso contrario, al responsable del fichero para que la complete o subsane en el plazo de diez días, con indicación de que, si así no lo hiciera, se le tendrá por desistido de su petición, archivándose sin más trámite" —arts. 6 y 7 -.

74 Una posible solución sería la creación del fichero de la universidad privada través de una disposición de carácter general de la Consejería que tuviera las competencias sobre universidades. 
dos-, la competencia de control de la Agencia Catalana sobre los ficheros de las Universidades Privadas obligaría a ésta a aplicar las sanciones económicas establecidas en la legislación por incumplimientos de la legislación por parte del responsable de ficheros privados - art. 45 LOPD_-, a menos que se entienda que estas Universidades Privadas son Administraciones Públicas en sentido material y sus ficheros se consideren ficheros públicos. En todo caso, el modelo competencial catalán aporta ventajas en el control por parte de la Agencia Catalana de ficheros creados por la Administración de la Generalitat pero gestionados por las Universidades privadas.

\section{LA PUBLICACIÓN DE DATOS DE PROFESORES.}

a) La publicación de datos de profesores relativos al pago de complementos retributivos por las Comunidades Autónomas. La publicación de datos relativos a los procedimientos de evaluación de la actividad investigadora, a la habilitación, a la acreditación y al acceso a la función pública del profesorado

La Administración educativa ha puesto en marcha distintos tratamientos de datos personales de profesores que han sido obtenidos a partir de las solicitudes de complemento retributivo autonómico ${ }^{75}$. Como hemos señalado, la primera obligación cuando se va a recabar datos personales, en este caso de docentes universitarios, es proceder a la declaración del fichero a través de una disposición de carácter general, publicar la disposición e inscribir los ficheros en los registros correspondientes $^{76}$. Además, la Administración Educativa debe respetar todos los principios y los derechos de protección de datos, entre los que podríamos destacar el principio de calidad.

75 Cfr. la Orden 3031/2005 de la Consejería de Educación de la Comunidad de Madrid que reguló el procedimiento de concesión para el 2005 del complemento autonómico por méritos individuales del personal docente e investigador de las Universidades Públicas de la Comunidad de Madrid. La Agencia de Protección de Datos de la Comunidad de Madrid declaró tres infracciones graves a la Consejería de Educación. De esta Resolución se hicieron eco los medios de comunicación —cfr. El País, 15 de septiembre de 2006-.

76 No valdría, por ejemplo, tener declarado un fichero de docencia en educación superior que contenga datos de docentes universitarios pero que no contemple la finalidad de este nuevo tratamiento para la asignación de un complemento retributivo en el marco de un procedimiento de concurrencia competitiva. 
El principio de calidad exige que la finalidad del tratamiento sea legítima, es decir, que entre dentro de las competencias del organo administrativo, es decir, dentro de su reserva de Administración. Es una finalidad legítima de una Consejería de Educación y de una Dirección General de Universidades el establecimiento de un sistema retributivo a profesores de universidad, no de manera lineal sino en virtud del cumplimiento de algunos objetivos: dedicación a la universidad, grupos de investigación a los que se pertenece, sexenios, quinquenios, etc. En todo caso, los datos que se recaben deben ser adecuados y pertinentes para el cumplimento de la finalidad. Así, sólo se pueden tratar aquellos datos que se vayan a utilizar como criterios para dar o no el complemento. Por tanto, no se pueden recabar en los impresos datos personales de los profesores que no tengan que ver con la adjudicación del complemento retributivo ${ }^{77}$. El principio de calidad también prohíbe el tratamiento de datos para finalidades incompatibles. El principio de finalidad exige que los datos personales se traten siempre para la finalidad para la cual se han recabado y no para finalidades distintas. Así, los docentes dan sus datos para solicitar un complemento retributivo por lo que éstos no pueden ser utilizados para una finalidad distinta e incompatible, por ejemplo, la concesión de becas para alumnos con expedientes académicos excelentes.

El principio de información exige que los solicitantes sean informados de manera expresa, precisa e inequívoca de que sus datos van a formar parte de un fichero, de la finalidad de la recogida de datos, de los destinatarios de la información, de la posibilidad de ejercitar los derechos de acceso, rectificación, cancelación y oposición y de la identidad y dirección del responsable del fichero. Debe existir una leyenda informativa en las solicitudes en papel o en web del complemento retributivo.

El aspecto más problemático es la publicación de los resultados de este procedimiento en una página web en Internet, lo que supone una comunicación de datos a terceras personas. El art. 59.5 b) de la Ley 30/1992, de 26 de noviembre, de Régimen Jurídico de las Administraciones Públicas y del Procedimiento Administrativo Común establece que la notificación del acto administrativo, cuando se trate de actos integrantes de un procedimiento selectivo o de concurrencia competitiva de cualquier tipo, se realizará mediante la publicación del acto. La pu-

77 Así, una Administración educativa no puede utilizar la solicitud de complemento retributivo para obtener datos personales de los profesores que no le facilitan las Universidades. Esto supondría un tratamiento de datos excesivo. 
blicación de los listados de personas que estén participando en un proceso selectivo o de concurrencia competitiva ante cualquier Administración Pública no es potestativa sino obligatoria en cumplimiento del principio de publicidad que rige todas las convocatorias de pruebas selectivas, de acuerdo con las bases de las mismas. Así, las bases de la convocatoria deberán indicar el tablón de anuncios o medio de comunicación donde se vayan a realizar las sucesivas publicaciones, careciendo de validez las que se lleven a efecto en lugares distintos ${ }^{78}$.

La publicación se podrá hacer también en sitios web. Así, el art. 45 de la Ley 30/1992, de 26 de noviembre, establece que las Administraciones Públicas impulsarán el empleo y aplicación de las técnicas y medios electrónicos, informáticos y telemáticos, para el desarrollo de su actividad y el ejercicio de sus competencias, con las limitaciones que la utilización de estos medios establecen la Constitución y las Leyes $^{79}$. La publicación de estos listados en sitios web es un mecanismo válido de notificación de actos administrativos, que es equiparable al tablón de anuncios. En la sociedad de la información, la web cumple la función que antes desarrollaban los boletines oficiales. Lo que se publica en un boletín oficial, se puede publicar en la web - de hecho se publica ya en la web-. En todo caso, las bases de la convocatoria deben hacer constar esta forma de publicación, precisando el tablón de anuncios o la dirección web y garantizando también el principio de información para el tratamiento automatizado de datos de carácter personal -art. 5 LOPD-.

La finalidad de la publicación de cualquier listado con datos personales de los integrantes de un proceso selectivo es tanto servir de notificación del acto administrativo al interesado como garantizar el principio de publicidad de un procedimiento de concurrencia competitiva y la transparencia de la actividad administrativa. Como hemos señalado, la Ley 30/1992, de 26 de noviembre establece que la publicación del resultado final es la regla general en los procedimientos selectivos o de concurrencia competitiva. Los procedimientos selectivos se caracterizan por existir una pluralidad de solicitantes y un número de plazas limitadas que se otorgan en virtud de unos requisitos que se computan o va-

78 Cfr. J. González Pérez y F. González Navarro, Comentarios a la Ley de Régimen Jurídico de las Administraciones Públicas y Procedimiento Administrativo Común, cit. págs. 1558-1576.

79 Esta norma fue desarrollada en primera instancia a través del Real Decreto 263/1996, de 16 de febrero, por el que se regula la utilización de técnicas electrónicas, informáticas y telemáticas por la Administración General del Estado. Cfr. La informática en las Administraciones Públicas. Informe IRIA-94, MAP, Madrid, 1995. 
loran. Ejemplos de procedimientos selectivos son las oposiciones, el procedimiento de acceso a la Universidad o la concesión de Premios Extraordinarios. Otros procedimientos de concurrencia competitiva son las subvenciones, donde existen una pluralidad de solicitantes y un número de créditos limitados que se asignan en virtud de unos requisitos. La concesión de complementos retributivos para profesores es un procedimiento de concurrencia competitiva ya que existe un elevado número de solicitantes a los que se les asigna unos créditos limitados a partir de unos criterios. Es competitivo porque la asignación de los créditos no es fija sino que depende de los propios méritos y de los demás solicitantes. Es, por tanto, un procedimiento semejante al de las subvenciones $^{80}$. En cambio, como veremos más adelante, la calificación de los alumnos no es un procedimiento de concurrencia competitiva.

La afirmación de que el procedimiento de concesión del complemento retributivo es de concurrencia competitiva tiene consecuencias en relación con el principio de publicidad. La regla general en el procedimiento selectivo o de concurrencia competitiva es la publicación de la resolución. La publicación cumple dos funciones: notificación a una pluralidad abierta de interesados; garantía del principio de transparencia administrativa: que la gente conozca el resultado final, pueda reclamar el expediente y lo pueda impugnar. Por ello, es legítimo publicar la resolución del procedimiento en tablones de anuncios, en boletines oficiales y en páginas web. La publicación de la resolución supone una cesión de datos a terceras personas. No obstante, no se precisa el consentimiento del interesado ya que existe una habilitación legal, la Ley 30/1992, de 26 de noviembre.

No obstante, he de señalar que si bien es legítima la publicación de los resultados finales de los procedimientos selectivos o de concurrencia competitiva en boletines oficiales o en la web, es aconsejable limitar en la medida que sea posible la utilización de estos medios. Se trata de ser más restrictivos, ya que la publicación de un dato personal en una web en Internet abre el acceso al mismo a cualquier persona en cualquier país. Lo que se publica en un boletín oficial hace que esos datos se encuentren eternamente en Internet. La Ley 30/1992, de 26 de noviembre, permite limitar la publicidad cuando esto afecte a la intimidad de las personas. El problema está en que muchas veces estos datos - por ejemplo el DNI-son datos personales no íntimos. En todo caso, en el equilibro de intereses entre el derecho fundamental a la protec-

80 En todo caso, es complejo explicar que un complemento retributivo ordinario anual se rija por la ley de subvenciones. 
ción de datos y el principio de transparencia administrativa, el criterio sería limitar el acceso en web a las personas que tuvieran un interés legítimo en el procedimiento administrativo, interés legitimo interpretado en sentido amplio en virtud del principio constitucional pro actione, pero impidiendo el acceso a personas que no tuvieran ningún interés en el procedimiento administrativo. De esta forma se respetarían tanto el derecho fundamental a la protección de datos como los bienes jurídicos que respaldan la publicidad: la notificación a una pluralidad de interesados, el principio de transparencia administrativa entre aquellos que han concurrido al procediendo administrativo. Sin embargo, la publicación abierta en internet de los resultados permite un acceso indiscriminado de terceros no interesados en el procedimiento y que no han concurrido y puede afectar al derecho fundamental a la protección de datos personales. Por consiguiente, se debería recomendar la no publicación de los resultados de manera abierta en la web como mejor práctica para evitar el acceso por parte de personas ajenas al procedimiento administrativo ${ }^{81}$.

El derecho fundamental a la protección de datos puede ceder cuando haya otro derecho fundamental en presencia -libertad sindical, derecho de participación- pero no en virtud de un principio genérico de transparencia administrativa. En otros supuestos - por ejemplo, la utilización del padrón municipal-, hemos justificado la limitación del derecho fundamental a la protección de datos personales, permitiendo el tratamiento del dato de la edad por la Administración para desarroIlar la actividad prestacional pública de garantía de otros derechos fundamentales ${ }^{82}$. Es una limitación razonable al derecho fundamental a la protección de datos personales: no se trata de ceder información personal indiscriminadamente a terceros sino de permitir la utilización de datos personales que están en poder de la Administración para finalidades compatibles. Se puede incluso estudiar la posibilidad de seguir

81 Este es el criterio que se sigue muy ampliamente en España cuando se publican en web con claves para los interesados los resultados parciales de oposiciones o cuando se publican en el boletín oficial solo las personas que han aprobado unas oposiciones, no las que han suspendido. Por ejemplo, una persona que trabaje en un despacho de abogados o en una consultora y que pretenda entrar en la Administración en un cuerpo de Técnico Superior de Administración Civil del Estado o de Tecnologías de la Información puede sentirse gravemente perjudicado si una persona - por ejemplo, su jefe en el despacho-, que no tiene ningún interés en el procedimiento administrativo ni en su transparencia, conoce a través de internet su participación en el mismo.

82 Cfr. A. Troncoso Reigada, "Introducción» en Guía de Protección de Datos Personales para Ayuntamientos, Civitas, 2004. 
avanzando en la interpretación del principio de calidad, facilitando las comunicaciones de datos internas en la Administración —no cesiones indiscriminadas a terceros- para permitir el conocimiento por parte de un servicio social de un Ayuntamiento de un dato de adicción a drogas de un menor que conoce la policía local para promover acciones de salud pública y de servicios sociales. Incluso se puede justificar la publicación de listados de profesionales autónomos en webs de la Administración, lo que supone una levísima limitación del derecho fundamental a la protección de datos de estas personas - que quieren realmente esta publicación pues ejercen una actividad profesional-, permitiendo al mismo tiempo que la Administración desarrolle una función administrativa de ordenación profesional que evita el intrusismo. Sin embargo, en el supuesto objeto de análisis, la publicación de datos personales de profesores en una web abierta a personas que no tienen ningún interés legítimo en el procedimiento afecta a derechos fundamentales. No obstante, como hemos señalado antes, este planteamiento se puede hacer únicamente en términos de recomendación o de propuesta de lege ferenda. No hay duda de que existe una habilitación legal que permite la publicación de la resolución de un procedimiento de concurrencia competitiva sin el consentimiento de los interesados tanto de manera abierta en Internet como en un boletín oficial.

Ahora bien, es muy importante determinar el contenido de la publicación. La habilitación legal para la publicación afecta sólo a la resolución, que debe ser entendida como el resultado final —nombre y apellidos y puntos totales-y no a todos los criterios o requisitos que hacen falta para alcanzar la resolución. El hecho de que una Resolución debe estar siempre motivada no implica la publicidad de la motivación. En todo caso, la publicidad de la motivación debe extenderse únicamente a quien ostente un interés legítimo, no de manera abierta y universal. No se deben publicar, por tanto, todos los elementos que conforman la fórmula aritmética que sirve para determinar el complemento retributivo: proyectos de investigación, sexenios relativos, quinquenios, situación en la Universidad, etc. Esto equivale a publicar todo el expediente administrativo. Lo que se publica habitualmente en las oposiciones a través de Boletines Oficiales es el listado definitivo de ingresos; no de no ingresados y no de la puntación obtenida en cada una de las pruebas, los puntos por antigüedad, etc. La publicación de datos excesivos en Internet supone una cesión de datos sin habilitación legal y sin consentimiento del interesado.

El principio de calidad exige también que se cancelen los datos cuando hayan dejado de ser necesarios y pertinentes para la finalidad. Si la finalidad de la publicación es la notificación a una pluralidad de in- 
teresados y que se puedan conocer y eventualmente impugnar las posibles arbitrariedades en el procedimiento, la publicación debe cancelarse cuando haya finalizado el plazo de impugnación. La ausencia de cancelación supone una vulneración del principio de calidad.

Por tanto, es legítimo que la Administración ponga en marcha un complemento retributivo de profesores no lineal sino de una manera que fomente la investigación, con la finalidad de mejorar a las Universidades y poner a los profesores a competir, siempre que se haga con arreglo a unos criterios: debe declararse el fichero, deben tratarse únicamente aquellos datos adecuados y pertinentes; la publicación de la resolución — de su resultado final - tiene amparo legal y es legítima ya que tiene la finalidad de favorecer la transparencia administrativa y proceder a la notificación de los interesado. En todo caso, es recomendable que el acceso lo pueda hacer quien tenga un interés legítimo, es decir, aquellas personas que están dentro del procedimiento y que quieren evitar cualquier arbitrariedad en el mismo.

Lo que no es legítimo es la publicación de datos excesivos, la no cancelación de la publicación de la información una vez finalizado el plazo de alegaciones y la utilización de la información personal de los profesores para finalidades distintas a la concesión del complemento retributivo. La comisión de estas infracciones trae a la luz lo que puede estar detrás: la publicidad no está orientada a alcanzar una mayor transparencia en un procedimiento de concurrencia competitiva en la asignación de un complemento retributivo. La publicidad está orientada a la competencia entre Universidades. Esto revela que se quiere fomentar la competitividad, no con el complemento, sino con la publicidad $^{83}$. La publicidad está orientada a establecer una evaluación pública permanente del profesorado. Esto lesiona el derecho fundamental a la protección de datos de los profesores. La habilitación legal de la publicidad es para unos concretos fines, no para favorecer de manera permanente la competencia. La Administración educativa debe tratar de alcanzar sus objetivos publicando datos disociados por Departamentos o por Universidades, algo que no se suele hacer porque las Universidades son auténticos grupos de presión que se niegan a la difusión de datos globales.

La publicación permanente en Internet o a través de otros medios de información del profesorado universitario supone una cesión de

83 Se quiere evitar la supuesta corrupción en la Universidad, la adjudicación de plazas incorrectas y todos los males universitarios publicando y manteniendo eternamente en la red información personal de los profesores. 
datos personales a terceras personas que exige el consentimiento del interesado o una habilitación legal —art. 11.2.a) LOPD_, como así lo ha entendido la STC 292/2000, de 30 de noviembre. Esto significa, sensu contrario, que esta publicidad sería legítima si se encuentra prevista en una ley sectorial encaminada a alcanzar otros bienes constitucionales respetando el principio de proporcionalidad -como más adelante veremos-. Una atención específica merece el consentimiento del interesado. Hay que preguntarse qué ocurre cuando hay consentimiento del interesado, es decir, cuando al solicitar el complemento retributivo existe una autorización personal para la publicación de todo el expediente administrativo con todos los datos en Internet. Se puede afirmar así que los que solicitan el complemento retributivo conocen la forma de publicación y consienten la cesión de datos. No obstante, hay que señalar que aunque el derecho fundamental a la protección de datos personales sea considerado un derecho a la autodeterminación informativa y el consentimiento del interesado sea un principio esencial, no es el único principio ni el único derecho que conforma el contenido esencial de este derecho fundamental. Todo tratamiento de datos personales debe respetar todos los principios y todos los derechos, en una palabra, todo el ordenamiento jurídico de protección de datos ya que el consentimiento no puede cubrirlo todo. El consentimiento del interesado no convalida un tratamiento de datos personales excesivos más allá de la finalidad-que vulnera el principio de calidad ni una publicación de datos personales del expediente administrativo, no solo del resultado final. En este último caso, para que pueda publicarse información personal que exceda del resultado final del procedimiento no basta con el consentimiento inicial. Este consentimiento es solo para el tratamiento de datos personales con la finalidad de obtener un complemento retributivo y no sirve para legitimar una publicación excesiva. Es necesario pedir un nuevo consentimiento para la publicación del resto de los datos personales, pudiendo el interesado no prestarlo. No es legítimo y no sería un consentimiento libre considerar que el que solicita el complemento retributivo tiene que admitir - so pena de renunciar a éste- una publicación excesiva y eterna de sus datos en Internet. Este consentimiento no sería un consentimiento libre sino viciado ${ }^{84}$.

${ }^{84}$ La asignación de un complemento retributivo a los profesores y el consiguiente tratamiento de sus datos personales para esta finalidad puede hacerse también sin el consentimiento del interesado, al existir en este ámbito una función administrativa que lo excepciona - art. 6.2 LOPD—. La Consejería de Educación podría recabar la información de las Universidades, un supuesto de comunicación de datos sin consentimiento para funciones compatibles u homogéneas -art. 21 LOPD- No obstante, la Consejería de Educación no podría destinar estos datos 
Por ultimo, hay que señalar que la publicación legítima en Internet de los listados de datos de profesores con el resultado final del procedimiento de concurrencia competitiva permite el acceso de cualquier persona pero esto no equivale a que estos listados sean fuentes accesibles al público a los efectos de posteriores tratamientos. Estas fuentes son las tasadas en la LOPD —el censo promocional, los repertorios telefónicos, las listas de personas pertenecientes a grupos profesionales, los diarios y boletines oficiales y los medios de comunicación; art. 3.j) LOPD - La utilización de esta información personal almacenada en sitios web para finalidades distintas o su difusión en servidores distintos a los previstos en la propia convocatoria significaría una vulneración del principio de calidad de los datos - art. 4 LOPD-y del principio de consentimiento, que debe respetarse en cualquier tratamiento de datos personales - art. 6 LOPD— ${ }^{85}$. Ahora bien, si el resultado final se publicase en el Boletín Oficial del Estado, de las Comunidades Autónomas o Provinciales, esta información con los datos de las personas que en ellos figuren sí se convertiría en una fuente de acceso público ${ }^{86}$.

para finalidades distintas — vulneraría el principio de calidad- ni podría dar publicidad a datos de profesores que excedieran del resultado final del procedimiento de concurrencia competitiva.

85 Es aconsejable incluir una leyenda informativa como ésta: «Los listados que se publican en esta página Web, y que contienen datos de carácter personal, se ajustan a la legislación actual de protección de datos y su única finalidad, de conformidad con lo previsto en el artículo 59 de la Ley 30/1992, de 26 de noviembre, de Régimen Jurídico de las Administraciones Públicas y del Procedimiento Administrativo Común, es la de proceder a notificar a cada uno de los aspirantes el contenido del procedimiento selectivo. Estos listados no constituyen fuente de acceso público y no podrán ser reproducidos ni en todo ni en parte, ni transmitidos ni registrados por ningún sistema de recuperación de información, sin el consentimiento de los propios afectados".

86 La publicación de estos listados en los Boletines Oficiales permite que sean éstos fuentes accesibles al público de manera que su consulta pueda ser realizada por cualquier persona. Además es posible el tratamiento de estos datos personales sin consentimiento del interesado - art. 6 LOPD- y su cesión a terceras personas -art. 11 LOPD - Sin embargo, no puede olvidarse que en estos casos el propio artículo 6 LOPD establece que, si bien los datos que figuren en una fuente de acceso público podrán tratarse sin el consentimiento de los afectados, en todo caso el responsable del fichero que obtenga la información de los boletines oficiales deberá cumplir con la obligación de información al afectado establecido en el artículo 5.4 LOPD. "Cuando los datos de carácter personal no hayan sido recabados del interesado, éste deberá ser informado de forma expresa, precisa e inequívoca, por el responsable del fichero o su representante, dentro de los tres meses siguientes al momento del registro de los datos, salvo que ya hubiera sido informado con anterioridad, del contenido del tratamiento, de la procedencia de los datos, así como de lo previsto en las letras a), d) y e) del apartado 1 del presente artículo». 
Merece también un estudio específico la publicación de datos relativos a los procedimientos de evaluación de la actividad investigadora, a la habilitación, a la acreditación y al acceso a la función pública del profesorado. La evaluación de la actividad investigadora no es un procedimiento selectivo ni de concurrencia competitiva ya que no hay un número limitado de sexenios a atribuir, sin perjuicio de que exista una partida presupuestaria a efectos de planificación. No rige aquí el principio de publicidad según lo previsto en la Ley 30/1992, de 26 de noviembre $^{87}$. Muy al contrario, la normativa reglamentaria proclama la confidencialidad de los datos personales de este procedimiento ${ }^{88}$. La Orden Ministerial 2713/2003, de 26 de septiembre, por la que se aprueba el Reglamento de Funcionamiento Interno de la Comisión Nacional Evaluadora de la Actividad Investigadora señala que "de acuerdo con la legislación vigente en materia de protección de datos, la Comisión Nacional de Evaluación de la Actividad Investigadora se compromete al cumplimiento de su obligación de proteger los datos de carácter personal y a tratar los mismos con la confidencialidad que requiera dicha legislación. A estos efectos, adoptará las medidas necesarias para evitar su alteración, pérdida, tratamiento o acceso no autorizado" - art. 17-. Igualmente se establece que "tanto los Comités Asesores como los especialistas deberán mantener la confidencialidad de sus deliberaciones y de los resultados de la evaluación" —art. 13.3-. En todo caso, sí es posible la comunicación de estos datos sin consentimiento de los interesados desde esta Comisión Nacional a otras Administraciones Públicas siempre que se produzca dentro del ámbito del art. 21 LOPD, es decir, para el ejercicio de las mismas competencias o materias. Así, la Orden señala como una de las funciones del Coordinador General de la Comisión la de "suministrar al Ministerio de Educación, Cultura y Deporte, a las Comunidades Autónomas y al CSIC, los datos de evaluación que soliciten en el ámbito de su competencia y de acuerdo con los criterios aprobados por la Comisión Nacional de Evaluación de la Actividad Investigadora» —art. 8.i- ${ }^{89}$.

Lo que sí se publica en el Boletín Oficial del Estado $-\mathrm{y}$, por tanto, pasa a ser una fuente accesible al público- es el listado completo de

87 Que no rija el principio de publicidad y que no sea un procedimiento selectivo o de concurrencia competitiva no limita el acceso de los interesados al expediente administrativo.

${ }^{88}$ Cfr. el Real Decreto 1086/1989, de 28 de agosto, sobre Retribuciones del Profesorado Universitario, reformado por los Reales Decreto 74/2000, de 21 de enero y 1352/2002, de 13 de diciembre.

${ }^{89}$ Así, muchas CCAA establecen complementos retributivos dependientes directamente del número de sexenios de investigación. 
los miembros de los Comités Asesores y de los especialistas que forman parte de la Comisión Nacional de Evaluación de la Actividad Investigadora. Es de aplicación aquí el principio de transparencia administrativa por el cual cualquier ciudadano tiene derecho a identificar al personal bajo cuya responsabilidad se tramiten los procedimientos administrativos - art. 35 de la Ley 30/10992, de 26 de noviembre-. Además, la propia Ley Orgánica 6/2001, de 21 de diciembre, de Universidades establece la publicidad de las listas de profesores que cumplen los requisitos establecidos en la LOU para poder ser miembros de las comisiones juzgadoras de las pruebas de habilitación nacional y de entre los cuales deben seleccionarse por sorteo público aquellos que vayan a componer dichas comisiones ${ }^{90}$.

El procedimiento de habilitación del profesorado establecido en la LOU, así como los procedimientos de acceso a la función pública, son selectivos por lo que rige el principio de publicidad, con los límites antes señalados. Es legítima la publicación de los datos identificativos y de la calificación de los distintos concursantes, publicación que puede hacerse tanto en tablones como en boletines oficiales o en internet. Para los interesados es legítimo el acceso a todo el expediente administrativo con los datos personales de los concursantes. No se precisa el consentimiento del interesado ya que existe una clara habilitación legal. El art. 19.1 de la Ley 30/1984, de 2 de agosto, de Medidas para la Reforma de la Función Pública, establece que "las Administraciones Pú-

90 Así, el art. 57. 4 LOU establece: «4. Las pruebas de habilitación serán juzgadas por Comisiones compuestas por siete profesores del área de conocimiento correspondiente o, en su caso, afines, todos ellos pertenecientes al cuerpo de funcionarios docentes universitarios de cuya habilitación se trate, o de cuerpos docentes universitarios de iguales o superiores categorías. En el caso de que los miembros de las citadas Comisiones sean Profesores Titulares de Escuelas Universitarias, Catedráticos de Escuelas Universitarias o Profesores Titulares de Universidad deberán poseer, al menos, el reconocimiento de un período de actividad investigadora de acuerdo con las previsiones del Real Decreto 1086/1989, de 28 de agosto, de Retribuciones del Profesorado Universitario, o norma que lo sustituya, y de dos de los mencionados períodos si se trata de Catedráticos de Universidad. Los miembros de las Comisiones de habilitación serán elegidos por sorteo público realizado por el Consejo de Coordinación Universitaria y según el procedimiento que reglamentariamente establezca el Gobierno. Actuará de Presidente el Catedrático de Universidad más antiguo o, en su caso, el Profesor Titular de Universidad o Catedrático de Escuelas Universitarias más antiguo. Las pruebas se celebrarán en la Universidad de adscripción del Presidente. En las citadas Comisiones de habilitación, uno de sus miembros podrá ser funcionario científico e investigador perteneciente a las Escalas del Consejo Superior de Investigaciones Científicas, de acuerdo con la disposición adicional vigésima sexta.» 
blicas seleccionan su personal, ya sea funcionario, ya laboral, de acuerdo con su oferta de empleo público mediante convocatoria pública y a través del sistema de concurso, oposición o concurso-oposición libre en los que se garanticen en todo caso los principios constitucionales de igualdad, mérito y capacidad así como el de publicidad ${ }^{91}$.

Hemos expuesto hasta ahora la situación actual. No obstante, la regulación relativa a la habilitación del profesorado y a la publicación de datos de evaluación de su actividad van sufrir una sustancial modificación. Así, el Proyecto de Ley Orgánica por la que se modifica la Ley Orgánica 6/2001, de 21 de diciembre cambia el acceso a los cuerpos funcionarios docentes, suprimiendo la habilitación nacional y sustituyéndola por una acreditación nacional y un concurso para el acceso a plazas de los Cuerpos Docentes Universitarios. La vigencia del principio de publicidad en relación con los solicitantes y concursantes dependería, inicialmente, de que se establezca como un procedimiento selectivo o de concurrencia competitiva, y que, por tanto, existan un número limitado de acreditados o de personas que acceden a plazas a cuerpos docentes universitarios. El art. 57 del Proyecto regula la acreditación nacional en el que se prevé que el acceso a los cuerpos de funcionarios docentes universitarios exigirá "la previa obtención de una acreditación nacional que, valorando los méritos y competencias de los aspirantes, garantice la calidad en la selección del profesorado funcionario. El Gobierno, previo informe del Consejo de Universidades, regulará el procedimiento de acreditación que, en todo caso, estará regido por los principios de publicidad, mérito y capacidad, en orden a garantizar una selección eficaz, eficiente, transparente y objetiva del profesorado funcionario, de acuerdo con los estándares internacionales evaluadores de la calidad docente e investigadora. La acreditación será llevada a cabo mediante el examen y juicio sobre la documentación presentada por los solicitantes, por comisiones compuestas por profesores de reconocido prestigio docente e investigador pertenecientes a los cuerpos de funcionarios docentes universitarios. Igualmente podrán formar parte de estas comisiones expertos de recono-

91 El Real Decreto 364/1995, de 10 marzo, que desarrolla el Reglamento de Ingreso del Personal al Servicio de la Administración General de Estado y de Provisión de puestos de trabajo y Promoción Profesional de los Funcionarios Civiles de la Administración General del Estado, establece en su artículo 22.1 los criterios de publicidad de los resultados de las pruebas de ingreso, estableciendo en el artículo 47 la publicidad de la resolución de los procedimientos de promoción interna. En estos casos, se establece la necesaria publicidad de dichos resultados a través de su publicación en el Boletín Oficial del Estado. 
cido prestigio internacional o pertenecientes a centros públicos de investigación".

No parece que el procedimiento de acreditación vaya a ser selectivo o de concurrencia competitiva, al no existir un número limitado de acreditaciones. De hecho la selección no es efectuada por la Comisión de Acreditación sino por las Comisiones de las Universidades que resolverán el acceso a plazas de cuerpos docentes universitarios. La obtención de una acreditación nacional va encaminada a garantizar una selección eficaz y objetiva del profesorado universitario, pero no es la selección en sí misma, que se lleva a efecto en un momento posterior. No obstante, el hecho de que la acreditación no sea un procedimiento selectivo o de concurrencia competitiva y que, por tanto, la publicidad no sea una exigencia de la Ley 30/1992, no impide que el legislador pueda prever, como ha hecho, la vigencia de este principio, además del de mérito o capacidad, lo que obvia este debate. El legislador puede exigir la publicidad expresamente en el procedimiento de acreditación como garantía de una mayor transparencia, teniendo en cuenta que es el paso previo necesario para convertirse en funcionario docente. El acceso a plazas de los Cuerpos Docentes Universitarios - regulado en el art. 62 del Proyecto- sí que es claramente un procedimiento selectivo. Se trata de un concurso, procedimiento selectivo por antonomasia, que resuelve el acceso a unas plazas limitadas dotadas en el presupuesto, desarrollado por unas comisiones de selección reguladas en los estatutos de cada universidad. De hecho, las comisiones que juzgan los concursos de acceso no pueden proponer una relación de candidatos que exceda del número de plazas - art. 65-. Se trata, por tanto, de una adjudicación de plazas que supone la incorporación a la función pública lo que exige, como ya hemos señalado anteriormente, la vigencia plena del principio de publicidad.

La vigencia del principio de publicidad es una medida más en la búsqueda de un procedimiento de selección del profesorado universitario que valore adecuadamente el mérito y la competencia de los aspirantes de forma que se facilite la calidad y la objetividad en la selección, de acuerdo con estándares internacionales. La publicidad se transforma en un instrumento que vela por la vigencia del principio de mérito y capacidad. Se establece así una garantía de procedimiento -la publicidad- que favorezca la vigencia de un derecho sustantivo, el derecho fundamental al acceso a la función pública en condiciones de igualdad - art. 23.2 CE- y en virtud de los principios de mérito y capacidad ya que la publicidad permite un mayor control social sobre la correcta valoración de los aspirantes, dificultando y aireando las decisiones arbitrarias. No establece el Proyecto de Ley el alcance de la pu- 
blicidad en el procedimiento de acreditación y de acceso a la función pública. La regulación posterior que apruebe el Gobierno deberá precisar si deben publicarse los currículos de los solicitantes o una información más reducida.

El Proyecto de Ley Orgánica prevé que "[l]os currículos de los miembros de las comisiones de acreditación se harán públicos tras su nombramiento" - art. 57.2 - Esta medida iba encaminada también a favorecer, a través de la publicidad, el control del cumplimiento de que las Comisiones que lleven a efecto la acreditación estarán compuestas por profesores de reconocido prestigio docente e investigador de la que podrán formar parte expertos de reconocido prestigio internacional y cuya composición deberá ajustarse a los principios de igualdad, profesionalidad y composición equilibrada entre hombres y mujeres. Igualmente, el proyecto de Ley Orgánica -art. 62.3- establece también la misma publicidad para los componentes de las comisiones de cada universidad que van a resolver los concursos de acceso a plazas de los Cuerpos Docentes Universitarios: "[e]n cualquier caso, los currículos de los miembros de las comisiones deberán hacerse públicos». Esta publicidad es también un instrumento formal que garantice "la aptitud científica y docente de [los] componentes" de unas comisiones que deben ajustarse a los principios de «imparcialidad y profesionalidad de sus miembros" y que permitan valorar objetivamente el historial académico, docente e investigador del candidato, su proyecto docente e investigador, así como contrastar sus capacidades en una sesión que deberá ser pública. Si hasta ahora, a partir de los principios establecidos en la Ley 30/1992 debía ser pública la identidad de los miembros de las comisiones de acreditación y de las comisiones de acceso a las plazas, en virtud de este proyecto de Ley va a ser público también su currículo.

En esta dirección hay que señalar que el Grupo Parlamentario Socialista en el Senado ha presentado una enmienda al Proyecto de Ley para incluir una Disposición Adicional Vigésimo Primera - nueva- en la LOU que establece que «el Gobierno regulará, previo informe de la Agencia Española de Protección de Datos, el contenido de los currículos a los que se refieren los artículos 57.2 y 62.3». Esta disposición pretende que el Gobierno regule expresamente el contenido de los currículos de los miembros de las Comisiones de Acreditación, teniendo en cuenta que se van a hacer públicos. Por ello, establece un informe de la Agencia Española de Protección de Datos, que será preceptivo pero no vinculante. Es razonable que la Autoridad de Protección de Datos intervenga llevando a cabo un cierto control previo - prior checking-, en el que tendrá que valorar sobre todo la vigencia del principio de calidad 
tanto en el currículo que se presenta como el que se hace público. No tendría sentido, por ejemplo, que se diera publicidad a algunos datos identificativos que excedan del nombre y apellidos - domicilio, DNI, etc-. Es lógico que este informe lo lleve a cabo la Agencia Española y no las Agencias Autonómicas pues estamos hablando de un Real Decreto del Estado. No obstante, no hay que olvidar que las Universidades están sometidas al control por parte de las Autoridades Autonómicas de Protección de Datos.

La enmienda del Grupo Parlamentario Socialista en el Senado da un paso más ya que establece la publicidad no sólo del procedimiento de acreditación nacional y del de acceso a la función pública del profesorado sino también de la evaluación de actividad docente e investigadora llevada a cabo tanto por las Universidades como por las Agencias y otras instituciones públicas. Así, la enmienda - de adición- que propone una nueva Disposición Adicional Vigésimo Primera de la LOU señala que «[i]gualmente no será preciso el consentimiento del personal de las universidades para la publicación de los resultados de los procesos de evaluación de su actividad docente, investigadora y de gestión realizados por la Universidad o por las agencias o instituciones públicas de evaluación. El Gobierno regulará, previo informe de la Agencia Española de Protección de Datos, el contenido académico y científico de los currículos de los profesores e investigadores que las universidades y las agencias o instituciones públicas de evaluación académica y científica pueden hacer público, no siendo preciso en este caso el consentimiento previo de los profesores o investigadores". La Disposición quiere publicar datos personales de los profesores, en concreto los resultados de los procesos de evaluación de su actividad docente - las encuestas académicas, fundamentalmente-, investigadora - sexenios, acreditaciones-y de gestión realizada tanto por las propias Universidades como por la Administración del Estado y de las Comunidades Autónomas -las distintas Agencias e instituciones públicas de evaluación como la Agencia Nacional de Evaluación de la Calidad y Acreditación ${ }^{92}$ y los organismos equivalentes de las Comunidades Autónomas-. Es un precepto poco delimitado y que contiene, en cierta medida, una cláusula abierta que permite la publicación de una amplia información personal. Si bien la regulación -antes analizada- de la acreditación nacional y del acceso a la función pública docente hacía referencia básicamente al procedimiento de incorporación a cuerpos de funcionarios, esta previsión de la enmienda relativa a la evaluación de

92 La Agencia Nacional de Evaluación de la Calidad y Acreditación debe actuar conforme a los principios de independencia y transparencia - art. 32-. 
la actividad docente e investigadora alcanza también a aquellos profesores que no se incorporen a la función pública y a los docentes de las Universidades Privadas. No habla la enmienda de la publicación del currículo de los miembros de las Agencias y de las Comunidades Autónomas responsables de la evaluación, a los que debe aplicarse la misma publicidad prevista para los miembros de las comisiones de acreditación y de acceso a la función pública docente.

El legislador es consciente de que está regulando una cesión de datos personales a terceras personas sin consentimiento del interesado, lo que exige una habilitación legal —art. 11 LOPD—. No se podría establecer esta publicidad a través de un Real Decreto o de otra norma reglamentaria, lo que contrasta con la normativa de la Comunidad de Madrid que estableció la publicación de datos de profesores a través de una Orden de una Consejería sin acudir a la preceptiva Ley autonómica que así lo estableciera ${ }^{93}$. La enmienda no pretende que todos los datos de profesores sean públicos, por lo que se remite a una regulación del Gobierno que establezca cuál es el contenido académico y científico de los profesores e investigadores que va a ser publicado. La enmienda establece como garantía formal un informe preceptivo no vinculante de la Agencia Española de Protección de Datos de la normativa estatal que regule la publicación, sin perjuicio de las facultades de supervisión de las Agencias Autonómicas en las Administraciones y Universidades de su respectiva competencia.

Aunque la cesión de datos exija una habilitación legal, el Legislador no dispone de una absoluta libertad. La futura Ley Orgánica de Universidades debe respetar todos los derechos fundamentales, $y$, en este caso, el derecho fundamental a la protección de datos personales, que como todo derecho no es absoluto sino que debe estar sometido a límites. Es muy importante llevar a cabo un adecuado equilibro de derechos fundamentales. Por un lado, hay que respetar el derecho a la privacidad y a la protección de datos personales - art. $18 \mathrm{CE}$ - Por otro, hay que garantizar otros derechos como el derecho a la educación de los alumnos que requiere de una información para poder elegir -art. 27 CE—, la libertad académica - art. 27.10-, el derecho al acceso a la función pública y a la promoción en la misma en virtud del principio de mérito y capacidad -arts. 23.2 y $103.3 \mathrm{CE}$ - y los principios constitucionales que obligan a la Administración Pública a ser objetiva y al sometimiento pleno a la ley y al derecho —art. 103.1 CE_, prohibiendo

93 La Asamblea de Madrid sólo ha aprobado cuatro leyes distintas a la de Presupuestos y a la de Acompañamiento en la Legislatura 2003-2007. 
la arbitrariedad - art. 9.3 CE-. Estos derechos exigen, en muchas ocasiones, una mayor transparencia de la Administración. El motivo para aprobar esta Enmienda, a juicio del Grupo Socialista, es «[i]ncorporar las previsiones de la regulación general de protección de datos de carácter personal a la legislación universitaria adecuando su normativa a las necesidades y características del servicio universitario". Detrás de esta propuesta está la convicción de que la mejora de la Universidad Pública y de la Administración pasa por una mayor transparencia que ofrezca una mejor información al público y permita un control social. Por ello, el Gobierno está trabajando en un Anteproyecto de Ley sobre transparencia administrativa ${ }^{94}$. Su aplicación al ámbito universitario viene motivada por la opinión de que la mejora de las Universidades requiere una evaluación constante de la actividad docente e investigadora de su personal y esta evaluación debe ser transparente. La Disposición pretende facilitar una evaluación pública del profesorado, un colectivo que evalúa y que debe acostumbrarse también a ser evaluado. Además, se quiere ofrecer una mejor información que favorezca la elección del profesor y de la Universidad por parte de los alumnos y, de esta manera, valorar el esfuerzo individual docente e investigador, permitiendo su reconocimiento social y fomentando la competencia.

No vamos a repetir ahora nuestra posición en relación con el enjuiciamiento constitucional de las leyes, favorable a una mayor deferencia al legislador, específicamente cuando está orientada a dar preferencia a los valores procedimentales sobre los sustantivos ${ }^{95}$. No obstante, es indispensable la interpretación de esta Disposición teniendo en cuenta el principio de calidad y el principio de proporcionalidad, que forman parte del contenido esencial del derecho fundamental a la protección de datos. De manera específica, es necesario diferenciar, por una parte, entre una publicación que permita el acceso a esta información de los interesados y grupos sociales legitimados en el ejercicio de un control social de la Universidad y que son actores específicos en la transparencia

94 Sobre la cuestión ya me he pronunciado en la Jornada organizada por la Audiencia Nacional en el año 2006, manteniendo una visión flexible en relación con las cesiones de datos entre Administraciones Públicas $-\mathrm{y}$ crítica, por tanto, con la STC 292/2000, de 30 de noviembre- pero más rígida en relación con la publicación de datos personales abiertos en Internet porque supone una cesión indiscriminada a terceras personas.

95 Cfr. A. Troncoso Reigada, Interpretazione della Constituzione e judicial restraint. Bologna, 1993; “Método jurídico, interpretación constitucional y principio democrático», E. EsPín y J. DíEZ REVORIO (coord), La justicia constitucional en el Estado Democrático, Tirant lo blanch, Valencia, 2000, págs. 17-42. 
del procedimiento y una publicación libre y abierta en Internet, que permita el conocimiento de datos curriculares de los profesores por personas que no están interesados en la Universidad ni en su transparencia. No parece razonable que el currículo de un profesor sea conocido por los vecinos, por la familia política, por los deudores o acreedores o por el arrendador o arrendatario de la propia vivienda. Por tanto, no tendría sentido que esta información se ofreciera abiertamente en Internet y que sea accesible a través de los distintos buscadores. Además, es indispensable que esa información sea cancelada cuando haya dejado de ser necesaria.

\section{b) La publicación de los directorios telefónicos y de correo electrónico de los profesores}

Las Universidades disponen de un directorio de todo su personal con datos de teléfono y de correo electrónico. Tanto el teléfono como el correo electrónico son datos de carácter personal al ser una información concerniente a personas físicas identificadas o identificables. Por ello, los directorios de la Universidad deben respetar el ordenamiento jurídico de protección de datos personales.

En este sentido ha existido un debate acerca de si el teléfono o la dirección de correo electrónico del profesor es un dato reservado y cada uno es libre de facilitarlo o si, por el contrario, es un dato público. Es importante señalar que estamos hablando de teléfonos y de direcciones de correo electrónico que están en el dominio de la Universidad y que han sido facilitadas por la Universidad a los profesores y al personal para el cumplimiento de sus funciones públicas, con la finalidad de que cualquier alumno pueda entrar en comunicación con él. Desde una perspectiva, se puede considerar que los medios para el ejercicio de funciones públicas no son un ámbito de privacidad. Uno no tiene la misma privacidad cuando desarrolla funciones públicas que cuando se encuentra en su esfera privada. Es verdad que el despacho de un profesor está protegido por el derecho a la intimidad. Igualmente el contenido del correo electrónico o de la conversación telefónica están protegidos por el secreto de las comunicaciones ${ }^{96}$. Pero eso no impide

96 El Consejo de Gobierno de la Universidad de Valencia aprobó el 22 de octubre de 2002 unas Normas de uso personal de los recursos informáticos y telemáticos de dicha Universidad, donde se regula las direcciones de correo electrónico dadas a su personal. Cfr. http://www.uv.es/ sgeneral/val/normes/normes/NormesUsTIC_cas.html. Estas Normas han sido preparadas por Ricard Martínez, Coordinador Jurídico de 
que el teléfono y la dirección de correo electrónico puedan ser conocidas por los alumnos. Así, si el teléfono y el correo electrónico que una Universidad da a un profesor no son para el conocimiento de los alumnos y de la comunidad universitaria, para qué se los da. Hay que resaltar que este debate no se refiere al teléfono particular o a la dirección de correo electrónico personal del profesor y que se encontraría protegida por el derecho a la vida privada - art. $18 \mathrm{CE}$ -

Que el teléfono y la cuenta de correo electrónico del personal de la Universidad no sea un dato privado no quiere decir que no esté amparado por el derecho fundamental a la protección de datos personales. Este derecho fundamental, a diferencia del derecho a la intimidad, protege todo tipo de datos personales, sean o no íntimos. El teléfono y la cuenta de correo electrónico no es un ámbito de vida privada pero sí es un dato de carácter personal, referido a una persona física identificada o identificable. Por ello hay que respetar los principios y los derechos de protección de datos, entre los que hay que destacar especialmente el principio de calidad - por el cual estos datos sólo pueden ser empleados para una finalidad universitaria y no, por ejemplo, para una finalidad comercial o ajena a la universidad-, el principio de información y la comunicación de datos personales a terceros ${ }^{97}$. Estos directorios deben estar declarados como ficheros de datos personales ${ }^{98}$.

No obstante, el tratamiento de estos datos personales del profesor en el directorio de la Universidad no exigiría el consentimiento del afectado ya que se refiere a las partes de un contrato de una relación administrativa y laboral y son necesarias para el cumplimiento de ésta —art. 6.2 LOPD-. Además, en las Universidades públicas se une la ex-

Bases de Datos de la Universidad de Valencia, al que el autor de estas páginas quiere agradecer la ayuda en este campo. En ellas se señala que "[e]l correo electrónico es inviolable y nadie podrá acceder ni a los contenidos ni a las cabeceras, si no es con el consentimiento expreso y por escrito del usuario o mediante autorización judicial. El secreto de las comunicaciones llega también a la identidad y a los destinatarios de la información. El personal informático que por cualquier razón tenga que acceder a información técnica que permita identificar a los usuarios resulta especialmente vinculado por el deber de secreto y confidencialidad -art. 13-.

${ }^{97}$ Por ejemplo, el directorio de correo electrónico de profesores no podría ser utilizado para enviar mensajes masivos para dar publicidad al alquiler o a la búsqueda de un apartamento de verano, para vender un ordenador de segunda mano, etc.

${ }_{98}$ Hay que declarar el fichero de log, imprescindible para el mantenimiento del servicio de correo electrónico, en el que se hacen constar los datos de emisión y recepción del correo electrónico. En cambio, las redes de telecomunicaciones no suponen tratamientos de datos personales. 
cepción del consentimiento para el cumplimiento de funciones administrativas - art. 6.2 LOPD-. El profesor puede ejercer el derecho de oposición. Así, como señala el art. 6.4 LOPD, "[e]n los casos en los que no sea necesario el consentimiento del afectado para el tratamiento de los datos de carácter personal y siempre que una ley no disponga lo contrario, éste podrá oponerse a su tratamiento cuando existan motivos fundados y legítimos relativos a una concreta situación personal. En tal supuesto, el responsable del fichero excluirá del tratamiento los datos relativos al afectado". Así, una persona que haya recibido amenazas o incluso que haya recibido correos electrónicos con virus, podría ejercitar el derecho de oposición a estar en este directorio de correos electrónicos ${ }^{99}$.

La cuestión principal es determinar cuál debe ser el nivel de acceso a estos directorios telefónicos y de correo electrónico. Hay tres posibilidades: la más restrictiva sería entender que el teléfono y el correo electrónico debe ser conocido únicamente cuando existe una relación jurídica específica; así, cada alumno podría conocer únicamente el correo electrónico y el teléfono de los profesores de las asignaturas en las que está matriculado. La más amplia implicaría entender que la información del directorio de la Universidad debe ser accesible al público en general a través de Internet por la especial relación que mantiene la Universidad con la sociedad ${ }^{100}$. La posición intermedia significa considerar que el directorio debe ser conocido por todo el personal de la Universidad - debe estar en una intranet- porque su función es permitir la comunicación intrauniversitaria pero no debe acceder personal ajeno a la Universidad.

99 Así, las Normas de uso personal de los recursos informáticos y telemáticos de la Universidad de Valencia establecen que «[c]uando la protección de la vida privada del usuario, la recepción de mensajes que incluyan amenazas o expresiones inadecuadas y cualquier otro supuesto equivalente lo aconseje, se excluirá la dirección de las listas públicas y se podrá solicitar la sustitución de la cuenta de correo por otra nueva para proteger la identidad del usuario» —art. 11.3—.

100 Este es el criterio de la Universidad de Valencia que cuelga el directorio universitario en internet. El art. 10 de su normativa señala: "Pueden disfrutar del servicio de correo electrónico los miembros de la comunidad universitaria, tanto los estudiantes matriculados en cualquier ciclo como el personal de administración y servicios y el personal docente e investigador, además de las entidades o personas autorizadas en virtud del convenio o autorización debidamente emitida por el órgano competente de la Universidad de Valencia. El servicio se vincula a la existencia de vínculo con la Universidad de Valencia. EI SIUV establecerá el espacio de memoria en disco atribuido a las cuentas de correo". 
La legislación ha reconocido la importancia de la transparencia administrativa y del derecho de los ciudadanos a identificar a los funcionarios que presten servicios públicos. La Ley 30/1992, de 26 de noviembre, de Régimen Jurídico de las Administraciones Públicas y del Procedimiento Administrativo Común, establece en el párrafo quinto de su Exposición de Motivos la necesidad de "garantizar la calidad y transparencia de la actuación administrativa». El objetivo del legislador se ha traducido en la fijación de un principio general en el artículo 3.5 de esta Ley conforme al cual "en sus relaciones con los ciudadanos las Administraciones Públicas actúan de conformidad con los principios de transparencia y de participación". Asimismo, el artículo 35 atribuye a los ciudadanos, en sus relaciones con las Administraciones Públicas dos derechos relacionados con este principio: «b) A identificar a las autoridades y al personal al servicio de las Administraciones Públicas bajo cuya responsabilidad se tramiten los procedimientos; g) A obtener información y orientación acerca de los requisitos jurídicos o técnicos que las disposiciones vigentes impongan a los proyectos, actuaciones o solicitudes que se propongan realizar».

La posición más restrictiva para el acceso al directorio se puede argumentar en virtud de que la relación jurídica administrativa que justifica la ausencia de consentimiento para el tratamiento se establece entre personas concretas de la comunidad universitaria. La posición más amplia puede justificar la publicación en Internet, es decir, la cesión de datos a terceros, a partir de la habilitación legal mencionada en la Ley 30/1992, que plantea un deber de información general que no se hace depender de la invocación de un interés legítimo o vinculado a un procedimiento concreto, a diferencia de lo previsto por el artículo 105 b) de la Constitución y de su desarrollo por el artículo 37 de la Ley 30/1992. Ello justificaría, por tanto, la puesta a disposición del público en Internet de la relación de identidades, cargo, dirección y teléfono del personal de la Universidad. La existencia de una previsión legal específica eludiría la obtención del consentimiento de cada funcionario para la publicación de sus datos profesionales ${ }^{101}$.

Existe un debate acerca de si el directorio telefónico y de correo electrónico es una fuente accesible al público, lo que permitiría su

101 Para Ricard Martinez, la cesión de datos del citado fichero «Base de datos de telefonía" podría deducirse de los artículos 11.2.a) en relación con el 3 f) de la Ley Orgánica 15/1999 así como de los principios derivados de los artículos 3.5 y 35 . b) y g) de la Ley 30/1992. 
consulta por cualquier persona ${ }^{102}$. El art. 3.j) LOPD establece un elenco tasado de fuentes accesibles al público: censo promocional, los repertorios telefónicos, los diarios y boletines oficiales, los medios de comunicación y "las listas de personas pertenecientes a grupos de profesionales que contengan únicamente los datos de nombre, título, profesión, actividad, grado académico, dirección e indicación de su pertenencia al grupo». En los directorios universitarios se indica únicamente el nombre y apellidos, el puesto de trabajo, el teléfono y la dirección de correo electrónico. Así, se ha afirmado que el personal de la Universidad tanto laboral como funcionario en cualquiera de sus cuerpos y escalas constituye un grupo profesional, en ausencia de una mayor definición en la legislación sobre colegios profesionales y en la de función pública. El Dictamen 1/2000, de 3 de febrero, del Grupo de Trabajo sobre Protección de Datos del artículo 29, sobre "determinados aspectos de protección de datos del comercio electrónico" mantiene que se puede utilizar las listas de correo electrónico que aparezcan en directorios públicos, siempre que se respete el principio de finalidad -art. 4 LOPD - ${ }^{103}$. La Directiva señala que los datos personales deben ser recogidos con fines determinados, explícitos y legítimos y tratados de manera leal y lícita compatible con dichos fines - art. 6 de la Directiva 95/46/CE- ${ }^{104}$. En esta dirección, las normas de la Universidad de Valencia de uso personal de los recursos informáticos y telemáticos determinan que la finalidad de las direcciones de correo electrónico concedidas por la Universidad es la ges-

102 Así, Ricard Martínez entiende que el fichero "Base de datos de telefonía", con datos de identidad, cargo, dirección y teléfono, recogido en el Anexo VIII de la Resolución de 15 de julio de 2003, del Rectorado de la Universidad de Valencia, debe tener la consideración de fuente accesible al público.

103 Este Dictamen se puede ver en la Memoria de la Agencia Española de Protección de Datos 2000, págs. 688-691.

104 Así, señala el Dictamen que si una dirección de correo electrónico se obtiene en un espacio público de internet, su utilización para envíos comerciales electrónicos sería contraria a la legislación comunitaria correspondiente, por ser un tratamiento desleal de los datos personales, ya que es contraria al principio de finalidad puesto que el interesado proporcionó su dirección de correo electrónico para una finalidad muy distinta, y dado el desequilibrio de coste y la interrupción del destinatario, por considerar que estos envíos no superarían la prueba del equilibrio de intereses establecida en el art. 7.f de la Directiva. Esta establece que una de las posibles bases legítimas para el tratamiento exige que éste sea "necesario para satisfacer un interés legítimo perseguido por el responsable del tratamiento siempre que no prevalezca el interés o los derechos y libertades fundamentales del interesado".

(C) UNED. Revista de Derecho Político 
tión académica, la docencia y la investigación ${ }^{105}$. Las direcciones de correo electrónico referidas "pueden ser difundidas con la indicación clara de las finalidades de estas direcciones y la advertencia expresa de que no serán utilizadas para la remisión de mensajes con otras finalidades ${ }^{106}$. Así, por ejemplo, la utilización de la lista de distribución por las centrales sindicales para difundir información sindical representa un uso legítimo del fichero ${ }^{107}$. En cambio, una utilización del listado de distribución para finalidades distintas a las académicas o su cesión a terceras personas supondría una infracción grave a la legislación de protección de datos personales ${ }^{108}$.

A nuestro parecer es más razonable la posición intermedia, es decir, la publicación del directorio telefónico y de correo electrónico de profesores en la intranet o red local de la Universidad. Esto permite el acceso a todo el personal de la Universidad pues entre todo él es posible una comunicación intrauniversitaria que sea respetuosa con el principio de calidad y con la finalidad del fichero. La necesidad de información personal sobre los profesores y la relación administrativa no se circunscribe a las asignaturas matriculadas sino que puede alcanzar a otras personas de la comunidad universitaria. La publicación del directorio en la

105 «Las cuentas de correo electrónico asignadas al personal de administración y servicios y al personal docente e investigador se proporcionan esencialmente para la satisfacción de las finalidades de gestión académica, docencia e investigación de la Universidad de Valencia» - art. 11.1-.

106 De hecho, en el sitio web de la Universidad de Valencia se publica un listado de usuarios de correo. En ella se contiene la leyenda siguiente: "Las direcciones de correo electrónico de la Universidad de Valencia son objeto de publicación en esta lista para finalidadades exclusivamente académicas y administrativas. Su empleo para cualquier uso distinto de los aquí señalados, y en particular para fines comerciales o envíos masivos de correo basura - "spam»- se considerará contrario a los principios del art. 4 de la Ley Orgánica 15/1999, de 13 de diciembre, de Protección de Datos de Carácter Personal y a sus equivalentes en la Directiva 95/46/CE y será puesto en conocimiento de las autoridades competentes en materia de protección de datos" Cfr. http://uv.es/uvalen/cas/directorio/html

107 No obstante, esta información sindical también puede ser enviada a través del propio administrador de la lista, que adjuntaría la información sindical, sin necesidad de tener que publicar el directorio en internet. Cfr. más ampliamente A. TRONCOSO REIGADA, "Libertad sindical, libertad de empresa y autodeterminación informativa de los trabajadores", en A. FARRIOLS, La protección de datos de carácter personal en los centros de trabajo, Ed. Cinca-Fundación Largo Caballero-CLI, Madrid, 2006, págs. 103-138

108 Así, la Agencia Española de Protección de Datos consideró que la cesión de 30.000 direcciones de correo electrónico desde la Universidad Politécnica de Valencia hacia una empresa era una infracción a la LOPD. Cfr Memoria de la Agencia Española de Protección de Datos 1999. 
intranet se convierte así en un instrumento de comunicación en la Universidad y de fortalecimiento de las relaciones académicas. Por ello, esta publicación de los datos de nombre, puesto, teléfono y correo electrónico del personal de la Universidad a través de una intranet no requeriría el consentimiento del interesado ya que, como hemos señalado antes, el tratamiento se refiere a las partes de un contrato de una relación administrativa y laboral y es necesario para el cumplimiento de ésta -art. 6.2 LOPD_. En el caso de que se entendiera que la publicación del directorio en intranet es una cesión de datos - que no sería nuestra posición- también estaría excepcionado el consentimiento ya que el tratamiento responde a la libre y legítima aceptación de una relación jurídica cuyo desarrollo implica la conexión con ficheros de terceros -art. 11.2.c) LOPD-. En ese caso la comunicación sólo será legítima cuando se limite a la finalidad que la justifique.

En cambio, la publicación del directorio libremente en Internet y accesible al público en general representa una cesión indiscriminada a terceros sin que exista detrás una función administrativa clara que justifique el acceso a información personal. Esta publicación libre en Internet facilita, además, su utilización indebida para el envío de spam y de correos no deseados. La necesidad de comunicarse con la Universidad desde fuera de la comunidad universitaria puede satisfacerse mediante la publicación en Internet de las direcciones institucionales -correos electrónicos y teléfonos de los distintos departamentos, vicedecanatos, decanatos, etc-. Por último, las listas de personas pertenecientes a grupos profesionales a las que se refiere la LOPD son las de los Colegios Profesionales, a tenor del art. 28.2 LOPD, cuya publicación es necesaria para desarrollar su actividad de ordenación profesional. Es verdad que el nombramiento de los funcionarios universitarios ha sido publicado en un diario oficial, lo que convierte este dato en una fuente accesible al público. No obstante, la mayoría de los datos personales que aparecen en los directorios no han sido publicados en diarios oficiales y no tienen ese carácter. Además, el hecho de que los boletines oficiales tengan el carácter de fuente accesible al público no suprime lo establecido en el art. 21.3 LOPD en relación con el art. 11.2.b) que indica claramente que la comunicación de datos recogidos de fuentes accesibles al público no podrá efectuarse a ficheros de titularidad privada, sino con el consentimiento del interesado o cuando una Ley prevea otra cosa.

Vamos a analizar seguidamente la publicación de datos de alumnos. Uno de los supuestos a debate es la posibilidad de publicar en la intranet el nombre y la dirección de correo electrónico que la Universidad ha dado a los alumnos. La Agencia Española de Protección de Datos ha afirmado que la publicación de estos datos con carácter restringido al 
resto de los alumnos y personal de la universidad requiere el consentimiento del interesado ${ }^{109}$. No obstante, también se puede mantener que no es preciso este consentimiento ya que se refiere a las partes de una relación negocial y estos datos personales son necesarios para su mantenimiento y cumplimiento, en este caso, para el desenvolvimiento de las relaciones académicas y de gestión universitaria.

\section{LA PUBLICACIÓN Y CESIÓN DE DATOS DE ALUMNOS}

\section{a) La publicación de calificaciones de alumnos en tablones de anuncios $y$ sitios web}

Un supuesto que merece un estudio especial es la publicación de listados y calificaciones de los alumnos en tablones de anuncios y en sitios web. Como hemos señalado anteriormente, es imprescindible distinguir situaciones donde rige el principio de publicidad, de ámbitos donde no rige este principio, al no existir un procedimiento selectivo o de concurrencia competitiva - art. 59.5 b) de la Ley 30/1992-. Así, rige el principio de publicidad en el procedimiento de admisión de alumnos en las Universidades al ser éste un procedimiento selectivo, por lo que debe publicarse el listado de alumnos con los datos personales identificativos. Esta publicación es garantía de transparencia y permite la notificación al interesado ${ }^{110}$. En todo caso, el principio de calidad de los datos exige publicar en el listado de alumnos admitidos únicamente aquellos datos necesarios para la identificación y admisión, evitando así el tratamiento de datos excesivos. Igualmente debe producirse la publicación del listado de las personas y de las calificaciones en los Premios Extraordinarios de Licenciatura o de Doctorado o en la adjudicación de becas, al ser éstos procedimientos selectivos donde rige el principio de publicidad.

Un caso distinto son las calificaciones académicas de cada asignatura que tienen como destinatarios a los alumnos y que deben anotarse en su expediente académico. La calificación de los alumnos no es un procedimiento de concurrencia competitiva ${ }^{111}$. Por tanto, no hay una

109 Informe de 8 de octubre de 2003.

110 Cfr. el Real Decreto 69/2000, de 21 de enero, por el que se regulan los procedimientos de selección para el ingreso en los centros universitarios de los estudiantes que reúnan los requisitos legales necesarios para el acceso a la universidad.

111 No hay en la Universidad un número limitado de aprobados, de notables o de sobresalientes. La concurrencia competitiva se daría únicamente en el caso de las 
habilitación legal clara que prevea la publicidad de manera general y que permita una cesión de datos sin consentimiento. Estas calificaciones académicas, aunque se enmarcan en procedimientos administrativos, no se rigen por el principio de publicidad sino sólo por la obligación de comunicación al interesado de la resolución de ese acto administrativo. La difusión de estas calificaciones a través de tablones de anuncios representaría teóricamente un supuesto de cesión de datos a terceros ${ }^{112}$. Por ello, sería necesario -a juicio de la Agencia Española de Protección de Datos-, debido a la inexistencia de una habilitación legal específica, que el alumno diera su consentimiento ya que la función administrativa que exceptúa el consentimiento da cobertura únicamente al tratamiento de sus datos personales por el profesor pero no a la cesión indiscriminada a terceros a través de la publicación ${ }^{113}$. La petición del consenti-

matrículas de honor, que son limitadas y que justificaría, en su caso, no la publicación de todas las calificaciones sino únicamente la de aquellos que obtienen sobresaliente y que pueden estar en disposición de concurrir a ellas.

112 Existe también una razón de coherencia. Si se niega el acceso de los padres a las calificaciones de sus hijos mayores de edad, no tendría sentido que las conocieran paseando por la Universidad.

113 Esta cuestión ha sido objeto de análisis por parte de la Agencia Española de Protección de Datos en su informe 469/2002 sobre «Publicación en tablones de las calificaciones de alumnos universitarios" disponible en la página web www.agpd.es, cuyos criterios fueron reiterados en los Informes de 11 de marzo de 2005 y de 14 de septiembre de 2005. La Agencia Española responde a la consulta de "si resulta conforme con lo establecido en la Ley Orgánica 15/1999, de 13 de diciembre, de Protección de Datos de Carácter Personal, la publicación de las calificaciones de los alumnos en los tablones anuncios de la Universidad consultante. A su vez, se plantea si dicha publicación puede referirse al número de Documento Nacional de Identidad o al Número de Expediente Personal de los alumnos y si, en cualquier caso, requiere el consentimiento del afectado". La Agencia Española afirma: "Con carácter general, puede señalarse que la publicación de los datos a los que se refiere la consulta (tanto relativos al nombre y apellidos de los alumnos, como a su número de Documento Nacional de Identidad o su Número de Expediente Personal), constituye una auténtica cesión de datos de carácter personal, definida por el artículo 3 i) de la Ley Orgánica 15/1999, como «toda revelación de datos realizada a una persona distinta del interesado." En relación con las cesiones, el artículo 11.1 de la propia Ley establece como regla general que «los datos de carácter personal objeto del tratamiento sólo podrán ser comunicados a un tercero para el cumplimiento de fines directamente relacionados con las funciones legítimas del cedente y del cesionario con el previo consentimiento del interesado". Entre las excepciones a la necesidad de ese consentimiento recogidas en el artículo 11.2 se encuentra el que la cesión se encuentre autorizada por una Ley. En este sentido, la obligación de notificar a los interesados las resoluciones administrativas que afecten a sus derechos e intereses se establece en el artículo 58 de la Ley 30/1992, de 26 de noviembre, de Régimen Jurídico de las Administraciones Públicas y del Procedimiento Administrativo Común. 
miento a los alumnos plantea el problema de qué hacer con aquellos que no otorgan ese consentimiento. En la actualidad, algunas Universidades han incluido dentro de los procesos de matriculación de alumnos unas cláusulas informativas donde se afirma que "el estudiante consiente en que la Universidad conforme a sus Estatutos puede publicar las calificaciones de las asignaturas". No obstante, no nos parece adecuado que la cláusula informativa que se incluye en la solicitud de matrícula in-

En dicho precepto y en el artículo siguiente se regulan taxativamente los supuestos en que tal notificación se producirá de forma distinta a la notificación personal, mediante la publicación del acto en tablones de edictos o de anuncios. Concretamente en el artículo 59.6.b) de la Ley 30/1992, de 26 de noviembre, se establece que la publicación sustituirá a la notificación cuando se trate de actos integrantes de un proceso selectivo. En consecuencia, a la posibilidad de publicar los listados de aspirantes con los resultados de un proceso selectivo, resultará de aplicación lo dispuesto por los citados artículos 58 y 59 de la Ley 30/1992, de 26 de noviembre, de Régimen Jurídico de las Administraciones Públicas y del Procedimiento Administrativo Común, resultando posible la publicación de los datos de carácter personal, siempre y cuando la convocatoria determine expresamente el lugar de publicación, y rigiendo sobre dichos supuestos el principio de publicidad derivado de la aplicación de lo dispuesto en los mencionados preceptos. Sin embargo, el supuesto sometido a consulta, esto es, la publicación de las calificaciones de los alumnos en los tablones de anuncios de la Universidad consultante, no queda amparado por lo establecido en los citados preceptos, por cuanto en dicho supuesto no nos encontramos en presencia de un proceso selectivo, sino ante una forma de comunicación y/o traslado de las notas de calificación correspondientes a cada asignatura, que tienen como destinatario únicamente a los alumnos afectados, anotándose -a su vez- en su expediente académico. En consecuencia la difusión de dichas notas de calificación a través de los tablones de anuncios de la Universidad, constituirá una cesión de datos de carácter personal de los alumnos no autorizada por una norma con rango de ley formal. En ese caso, atendiendo a la regulación de la Ley Orgánica (artículo 11.2. a), sería necesario que cada alumno diera su consentimiento inequívoco para poder realizar la publicación de las calificaciones, dado que estos supuestos no constituyen ninguna de las excepciones legales para poder efectuar las cesiones sin consentimiento. En este sentido, a través de los trabajos desarrollados en el marco del Protocolo de Colaboración suscrito el pasado 9 de junio de 2003 entre la Agencia Española de Protección de Datos y la Conferencia de Rectores de las Universidades Españolas (CRUE), siempre que se pretenda la publicación de las calificaciones de los alumnos en los tablones de anuncios de las Universidades, ésta Agencia ha propuesto la inclusión de la correspondiente cláusula de consentimiento inequívoco de los afectados en cumplimiento de lo dispuesto por el transcrito artículo 11.2.a) de la Ley Orgánica. Por lo demás, no siendo conforme con lo dispuesto por la Ley Orgánica 15/1999 la referida publicación, no es menester analizar la procedencia de la inclusión de determinado tipo de datos (D.N.I, Número de Expediente Personal de los alumnos, o cualquier otro) a los que se refiere el consultante en su escrito, cuando el consentimiento del afectado no ha sido convenientemente recabado. Es cuanto tiene el honor de informar a V.I» (la cursiva es nuestra). 
forme y fuerce - al mismo tiempo- a los estudiantes a aceptar la publicación - sin una limitación específica- de las calificaciones de las asignaturas. Además de que no se debe mezclar el principio de información con el consentimiento del interesado, este procedimiento no permite un consentimiento libre ya que la negativa del alumno impide la matriculación. Si se quiere realmente respetar el consentimiento del interesado para la publicación de las notas, éste debe separarse y no impedir el trámite de la matriculación Si se entiende que éste es un ámbito donde no debe existir el consentimiento del interesado, no debe fingirse que el alumno lo da cuando se matricula.

Lo que habría que hacer sería fortalecer los criterios que justifican la excepción del consentimiento. Por una parte, se puede instar la aprobación de un precepto legal que suponga una habilitación clara para la publicación de las calificaciones. La Agencia Española de Protección de Datos ha exigido una habilitación legal para permitir la publicación de las calificaciones en tablones de anuncios. Por ello, el Grupo Parlamentario Socialista ha presentado una enmienda - ya citada - al Proyecto de Ley Orgánica por la que se modifica la Ley Orgánica 6/2001, de 21 de diciembre, de Universidades, para añadir una Disposición adicional vigésimo primera que en su apartado tercero afirma: "No será preciso el consentimiento de los estudiantes para la publicación de los resultados de las pruebas relacionadas con la evaluación de sus conocimientos y competencias ni de los actos que resulten necesarios para la adecuada realización y seguimiento de dicha evaluación». Esta Enmienda, que daría cobertura legal a la publicación de calificaciones provisionales y definitivas, todavía no ha sido debatida ni aprobada. En todo caso, esta publicación debe limitarse al ámbito universitario y no debe ser accesible por personas no interesadas en el procedimiento administrativo - por ejemplo, no debe hacerse de manera abierta en Internet-. Por otra parte, se puede defender la existencia de una relación jurídica del alumno con la Universidad lo que implica la aceptación de la forma de publicación de notas incluidas en sus Estatutos - art. 116 c) de los Estatutos de la Universidad Carlos III de Madrid y art. 19.3 del Estatuto del Estudiante de la Universidad Complutense-. En ambos casos, sería bueno informar al alumno de la publicación de las notas en la solicitud de matriculación, no para solicitarle el consentimiento - hemos dicho que es un supuesto de excepción del mismo- sino para garantizar la información sobre los tratamientos y sobre los posibles destinatarios o cesionarios de la información - art. 5.a) LOPD-.

Hay que reconocer que es práctica habitual la publicación de las calificaciones en tablones de anuncios sin consentimiento de los intere- 
sados $^{114}$. En todo caso, también hay que valorar la posibilidad de que la publicación de las calificaciones de alumnos en tablones no infrinja el derecho fundamental a la protección de datos. Hay que llevar a cabo aquí también un delicado equilibrio de intereses entre el derecho fundamental a la protección de datos personales, por una parte, y, por otra, otros bienes constitucionales. Así, hay que valorar el principio de transparencia administrativa que puede aconsejar que aquellos que tengan un interés legítimo - que han concurrido a ese examen- puedan acceder a las calificaciones del grupo. Además, el derecho a la educación tiene en su contenido el derecho a una valoración de los alumnos que responda al principio de mérito y capacidad, lo que puede justificar el conocimiento de las calificaciones de otros. La existencia de una relación jurídica del alumno con la Universidad así como los propios estatutos de universidades pueden justificar la aceptación de una forma determinada de publicación de notas en tablones de anuncios. Además, la Ley 30/1992 atribuye al órgano competente en supuestos que no son de concurrencia competitiva el establecimiento de la forma de notificación al interesado y la apreciación de la necesidad de la publicidad ${ }^{115}$. Todo ello puede permitir la publicación de las calificaciones en tablones de anuncios en recintos universitarios con acceso restringido para profesores y alumnos — no para terceras personas- ${ }^{116}$.

La extensión de las tecnologías de la información en la sociedad y en la propia Universidad ha aconsejado utilizar intenet para facilitar información a los alumnos. Así, es legítimo publicar en internet las cali-

114 Ante esta circunstancia habría que recomendar como mejor práctica otros procedimientos como la publicación de los listados en los tablones de manera disociada, con referencia no al nombre y apellidos de los alumnos sino a su número de matrícula o a su número de expediente. De esta forma, la ordenación de los listados no tendría que ser alfabética sino por el número de expediente o de matrícula del alumno. No sería complejo que los servicios de informática de cada universidad elaboraran con destino a los profesores modelos de actas con nombres y apellidos pero con un fichero asociado para su publicación en papel con una referencia al número expediente académico. Sin embargo, E. FERNÁNDEZ —op. cit.considera que la publicación de listados con referencia a datos alternativos —número de expediente, número de matrícula- puede llegar a ser contraproducente porque va en detrimento de la facilitad de acceso a la información que tenían los lumnos hasta ese momento ya que pocos alumnos recuerdan estos datos. Además, este autor resalta los numerosos errores que pueden producirse en la escritura y lectura de los mismos ya que un número equivocado pasa a referirse a un alumno distinto.

115 En todo caso, los arts. 58 y 59 de la LRJAP y PAC limitan mucho los supuestos de notificación mediante la publicación de las resoluciones.

116 Este es el planteamiento que ha hecho la Universidad Carlos III de Madrid. 
ficaciones de las pruebas de acceso a la Universidad o la resolución de los Premios Extraordinarios, al ser estos procedimientos de concurrencia competitiva que se rigen por criterios de publicidad. Este avance en la sociedad de la información ha llevado a muchos profesores a publicar las calificaciones de los alumnos de manera abierta a través de internet. Este modelo de publicación supone una cesión indiscriminada a terceros. Esta publicación abierta en Internet representa una vulneración grave del derecho fundamental a la protección de datos de los alumnos. No obstante, se pueden habilitar procedimientos que permitan la utilización de Internet para facilitar la notificación de las calificaciones, al mismo tiempo que se garantiza el derecho a la confidencialidad de los alumnos. Así, se podría habilitar el acceso del alumno únicamente a su calificación, a través de la introducción de una clave. Esta no debe limitarse al número del Documento Nacional de Identidad ya que éste es un dato relativamente accesible ${ }^{117}$. Por ello, sería conveniente pedir algún otro dato, que conste, por ejemplo, en el impreso de solicitud de matriculación, como ocurre en la información solicitada a la Agencia Estatal de Administración Tributaria ${ }^{118}$ acerca de los datos fiscales para la elaboración del Impuesto de la Renta de las Personas Físicas ${ }^{119}$.

A este respecto quiero señalar que la Agencia de Protección de Datos de la Comunidad de Madrid ha declarado recientemente una in-

117 El Real Decreto 994/1999, de 11 de junio, por el que se aprueba el Reglamento de Medidas de Seguridad de los Ficheros Automatizados que contengan Datos de Carácter Personal señala en relación con las medidas de seguridad de identificación y autenticación que "[c]uando el mecanismo de autenticación se base en la existencia de contraseñas, existirá un procedimiento de asignación, distribución y almacenamiento que garantice su confidencialidad e integridad".

118 La Agencia Estatal de Administración Tributaria exige la introducción del DNI así como de la cifra de una casilla de la última declaración.

119 La publicación de las calificaciones en Internet con garantía de confidencialidad es el criterio que está introduciendo la Universidad Rey Juan Carlos. Hay que señalar la «Mención Especial de la Il Edición del Premio Europeo de Mejores Prácticas de Protección de Datos entre Administraciones Públicas Europeas» concedida a la Universidad Rey Juan Carlos de Madrid por este proyecto. Se trata de una automatización del proceso de manera que el profesor a través de una página web ofrezca la nota individual a cada alumno con una clave. Este sistema debe ser desarrollado de manera institucionalizada, debe ser único para todos los profesores, los ficheros deben estar declarados y la seguridad debe estar en manos de los servicios competentes de la Universidad. El problema está en que el profesor no publica un listado de notas para un examen sino que publica notas provisionales, notas definitivas, el acta definitiva, etc. La Universidad Rey Juan Carlos no quiere obligar pero sí animar al profesorado a seguir este modelo. 
fracción a la Universidad Complutense en este ámbito. La infracción no fue por publicar notas en tablones de anuncios - tendrían que declararse miles de infracciones por ello-. La infracción se produjo por la lectura por parte de profesores de calificaciones de alumnos en público convocando a los medios de comunicación -radio, prensa, televisión-para protestar porque la Consejería de Educación no pagaba el complemento retributivo a los profesores. La infracción era por incumplimiento del deber de secreto - lectura convocando a medios de comunicación-y utilización de datos para finalidades distintas - la publicación y lectura no tenía como finalidad la notificación al interesado sino que se había convertido en un instrumento de presión salarial ${ }^{120}$.

b) El derecho a la confidencialidad de los datos personales de los alumnos y el derecho de acceso de los padres al expediente académico de sus hijos. El pago de tasas en la certificación de los expedientes académicos

El derecho de acceso a los datos personales es un derecho personalísimo. Así, el art. 11 del Real Decreto 1332/1994, de 20 de junio, por el que se desarrollan determinados aspectos de la Ley Orgánica 5/1992, de 29 de octubre, de regulación del tratamiento automatizado de los datos de carácter personal señala que "[l]os derechos de acceso a los ficheros automatizados, así como los de rectificación y cancelación de datos son personalísimos y serán ejercidos por el afectado frente al responsable del fichero. [...] Podrá, no obstante, actuar el representante legal del afectado cuando éste se encuentre en situación de incapacidad o minoría de edad que le imposibilite el ejercicio personal de los mismos". De hecho, el derecho de acceso "se ejercitará mediante petición o solicitud dirigida al responsable del fichero, formulada por cualquier medio que garantice la identificación del afectado" ${ }^{121}$.

120 La Resolución de infracción fue confirmada por la Sentencia 1404/2006, de siete de diciembre, de la Sala de lo Contencioso Administrativo - sección octava- del Tribunal Superior de Justicia de Madrid.

121 En estos mismos términos se manifiesta la Instrucción 1/1998, de 19 de enero, de la Agencia de Protección de Datos, relativa al ejercicio de los derechos de acceso, rectificación y cancelación, donde se indica que "[l]os derechos de acceso a los ficheros automatizados, así como los de rectificación y cancelación de datos son personalísimos y serán ejercidos por el afectado frente al responsable del fichero por lo que será necesario que el afectado acredite su identidad frente a dicho responsable» -Norma primera-. 
Por tanto, el acceso a los datos personales de los expedientes académicos en el caso de hijos mayores de edad debe darse únicamente al titular de los datos. El hecho de que el derecho de acceso sea un derecho personalísimo dificulta el acceso de cualquier otra persona, si el titular de los datos no se encuentra en situación de incapacidad. Se puede afirmar que los padres no tienen derecho de acceso a los expedientes académicos de los hijos mayores de edad sin su consentimiento ${ }^{122}$.

En el supuesto de que se produzca un acceso indebido a los expedientes de los hijos por parte de los padres, estaríamos en presencia de una cesión de datos personales - art. 11 LOPD - sin consentimiento del interesado, lo que constituiría una infracción a la legislación de protección de datos personales, que puede ser denunciada ante las autoridades de control. Además, el hijo tendría la posibilidad de iniciar un procedimiento ante la jurisdicción penal por un delito de revelación de secretos - art. 197 del Código Penal—o de presentar una demanda de protección del derecho a la intimidad, en virtud de la Ley $1 / 1982$, de 5 de mayo, de protección civil del derecho al honor, a la intimidad personal y familiar y a la propia imagen.

Esta problemática no ocurre inicialmente con los hijos menores de edad ya que, en un principio, se puede afirmar que el derecho de acceso a sus datos personales puede ser ejercido por su representante legal. No obstante, el art. 11 del Real Decreto 1332/1994, de 20 de junio, sólo autoriza el acceso del representante legal del afectado cuando éste se encuentre en una situación de «minoría de edad que le imposibilite el ejercicio personal de los mismos» ${ }^{123}$. En la teoría general de los derechos cada vez se reconoce mayor capacidad de ejercicio de los derechos a los menores de edad, lo que limitaría el derecho de acceso de los padres ${ }^{124}$. De hecho, la Agencia Española de Protección de Datos ha

122 Esto, a veces, plantea la situación dramática de que los padres pagan la matrícula de sus hijos en las Universidades y éstos falsean sus calificaciones, no teniendo el padre forma de conocerlas sin el consentimiento del hijo. Una posible solución es supeditar el pago de la matrícula a los hijos mayores de edad a la autorización de éstos para que los padres puedan acceder a sus expedientes académicos.

123 Igualmente, la Instrucción 1/1998, de 19 de enero, antes citada, afirma que sólo podrá actuar el representante legal del afectado cuando éste se encuentre en situación de incapacidad o "minoría de edad que le imposibilite el ejercicio personal de los mismos, en cuyo caso será necesario que el representante legal acredite tal condición".

${ }^{124}$ La cuestión de la capacidad de los menores de edad para ejercitar los derechos de acceso, rectificación, cancelación y oposición tiene que analizarse a la luz de 
manifestado que el menor de edad puede acceder a sus ficheros, lo mismo que puede testar o contraer matrimonio. No obstante, una cosa es que los menores tengan un derecho de acceso a sus datos personales y otra cosa distinta es que no lo tengan los padres. La obligación de

la capacidad de obrar que a los menores de edad les atribuye el Código Civil. Inicialmente, el menor de edad no emancipado carece de capacidad de obrar, de manera que le corresponde su representación a las personas que ejerzan la patria potestad —art. 162 del Código Civil—o tutela —art. 267 del Código Civil—, y, en su caso, la intervención del curador - arts. 289 y 290 del Código Civil-. No obstante, el propio art. $1621 .^{\circ}$ del Código Civil exceptúa de la representación legal del titular de la patria potestad "[l]os actos relativos a derechos de la personalidad u otros que el hijo, de acuerdo con las leyes y con sus condiciones de madurez, puede realizar por sí mismo".

Nuestro ordenamiento jurídico diferencia esencialmente entre mayores de 14 años y mayores de 16 años. Los mayores de 14 años tienen reconocido en el Código Civil suficiente capacidad de discernimiento y madurez para adoptar por sí solos determinados actos de la vida civil, como por ejemplo, para la adquisición de la nacionalidad española por ejercicio del derecho de opción o por residencia, que efectúa el mayor de catorce años, asistido por representante legal —arts. 21.2.b) y 21.3.c) del Código Civil一; o para otorgar testamento —con la única excepción del testamento ológrafo-, previsto en el art. 663.1 del Código Civil. A partir de los 16 años, los menores aumentan su capacidad de obrar. Especial mención merece la emancipación del menor, que puede producirse a partir de los dieciséis años, y que "habilita al menor para regir su persona y bienes como si fuera mayor» - art. 323 del Código Civil- o para contratar la prestación de su trabajo, siempre que vivan de forma independiente,-art. 7.b) del Estatuto de los Trabajadores-. Respecto a los menores de catorce años, el ordenamiento jurídico permite en muchas ocasiones cierto ejercicio de derechos. El art. 154 del Código Civil señala que los padres ejercerán la patria potestad siempre en beneficio de los hijos, de acuerdo con su personalidad, y «si los hijos tuvieren suficiente juicio deberán ser oídos siempre antes de adoptar decisiones que les afecten". Así, las medidas judiciales sobre el cuidado y educación de los hijos en casos de separación, nulidad y divorcio son adoptadas "tras oírles si tuvieren suficiente juicio y siempre a los mayores de doce años" -art. 92 del Código Civil-. En la adopción, los mayores de doce años deben dar su consentimiento para ser adoptados en presencia del juez —art. 177 del Código Civil-. Cfr. M. Albaladejo, Derecho civil l-1; L. Díez Picazo, Elementos de Derecho Civil, R. BeRCovitZ, Derecho de la persona, Madrid, 1976.

La Dirección General de Registros y del Notariado ha señalado —Resolución de 3 de marzo de 1989- que no existe una norma que, de modo expreso, declarare la incapacidad de los menores para actuar validamente en el orden civil. En esta misma dirección, la Ley 30/1992, de 26 de noviembre, de Régimen Jurídico de las Administraciones Públicas y del Procedimiento Administrativo Común atribuye capacidad de obrar ante las Administraciones Públicas a "los menores de edad para el ejercicio y defensa de aquellos de sus derechos e intereses cuya actuación esté permitida por el ordenamiento jurídico administrativo sin la asistencia de la persona 
que los padres solicitaran el consentimiento de los hijos menores para acceder a sus datos académicos podría dificultar la tutela de los padres en la vigilancia de la educación de sus hijos. No se puede olvidar que la educación primaria y la secundaria son obligatorias hasta los dieciséis años -art. 27 CE-.

que ejerza la patria potestad, tutela o curatela». Sólo se exceptúa "el supuesto de los menores incapacitados, cuando la extensión de la incapacitación afecte al ejercicio y defensa de los derechos o intereses de que se trate». Cfr. J. GonzÁlez PéreZ y F. GonzÁlez Navarro, Comentarios a la Ley de Régimen Jurídico de las Administraciones Públicas y Procedimiento Administrativo Común, I, 2. ${ }^{\circ}$ ed, Cívitas, Madrid, 1999, págs. 863-864. La Ley Orgánica 1/1996, de 15 de enero, de Protección Jurídica del Menor -art. 2- establece que "la mejor forma de garantizar social y jurídicamente la protección de la infancia es promover su autonomía como sujetos». El art. 2 LOPJM señala que "las limitaciones a la capacidad de obrar de los menores se interpretarán de forma restrictiva».

Se puede afirmar así que el ejercicio del derecho fundamental a la protección de datos personales de los menores recae en el propio menor. La LOPD no establece ninguna limitación concreta para el ejercicio del derecho fundamental por parte de los menores. Por tanto, no sólo el menor de edad es titular del derecho fundamental a la protección de datos personales, sino que puede ejercitarlo directamente siempre que no se encuentre en una situación de minoría de edad o incapacidad que le imposibilite el ejercicio personal del mismo. La frontera para el ejercicio del derecho no está en los dieciocho años sino en las circunstancias personales que concurran y que posibiliten o no el ejercicio personal de este derecho y que obligue a ejercerlo a través de un representante legal. La posibilidad de ejercitar el derecho fundamental a la protección de datos personales por parte del menor de edad capaz también se puede extraer implícitamente del art. 3.1 de la Ley Orgánica 1/1982, de 5 de mayo, de Protección Civil del Derecho al Honor, a la Intimidad Personal y Familiar y a la Propia Imagen, que establece que el consentimiento de los menores e incapaces en este ámbito "deberá prestarse por ellos mismos si sus condiciones de madurez lo permiten, de acuerdo con la legislación civil». La problemática del ejercicio de los derechos de protección de datos por parte de los menores ha sido una cuestión abordada en la Memoria de la Agencia Española de Protección de Datos. Establece como principio que los mayores de catorce años disponen de las condiciones de madurez precisas para dar su consentimiento informado, por si mismos, para el tratamiento de sus datos de carácter personal y para ejercitar el derecho de acceso, rectificación, cancelación y oposición. La Agencia de Protección de Datos señala que no puede ofrecerse una solución claramente favorable a la posibilidad de que los menores de catorce años puedan prestar el consentimiento al tratamiento de sus datos personales, por lo que la referencia deberá buscarse en el art. 162.1 del Código Civil, tomando en cuenta fundamentalmente sus condiciones de madurez. Cfr. la referencia que se hace al consentimiento otorgado por menores de edad, dentro del estudio de las cuestiones más relevantes planteadas por los responsables de ficheros o tratamientos, Memoria de la Agencia Española de Protección de Datos 2000 págs.

381-383.

(C) UNED. Revista de Derecho Político 
En lo relativo al acceso a los datos personales que obran en los expedientes académicos existe no sólo la regulación del derecho de acceso a los tratamientos de datos personales del art. 15 LOPD sino también el derecho de acceso a archivos y registros administrativos del art. 105 b) CE. Como hemos indicado anteriormente, la Directiva 95/46/CE y la LOPD han incluido dentro del ámbito de protección todos los tratamientos de datos personales tanto informatizados como en soporte papel. De esta forma, no siempre existe una diferencia clara entre el derecho de acceso a un fichero de datos personales y el derecho de acceso a archivos y registros administrativos, cuando éstos están alfabetizados. Inicialmente, en caso de conflicto en la aplicación de la normativa, habría que optar por aquella norma que otorgara un mayor nivel de protección. El derecho de acceso al expediente administrativo del art. 105.b) CE es menos restrictivo que el derecho de acceso a los tratamientos de datos personales de la LOPD y permitiría el acceso de los padres o de cualquier persona autorizada por el titular de los da$\operatorname{tos}^{125}$. Así, algunas Secretarías de las Facultades han reconocido al padre el interés legítimo a partir de la Ley 30/1992, de 26 de noviembre, para acceder al expediente de sus hijos por ser éste el que paga la matrícula. No parece una solución acertada ya que existe en este caso una legislación específica, la LOPD. Tampoco una petición de acceso al expediente con una autorización firmada del alumno y con fotocopia del DNI es un procedimiento seguro ya que los padres tienen acceso al DNI y pueden reproducir fácilmente la firma de sus hijos ${ }^{126}$. No hay que olvidar que cuando el padre pide el expediente de su hijo es sencillamente porque su hijo no se lo da. Estamos en presencia de situaciones potencialmente conflictivas ${ }^{127}$.

Otra de las dificultades que presenta esta coexistencia normativa en el derecho de acceso al expediente es el cobro de una tasa por la certificación del expediente académico. El art. 15 LOPD establece que el interesado tendrá derecho a obtener gratuitamente información de sus datos de carácter personal sometidos a tratamiento ${ }^{128}$. Esta información

125 Art. 37 de la Ley 30/1992, de 26 de noviembre, de Régimen Jurídico de las Administraciones Públicas y del Procedimiento Administrativo Común.

126 Para evitarlo, la representación debidamente acreditada podría entenderse sólo ante funcionario público o notario.

127 El acceso de los padres a los expedientes de los hijos se complica aún más en supuestos de separación y divorcio, en los que uno de los cónyuges pasa pensión por alimentos o paga los estudios del hijo —o del otro cónyuge-que no estudia.

${ }_{128}$ Aunque la LOPD ha optado porque el derecho de acceso sea gratuito, la Directiva admitía que se pudiera cobrar una contraprestación. 
puede ser obtenida también mediante copia o fotocopia, certificada o no. No obstante, la certificación académica que expiden las Secretarías de las Universidades representa más que el derecho de acceso. Mientras que el derecho de acceso puede realizarse mediante cualquier forma, incluida la visualización, la certificación académica implica una fe pública, lo que justificaría el abono de unas tasas.

c) La gestión de la matriculación a través de entidades financieras. La emisión del carné del estudiante junto con tarjetas de crédito o débito

Las Universidades realizan el proceso de matriculación de alumnos y el pago de las nóminas de su personal a través de entidades financieras. El pago de la matrícula a través de una entidad financiera obliga a dar muchos datos de carácter personal. En el pasado, la propia entidad financiera se quedaba con una copia de la matrícula. Es necesario que en el proceso de matriculación, que implica un tratamiento de datos personales, se respeten los principios y los derechos de los afectados. Así, hay que garantizar especialmente el principio de calidad en el tratamiento de los datos que se exijan para este proceso de matriculación. Sólo pueden recogerse los datos que sean adecuados, pertinentes y no excesivos en relación con la finalidad de la matriculación —art. 4 LOPD-. Además, es necesario que se revelen los menores datos posibles a la entidad financiera.

La entidad financiera tiene el carácter de encargada del tratamiento, al ser la persona jurídica que trata los datos personales por cuenta del responsable del fichero - art. 3.g) LOPD-, que sería la Universidad. Así, no se considera comunicación de datos "el acceso de un tercero a los datos cuando dicho acceso sea necesario para la prestación de un servicio al responsable del tratamiento - art. 12.1 LOPDAhora bien, para que la entidad financiera tenga el carácter de encargado del tratamiento, es imprescindible que exista un contrato por escrito o a través de cualquier forma que pueda acreditarse su celebración que establezca que la entidad financiera sólo tratará los datos conforme a las instrucciones de la Universidad, que no los utilizará para un fin distinto, que no los cederá a un tercero, que implantará las medidas de seguridad y que, una vez cumplida la prestación contractual, devolverá a la Universidad o destruirá los datos personales, al igual que cualquier soporte o documentos en que conste cualquier dato de carácter personal. Así, si la entidad financiera quiere tratar los datos personales para otros fines - por ejemplo, comerciales, para convertir al alumno en cliente del banco- tiene que pedir el consentimiento del interesado ${ }^{129}$. Si la entidad financiera destina los datos 
para otra finalidad o los comunica a un tercero, será considerada responsable del tratamiento a los efectos de las infracciones de la LOPD.

No obstante, podría entenderse que en el pago de la matrícula a través de una entidad financiera ésta no sería encargada del tratamiento sino la responsable del fichero. Cuando el alumno está haciendo unos pagos a través de una entidad financiera, de alguna manera está consintiendo en el tratamiento de los datos. O si lo hace a través de la Universidad, poniendo la cuenta corriente de una entidad financiera para que le carguen la matrícula, se puede entender que autoriza la cesión -art. 11.2.c) LOPD - que se produciría en la medida en que el tratamiento responde a la libre y legítima aceptación de una relación jurídica cuyo desarrollo, cumplimiento y control implica necesariamente la conexión de dicho tratamiento con ficheros de terceros. En todo caso, la entidad financiera no podrá destinar los datos personales para una finalidad distinta de la matriculación, salvo que exista un consentimiento informado del interesado que admita el tratamiento de los datos para otra finalidad.

Otro supuesto diferente consistiría en encargar a las entidades financieras la edición del carné del estudiante. Estas serían encargadas del tratamiento por cuenta del responsable del fichero que sería la Universidad. Esto es legítimo con las exigencias mencionadas anteriormente. Ahora bien, si la entidad financiera quiere vincular el carné del estudiante con una tarjeta de crédito o de débito, tiene que pedir el consentimiento del interesado. Si esto no se hace, se vulnera el principio de calidad - art. 4 LOPD—, al tratar los datos para una finalidad distinta sin disponer del consentimiento ${ }^{130}$.

\section{d) La cesión de datos del censo electoral a las candidaturas en los procesos electorales universitarios}

Nos corresponde analizar ahora si es legítima la cesión de datos personales de los electores - nombre, apellidos y domicilio- de los ficheros de la Universidad a las candidaturas que se presentan en los procesos electorales que se desarrollan en las Universidades.

129 Así, suele existir una casilla donde se pide autorización a los alumnos para destinar los datos a una finalidad distinta.

130 Así, la Universidad de Zaragoza emitió el carné del estudiante junto con una tarjeta de crédito. La entidad financiera como encargada del tratamiento trató los datos para una finalidad distinta. Se cometió una infracción administrativa por parte de la Universidad, que lo había autorizado. 
Como ya hemos señalado, la LOPD exige el principio de consentimiento, tanto para el tratamiento de los datos - art. 6 LOPD - como para su cesión a terceras personas - art. 11 LOPD-. De esta forma, se garantiza el derecho a la autodeterminación informativa como derecho al control que toda persona tiene sobre sus datos de carácter personal, que conlleva saber quién los tiene y para qué los va a usar. Si las candidaturas electorales son consideradas un tercero distinto del responsable del fichero y del interesado estaríamos hablando de una cesión de datos. El art. 11.1 LOPD establece que "los datos de carácter personal objeto de tratamiento sólo podrán ser comunicados a un tercero para el cumplimiento de fines directamente relacionados con las funciones legítimas del cedente y del cesionario con el previo consentimiento del interesado". No obstante, esta regla general del consentimiento no es absoluta, existiendo una serie de excepciones, entre ellas que una norma con rango de ley regule previsiones concretas de cesión de datos sin consentimiento de los afectados. También puede entenderse que las candidaturas electorales no tienen el carácter de tercero sino que forman parte de la propia comunidad universitaria. Correspondería entonces determinar la legitimidad de este acceso a partir de la existencia de un fichero declarado del censo electoral, de las finalidades establecidas y de los datos registrados. La problemática se trasladaría desde la cesión de datos - art. 11 LOPD - al principio de calidad -art. 4 LOPD-. Sería necesario determinar si el tratamiento de los datos por las candidaturas electorales entra dentro de la finalidad legítima del fichero.

En relación con el procedimiento de elección del Rector, el art. 20 de la Ley Orgánica 6/2001, de 21 de diciembre, de Universidades establece que el Rector "será elegido por la comunidad universitaria, mediante elección directa y sufragio universal, libre y secreto, entre funcionarios del cuerpo de Catedráticos de Universidad, en activo, que presten servicios en ésta. Será nombrado por el órgano correspondiente de la Comunidad Autónoma. Los Estatutos regularán el procedimiento para su elección, la duración de su mandato y los supuestos de su sustitución en caso de vacante, ausencia o enfermedad".

Esta Ley no habilita legalmente la cesión de datos a las candidaturas electorales. En realidad, cuando se aprueban las Leyes, no siempre se prevén las posibles cesiones de datos ${ }^{131}$. Los Estatutos de cada Uni-

127 Esto no fue tenido en cuenta por el Tribunal Constitucional en la Sentencia 292/2000, de 30 de noviembre. Como posible solución, el Gobierno de Castilla la Mancha se ha planteado la aprobación de un Anteproyecto de Ley sobre cesiones de datos personales. 
versidad deben regular el procedimiento para la elección del Rector. Así, sobre esta cuestión, los Estatutos de la Universidad Complutense sólo dicen que "cada candidato a Rector deberá presentar un programa electoral a la Junta Electoral Central y podrá proponer el nombramiento de un interventor por cada uno de los colegios y mesas" - art. 76.3 de los Estatutos de la Universidad Complutense-. Igualmente, el art. $39.2 b)$ de los Estatutos establece que el Claustro aprobará el reglamento electoral. El Reglamento electoral de la Universidad Complutense de Madrid, de 4 de noviembre de 1993, regula el Censo electoral en los arts. 10-13, estableciendo que para el ejercicio del derecho de sufragio activo es necesaria la inclusión en el censo electoral. En lo procesos electorales en la Universidad Complutense existe un Colegio único, cuya elaboración compete a la Secretaría General bajo la inspección de la Junta Electoral Central -art. 12-. Las listas del censo serán expuestas públicamente en las Facultades y Escuelas con quince días de antelación a la celebración de las votaciones con el objeto de que se pueda conocer la inclusión en el censo y plantear el correspondiente recurso por inclusión o por omisión indebida —art. 13-.

El Acuerdo del Consejo de Gobierno de la Universidad Complutense, de 4 de abril de 2003, por el que se aprueban las normas de procedimiento para el desarrollo del proceso electoral al cargo de Rector, afirma, en relación a la publicidad del proceso electoral, lo siguiente: "La publicación oficial de las actuaciones electorales se hará en el Rectorado, como sede de la Administración Electoral. Y con el objeto de garantizar la máxima publicidad, dichas actuaciones deberán publicarse en los tablones de anuncios de todas las Facultades, Escuelas Universitarias y Centros Adscritos y en la página Web de la Universidad, a excepción, en este último caso, del contenido de los censos." La Universidad pone a disposición de cada candidato un espacio en la Web institucional, facilitando el envío de correos electrónicos a los electores, determinándose por la Junta Electoral Central el número de mensajes y su tamaño.

A la hora de establecer si puede cederse a las candidaturas el dato del domicilio de cada elector, hay que analizar si ese dato forma parte del censo electoral y si el censo electoral puede estar a disposición de cada una de las candidaturas. La regulación de la Universidad Complutense no dice nada acerca de los datos que deben formar parte del censo electoral. Tampoco se habilita la cesión del censo electoral a las candidaturas. En cambio, el Reglamento Electoral de la Universidad de Cádiz prevé en su art. 6 que en el censo electoral se hará constar, por cada elector, el número de documento nacional de identidad, nombre y apellidos, grupo de la comunidad universitaria al que pertenece 
y mesa electoral en la que está asignado, no incluyéndose el dato del domicilio.

Por una parte, la inclusión del dato del domicilio en el censo electoral para la celebración de elecciones a Rector puede parecer un dato excesivo, ya que dicho dato es a primera vista poco relevante para la finalidad que se persigue de garantizar el derecho a voto de cada elector en su mesa correspondiente y evitar duplicidades. Pero, por otra parte, el dato del domicilio puede ser necesario para facilitar la participación y el conocimiento de las candidaturas; especialmente cuando los procesos electorales se desarrollan en períodos no lectivos. De hecho, la participación en las elecciones universitarias es muy baja en comparación con otros procesos electivos. La elección democrática de los órganos de gobierno de las Universidades es una parte esencial de la autonomía universitaria, del derecho a la educación que implica la participación en el gobierno de las Universidades - art. 27 CE y del derecho de participación de los ciudadanos en la Administración Pública -art. 105 CE-. El derecho a la autodeterminación informativa no puede configurarse de tal forma que suprima o haga muy difícil el ejercicio de otros derechos fundamentales, especialmente aquellos de carácter procedimental, que facilitan la apertura y los cambios políticos ${ }^{132}$.

Por tanto, la necesidad de hacer compatible el derecho a la autodeterminación informativa con el ejercicio de otros derechos fundamentales puede justificar la cesión de datos del censo electoral a las candidaturas. No hay que olvidar que en los procesos electorales de carácter político, la Ley Orgánica 5/1985, de 19 de junio, Reguladora del Régimen Electoral General prevé la cesión del censo electoral a las candidaturas. Esta Ley debe ser considerada de aplicación supletoria en todos los procesos electorales de órganos estatales. La Ley Orgánica 11/1985, de 2 de agosto, de Libertad Sindical para las elecciones sindicales, prevé la cesión de datos del censo a las candidaturas, aunque en este censo no esta el domicilio sino sólo el puesto de trabajo. Las candidaturas universitarias estarían obligadas por el deber de secreto y confidencialidad y una posible vulneración de este deber podría dar lugar a un ilícito penal de los arts. 197 y siguientes del Código Penal, una vulneración del derecho a la intimidad de la Ley Orgánica 1/1982, de 5

132 Cfr. J. H. Ely, Democracy and Distrust. A Theory of Judicial Review, Harvard University Press, 1980, págs. 43-72; A. Troncoso ReIGADA, "Método jurídico, interpretación constitucional y principio democrático", en E. EsPíN TEMPLADO y F. J. DíAZ REVORIO, La justicia constitucional en el Estado democrático, Tirant lo blanch, Valencia, 2000, págs. 432-440. 
de mayo, de protección civil del derecho al honor, a la intimidad personal y familiar y a la propia imagen, y una infracción a la legislación específica de protección de datos.

La decisión le corresponde a cada Universidad, con la aprobación de su normativa propia que lo prevea. Una solución intermedia es que la propia Universidad lleve a cabo el encarte y envío de la publicidad de las diferentes candidaturas, sin necesidad de ceder los datos de los domicilios a terceras personas. Esta utilización de los diferentes ficheros de la Universidad estaría habilitada por las propias funciones del Rector - por ejemplo, art. 65 y ss de los Estatutos de la Universidad Complutense- de informar a la Comunidad Universitaria sobre la celebración de unas elecciones universitarias ${ }^{133}$. La cesión de un espacio en la página Web de cada Universidad para publicar el programa electoral y las facilidades que dé la Universidad para que a través del administrador del correo las candidaturas puedan enviar correos electrónicos a los electores son instrumentos que las nuevas tecnologías ofrecen para facilitar la participación y la información de los electores, reduciendo al máximo los posibles riesgos al derecho a la vida privada ${ }^{134}$. Estos ficheros relativos al censo electoral deberían estar controlados no por las Secretarías Generales sino por la propia Junta Electoral, para garantizar la igualdad de medios y la imparcialidad del proceso, de la misma forma que la Junta Electoral Central lo hace con los espacios electorales en las elecciones generales, autonómicas y locales.

\section{Resumen}

La implantación de modernos sistemas de información en las Universidades ha mejorado el servicio público pero también ha aumentado la preocupación de estudiantes y profesores por el uso de su información personal. Existe la percepción de que los tratamientos abusivos de datos personales menoscaban una parte importante de nuestra vida. No se trata de limitar la utilización de las tecnologías de la información y de las comunicaciones por parte de las Universidades sino de hacer compatible el desarrollo de la informática con los derechos de los ciudadanos. Con el cumplimiento de la legislación de protección de datos las Universidades pueden alcanzar un equilibrio que permita aprove-

133 Este sistema tendría otros beneficios como favorecer la igualdad del proceso electoral sin hacerlo depender de la capacidad económica de cada una de las candidaturas para enviar mailings propios.

134 Por ejemplo, todas las candidaturas podrían enviar 5 mensajes, y con clic un interesado podría incluirse en una lista de distribución. 
char la informática en la gestión universitaria sin menoscabar los derechos de las personas. Un ejemplo de tratamiento de datos personales que se produce en el ámbito universitario es el derivado de las encuestas académicas de los profesores No es necesario el consentimiento del profesor para el tratamiento de sus datos ya que éste se produce en relación a las partes de una relación laboral o administrativa. No obstante, hay que prestar especial atención a quién va a tener acceso a los resultados de las mismas.

Las Universidades públicas y privadas tienen un régimen jurídico distinto. Le es de aplicación a todos los ficheros de las Universidades públicas la regulación específica relativa a los ficheros públicos prevista en la LOPD. Así, es posible la comunicación de datos entre la Universidad Pública y la Administración sin consentimiento del interesado para el ejercicio de las mismas competencias.

Una cuestión específica es la publicación de determinados actos administrativos que afectan a profesores y alumnos. La regla general en los procedimientos selectivos o de concurrencia competitiva es la publicación de la resolución. Esta publicación cumple dos funciones: notificación a una pluralidad abierta de interesados y garantía del principio de transparencia administrativa. El procedimiento autonómico de concesión del complemento retributivo es, en el supuesto estudiado en este artículo, de concurrencia competitiva. Por ello, es legítimo publicar la resolución del procedimiento en tablones de anuncios, en boletines oficiales y en páginas web. Ahora bien, es muy importante determinar el contenido de la publicación. La habilitación legal para la publicación afecta sólo a la resolución, que debe ser entendida como el resultado final —nombre y apellidos y puntos totales-y no a todos los criterios o requisitos necesarios para alcanzar la resolución. La evaluación de la actividad investigadora por el Ministerio a través de la concesión de sexenios no es un procedimiento selectivo ni de concurrencia competitiva ya que no hay un número limitado de tramos a atribuir, por lo que no rige el principio de publicidad sino el de confidencialidad de los datos personales. El procedimiento de habilitación del profesorado establecido en la LOU, así como los procedimientos de acceso a la función pública, son selectivos por lo que rige el principio de publicidad. Sin embargo, todo este planteamiento se verá afectado por la modificación de la LOU —se incorpora en período de pruebas el análisis de la enmienda del Senado-.

La calificación de los alumnos no es un procedimiento de concurrencia competitiva. Por tanto, no hay una habilitación legal clara que prevea la publicidad de manera general y que permita una cesión de 
datos sin consentimiento. En todo caso también hay que valorar la posibilidad de que la publicación de las calificaciones de alumnos en tablones no infrinja el derecho fundamental a la protección de datos, en virtud del principio de transparencia administrativa y del derecho a la educación, que pueden aconsejar que aquellos que tengan un interés legítimo puedan acceder a las calificaciones del grupo. La existencia de una relación jurídica del alumno con la Universidad así como los propios Estatutos de las Universidades pueden justificar la aceptación de una forma determinada de publicación de notas en tablones de anuncios. Todo ello puede permitir la publicación de las calificaciones en tablones de anuncios en recintos universitarios con acceso restringido para profesores y alumnos — no para terceras personas-. No es legítima la publicación de las calificaciones de los alumnos a través de Internet, a menos que se habiliten procedimientos que garanticen el derecho a la confidencialidad de la información. Este planteamiento también se verá afectado por la reforma de la LOU.

Es legítima la publicación del directorio telefónico y de correo electrónico de profesores en la intranet de la Universidad sin consentimiento de éstos ya que se refiere a las partes de una relación administrativa o laboral, siendo esta publicación necesaria para la comunicación intrauniversitaria. En todo caso, siempre habrá que respetar el principio de calidad y la finalidad del fichero.

\title{
Palabras clave
}

- Protección de datos personales en Universidades

- Publicación de datos de profesores

- Publicación de datos de alumnos

- Principio de publicidad

- Comunicación de datos a las Universidades

Title:

"Publication of lectures and students personal data and personal privacy. the protection of personal data in the university".

\begin{abstract}
The implementation of modern information systems in the University has improved the public service but, at the same time, has in-
\end{abstract}


creased the concern of students and lecturers as regards the use of their personal information. They perceive that the abusive processing of personal data impinge upon an important part of their lifes. It is not the case of limiting the use of the information and communication technologies by Universities but to make it compatible with citizens' rights. Complying with data protection legislation, Universities can strike the balance between the advantage of the use of information technologies in the University management and people's rights. An example of the processing of personal data in the university area it the one that comes from the lecturers' academic surveys. Consent of the lecturer is not necessary for the processing of his or her data as this happens by virtue of working or administrative relationship. Nevertheless, it is very important to take care about who is having access to their results.

Public and private universities have a different legal regime. The files of the public Universities must comply with the specific regulation established by the Spanish Data Protection Act (LOPD) for public files. Thus, it is possible the communication of personal data between the Public Universities and the Public Administration without the consent of the data subject for the exercise of the same competences.

A specific question is the publication of some administrative acts that affect to lecturers and students. The general rule for selective or competitive procedures is the publication of the resolution. This publication fulfils two functions: notification to a plurality of interested persons and the guarantee of the principle of administrative transparency. The regional procedure for the granting of the additional salary is, in the case dealt with by this paper, a competitive procedure. Thus, it is legitimate to publish the resolution of the procedure on the notice boards, in official journals and in Web pages. However, it is very important to determine the content of the publication. The legal basis for the publication affects only to the resolution which must be understood as the final result - first name, last name and total score - and not to all the criteria or requirements needed for taking the final decision. The evaluation by the Ministry of the investigations through the awarding of six-year periods it is not a selective or competitive procedure as there is not a limited number of terms for assignment and, thus, it is not governed by the publicity principle but, instead, for the principle of confidentiality of personal data. The accreditation procedure established by the Organic Law of Universities (LOU) as well as the processes for access to the public function, are selective and, thus, governed by the publicity principle. 
Attributing marks to the students is not a competition procedure. So that, there is not a clear legal basis that foresees publicity in a general manner and allows the communication of data without the need for consent. In any case, there is also a need to assess the possibility that the publication of students' marks on notice boards does not infringe upon the fundamental right to data protection by application of the principle of administrative transparency and the right to education, that may advice in favour that those with a legitimate interest could access to the marks of the members of the group. The existence of a legal relationship between the student and the University as well as the specific Statutes of every University can justify the acceptance of a given way of publication of marks on notice boards. It may allow the publication of marks on notice boards inside University premises with restricted access for lecturers and students - and no for third parties-. It shall not be legitimate the publication of students' marks on the Internet unless measures to safeguard the right to the confidentiality of the information are put in place.

It is legitimate the publication of lecturers telephone directory as well as their e-mail addresses on the University intranet without their consent as there is an administrative relationship between them and the University and this publication it is necessary for the communication among the members of the University community. In any case, the quality and purpose limitation principles must be respected.

\section{Keywords}

- Protection of personal data in Universities

- Publication of lecturers' data

- Publication of students' data

- Publicity principle

- Communication of data to Universities

\section{Sumary}

1. UNIVERSITIES FROM A CONSTITUTIONAL PERSPECTIVE. 2. THE PROTECTION OF PERSONAL DATA IN THE UNIVERSITIES. a) The information technologies and the processing of personal data in the Universities. The Universities and the legislation of personal data protection. b) The identification of the processing of personal data and the notification of files of the Universities. c) The data protection principles 
and rights applied to Universities. The Public Universities files as pubic files and their specific regulation. The example of academic surveys. d) The communication of data from Universities to Public Administrations - to the Police- and to private companies. The communication of data to the Universities for investigation purposes. e) The application of the regulation on personal data protection to University manual files. f) The competent control authority for the supervision of the processing of personal data by the Universities. 3. THE PUBLICATION OF LECTURERS' DATA a) The publication of lecturers' data regarding the payment of additional salaries by the Autonomous Communities. The publication of data regarding proceedings for the assessment of the investigation activities, the authorisation, accreditation and access to the public function by lecturers. b) The publication of lecturers telephone directories and e-mail addresses. 4. THE PUBLICATION AND COMMUNICATION OF STUDENTS' DATA a) The publication of students' marks on notice boards and websites. b) The right to confidentiality of students' personal data and the parents' right of access to their sons' academic files. The payment of fees for the certification of academic reports. c) The management of enrolment through financial entities. The issuing of student cards together with credit or debit cards. d) The communication of data from the electoral roll to the candidates in the University electoral processes. 